UNIVERSIDADE DE BRASÍLIA

INSTITUTO DE RELAÇÕES INTERNACIONAIS

FELIPE RICARDO BAPTISTA E SILVA

\title{
GOVERNANÇA DE NOVAS DIMENSÕES DE SEGURANÇA INTERNACIONAL: DOENÇAS INFECCIOSAS EMERGENTES
}


FELIPE RICARDO BAPTISTA E SILVA

\title{
GOVERNANÇA DE NOVAS DIMENSÕES DE SEGURANÇA INTERNACIONAL: DOENÇAS INFECCIOSAS EMERGENTES
}

\begin{abstract}
Dissertação de mestrado apresentada como requisito parcial para obtenção do título de mestre em Relações Internacionais, área de concentração Política Internacional e Comparada, pelo Instituto de Relações Internacionais da Universidade de Brasília, elaborada por Felipe Ricardo Baptista e Silva, sob orientação do Professor-doutor Antônio Jorge Ramalho da Rocha.
\end{abstract}




\title{
GOVERNANÇA DE NOVAS DIMENSÕES DE SEGURANÇA INTERNACIONAL: DOENÇAS INFECCIOSAS EMERGENTES
}

\begin{abstract}
Dissertação de mestrado apresentada como requisito parcial para obtenção do título de mestre em Relações Internacionais, área de concentração Política Internacional e Comparada, pelo Instituto de Relações Internacionais da Universidade de Brasília, elaborada por Felipe Ricardo Baptista e Silva, sob orientação do Professor-doutor Antônio Jorge Ram alho da Rocha.
\end{abstract}

Aprovado em: _ I _ I

BANCA EXAMINADORA

Prof. Antônio Jorge Ramalho da Rocha (orientador)

Prof. ${ }^{a}$ Cristina Yumie Aoki Inoue

Prof. José Franscisco Nogueira Paranaguá de Santana 
Dedico esse trabalho a minha mãe, que me ensinou tudo que sei sobre o pensamento crítico e o gosto de estudar. 


\section{AGRADECIMENTOS}

Acredito que todas as pessoas - e os projetos que elas desenvolvem - são feitos essencialmente de ideias. Por isso, agradeço abaixo a todos aqueles que contribuíram para explorar as mais diferentes ideias ao longo desse mestrado - projeto meu que, em nenhum momento, se satisfez apenas no ato de estudar, pesquisar e redigir.

Ao meu companheiro, Victor Bueno - que provavelmente sabe tanto dos assuntos dessa dissertação quanto eu - pela paciência, pelo apoio incondicional, e por me ensinar tanto sobre muito, todos os dias ao meu lado;

Ao meu orientador, Professor Antônio Jorge Ramalho da Rocha, por ter tido a disponibilidade de me acompanhar nesse projeto, pelo compartilhamento de experiência e de ideias críticas fundamentais à formulação desse trabalho;

Ao meu outro orientador, José Paranaguá, pelo incentivo e por compartilhar comigo um pouco de sua experiência, o que tem sido fundamental para meu desenvolvimento nos últimos anos.

A toda a equipe do Núcleo de Estudos sobre Bioética e Diplomacia em Saúde - em especial a Roberta Campos e Alejandra Carrillo, colegas com as quais trocar ideias é sempre muito enriquecedor.

A toda minha família, em especial minha tia Mariela, que sei que está tão feliz e orgulhosa quanto eu pelo fim de mais essa etapa;

Aos meus melhores amigos que indubitavelmente fizeram parte do meu desenvolvimento intelectual - e, em especial, a Lyanna Carvalho, por incitar em mim a excitação acadêmica desde cedo;

E, por fim, aos meus queridos colegas da pós-graduação no IREL, cuja companhia nesses últimos dois anos fez com que eu aprendesse tanto. 
"What's the most resilient parasite? A bacteria? A virus? An intestinal worm? An idea. Resilient, highly contagious. Once an idea's taken hold in the brain it's almost impossible to eradicate." 


\section{RESUMO}

Esse estudo objetiva compreender de que forma se estrutura a governança de uma nova dimensão de segurança internacional: as doenças infecciosas emergentes (DIEs). Inicialmente, discute-se como o tema das doenças infecciosas - em geral - tem sido apresentado pela literatura acadêmica especializada como novos riscos à segurança internacional. A partir desse escrutínio, foi possível organizar as contribuiçõos de diversos autores sobre o tema, propondo cinco abordagens diferentes da relação entre doenças infecciosas e segurança internacional. A partir disso, averígua-se a maneira mais adequada para compreender a governança das DIEs com a análise das teorias de governança nos campos das Relações Internacionais e da "saúde global". Nesse contexto, e com essas ferramentas, mapeiam-se os atores e dispositivos internacionais que caracterizam a governança das doenças infecciosas, e, posteriormente a das DIEs. Do ponto de vista metodológico, essa dissertação adota o modelo analítico de Young (1999) e Fidler (2002) para analisar a principal peça jurídica desse regime, o Regulamento Sanitário Internacional, examinando sua evolução entre versões de 1969 e 2005 em seus componentes substantivos, processuais e de implementação. Essa análise inova ao apresentar, de um ângulo original, o desenvolvimento da governança internacional das DIEs nas últimas décadas.

Palavras-chave: doenças infecciosas emergentes; governança; segurança internacional. 


\begin{abstract}
This study aims to understand how is developed the governance of a new dimension of international security: emerging infectious diseases (EIDs). At first, we discuss how the topic of infectious disease - in general - have been presented by the academic literature as new risk to international security. From this analysis, it was possible to organize the contributions of various authors on the subject by proposing five different approaches to the relationship between infectious diseases and international security. After that, this study investigates the most appropriate way to understand the governance of EIDs analyzing theories of governance in the fields of International Relations and "global health." In this sense, and adopting these tools, it was possible to map actors and international devices that are involved in the governance of infectious diseases, and later in the EID. Methodologically, this dissertation adopts the analytical model of Young (1999) and Fidler (2002) to analyze the centerpiece of this regime, the International Health Regulations, tracing its development between its 1969 and 2005 versions. This analysis innovates for it presents, from an original point of view, the development of international governance of EIDs in recent decades.
\end{abstract}

Keywords: emerging infectious diseases; governance; international security. 


\section{LISTA DE ILUSTRAÇÕES}

Figura 1 - "Peste em uma cidade da antiguidade", por Michael Sweerts, 1654.

Figura 2 - " "A peste de Florença descrita por Boccaccio", autor desconhecido, 1348.

$\begin{array}{lll}\text { Figura } 3 \text { - } \quad \text { Esquema da dinâmica da governança em saúde global. } & \text { p.64 }\end{array}$

Figura 4 - Instrumento de decisão para avaliação e notificação dos eventos p.107 que possam constituir emergência de saúde pública de importância internacional.

Figura 5 - Autoridades implementadoras do RSI 2005 nos âmbitos p.115 doméstico e internacional.

Quadro 1 - Abordagens das doenças infecciosas como tema de segurança p.52 internacional.

Quadro 2 - Componentes de implementação: principais atores e suas p.112 atribuições no regime.

Quadro 3 - Síntese da análise dos regimes internacionais por componentes. $\quad$ p.117 


\section{LISTA DE ABREVIATURAS E SIGLAS}

BWC

CDC

CIA

CSR

DIEs

DIRs

DIs

DOD

DSSH

EPR

ESPII

FAO

GOARN

MCMs

OIE

OIs

$\mathrm{OMC}$

OMS

ONGs

ONU

PFN
Convenção sobre Armas Biológicas

Centers for Desease Control and Prevention (Estados Unidos da América)

Central Intelligence Agency (Estados Unidos da América)

Departamento de Vigilância e Resposta às Doenças

Comunicáveis (Organização Mundial da Saúde)

Doenças Infecciosas Emergentes

Doenças Infecciosas Reemergentes

Doenças Infecciosas

Departamento de Defesa (Estados Unidos da América)

Departamento de Saúde e Serviços Humanos (Estados Unidos da América)

Departamento de Alerta e Resposta às Epidemias e Pandemias (Organização Mundial da Saúde)

Emergência de Saúde Pública de Importância Internacional

Organização das Nações Unidas para a Alimentação e a Agricultura

Global Outbreak Alert and Response Network

"Medical countermeasures"

Organização Mundial de Saúde Animal

Organizações Internacionais

Organização Mundial do Comércio

Organização Mundial da Saúde

Organizações não-governamentais

Organização das Nações Unidas

Pontos Focais Nacionais 
PNUD

RSI

SARS

UE

UNAIDS

UNESCO

UNICEF

UNODC
Programa das Nações Unidas para o Desenvolvimento

Regulamento Sanitário Internacional

Síndrome Respiratória Aguda Grave

União Europeia

Programa Conjunto das Nações Unidas sobre HIV/AIDS

Organização das Nações Unidas para a educação, a ciência e a cultura

Fundo das Nações Unidas para a Infância

Escritório das Nações Unidas sobre Drogas e Crime 


\section{SUMÁRIO}

1 INTRODUÇÃO $\quad$ p.13

2 DOENÇAS INFECCIOSAS À LUZ DAS NARRATIVAS SOBRE p.20 SEGURANÇA INTERNACIONAL

$\begin{array}{llr}2.1 & \text { Abordagem tradicional p.21 }\end{array}$

2.1.1 Problematizando casos pertinentes à abordagem tradicional p.26

a) Campanhas de vacinação como instrumentos de promoção da p.26 segurança

b) Guerra biológica e bioterrorismo p.29

$\begin{array}{lll}2.2 & \text { Abordagens revisoras } & \text { p.35 }\end{array}$

$\begin{array}{ll}\text { 2.2.1 Abordagem securitizadora p.35 } & \text { p }\end{array}$

2.2.2 Abordagem da "health security" p.41

$\begin{array}{ll}\text { 2.2.3 Abordagem da segurança humana p.44 } & \text { p.4. }\end{array}$

$\begin{array}{lr}\text { 2.2.4 Abordagem crítico-sociológica } & \text { p.47 }\end{array}$

$\begin{array}{lll}2.3 & \text { Conclusão } & \text { p.51 }\end{array}$

3 COMO ANALISAR A GOVERNANÇA DAS DOENÇAS p.53 INFECCIOSAS EMERGENTES?

3.1 Breve revisão dos desenvolvimentos conceituais e teóricos sobre p.54 governança

3.1.1 Governança na perspectiva de Oran Young p.57

$\begin{array}{llr}3.2 & \text { Governança em saúde global p.59 }\end{array}$

3.3 Problematizando a aplicação dos modelos analíticos de governança na p.65 agenda de doenças infecciosas emergentes

3.3.1 Saúde global p.66

$\begin{array}{ll}\text { 3.3.2 Governança das doenças infecciosas } & \text { p.68 }\end{array}$

$\begin{array}{ll}\text { 3.3.3 Governança das doenças infecciosas emergentes } & \text { p.77 }\end{array}$

3.4 Conclusões: empregando modelos analíticos à análise empírica p.81 
4 GOVERNANÇA INTERNACIONAL DAS DOENÇAS

INFECCIOSAS EMERGENTES

4.1 Regulamento Sanitário Internacional (1969) p.88

$\begin{array}{lr}\text { 4.1.1 Componentes substantivos no RSI } 1969 & \text { p.89 }\end{array}$

a) Compartilhamento da informação epidemiológica p.89

b) Organização das capacidades de saúde e medidas sanitárias p.92

$\begin{array}{ll}\text { 4.1.2 Componentes de implementação no RSI } 1969 & \text { p.94 }\end{array}$

4.2 Ascenção da estratégia "global health security" p.95

$\begin{array}{llr}\text { 4.3 Regulamento Sanitário Internacional (2005) p.99 } & \text { p. }\end{array}$

$\begin{array}{ll}\text { 4.3.1 Componentes substantivos } & \text { p.99 }\end{array}$

a) Gestão de informações epidemiológicas $\quad$ p.100

b) Medidas de saúde e capacidades nacionais $\quad$ p.102

$\begin{array}{ll}\text { 4.3.2 Componentes processuais no RSI } 2005 & \text { p.106 }\end{array}$

4.3.3 Componentes de implementação no RSI $2005 \quad$ p.111

$\begin{array}{lll}4.4 & \text { Conclusões } & \text { p.116 }\end{array}$

5 CONCLUSÃO $\quad$ p.120

$\begin{array}{lr}\text { REFERENCIAS } & \text { p.124 }\end{array}$ 


\section{INTRODUÇÃO}

Durante a redação das últimas páginas dessa dissertação, uma epidemia do vírus ebola acomete o ocidente africano. Desde o aparecimento dos primeiros casos de ebola, na tríplice fronteira entre Libéria, Guiné e Serra Leoa, em março de 2014 (WORLD HEALTH ORGANIZATION, 2014a), a doença já se propagou para Senegal, Nigéria, Espanha e Estados Unidos, com um total de aproximadamente 4.500 casos, até meados de outubro. Esse número já é três vezes o total de casos registrados desde a descoberta do vírus, em 1976 (WORLD HEALTH ORGANIZATION, 2014b).

Antes reclusa em vilas no centro do continente, a doença agora se espalha por grandes centros urbanos com uma taxa de mortalidade superior a 50\%. A inexistência de cura, o desgaste psicossocial e econômico causado pelo vírus, a limitação de serviços e recursos suficientes para responder à epidemia, a vulnerabilidade das populações de todos os países em face da propagação internacional e o potencial pandêmico caso o vírus adquira propriedades de transmissão por via aérea evidenciam a relevância dessa doença em sua condição de ameaça à segurança internacional.

Assim como as guerras, as doenças infecciosas não são problemas novos para o homem. Como diz Camus (2012, p.37) em sua obra-prima, “A Peste”,

Todos sabem que as pestes são recorrentes no mundo e, todavia, é difícil acreditar quando elas se abatem sobre nós. Houve tantas pestes quantas guerras no mundo; e, ainda assim, pestes e guerras sempre pegam as pessoas igualmente de surpresa. ${ }^{1}$

Tucídides (2009), em seu relato sobre a Guerra do Peloponeso, registra observações lúgubres sobre a epidemia - cuja causa foi posteriormente identificada como febre tifoide que levou a morte cerca de um terço da população de Atenas, em 430 a.C.

[...]os corpos dos homens moribundos estirados uns sobre os outros, e as criaturas meio mortas cambaleiam pelas ruas e se reúnem em volta das fontes em seu anseio por água. Os lugares sagrados em que se haviam alojado também estavam cheios de cadáveres de pessoas que morreram ali [...]; quando o desastre superou todos os limites, os homens, sem saber o que viriam a ser, tornaram-se totalmente negligentes com tudo, seja sagrado ou profano.

\footnotetext{
${ }^{1}$ Tradução livre do autor.
} 
Figura 1 - "Peste em uma cidade da antiguidade", por Michael Sweerts, 1654.

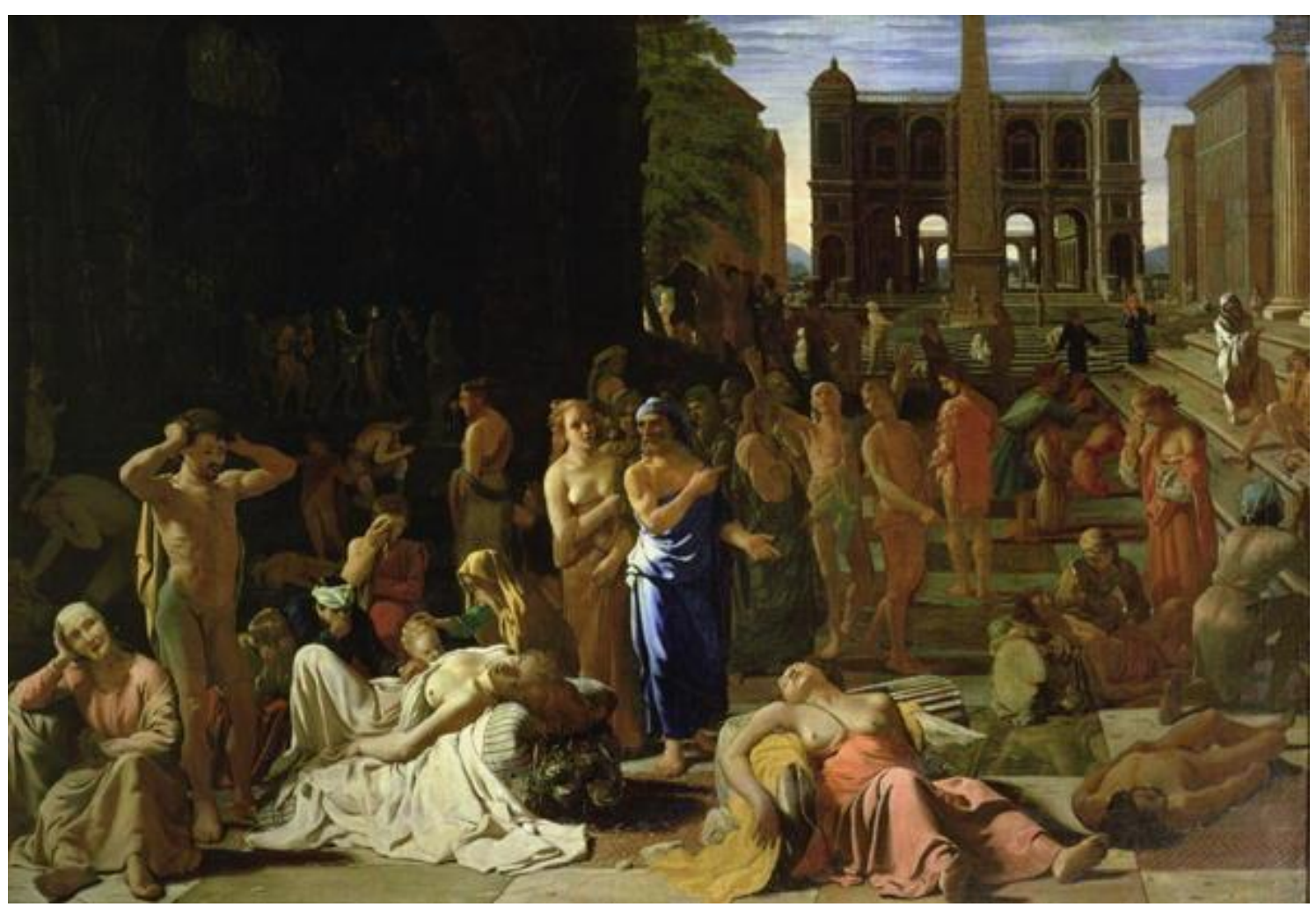

Fonte: LACMA. Disponível em: http://collections.lacma.org/node/183358

No século XIV, no auge do renascimento, a urbanização crescente, aliada a outros fatores, compôs o cenário para o surgimento de uma das mais desastrosas epidemias já registradas: a peste bubônica, também conhecida como peste negra. Estima-se que a doença tenha matado cerca de 50 milhões de pessoas (MORENS et al., 2008). Boccaccio (1872, p.2940) comenta sobre a desestabilização social trazida pela peste negra que se alastrou na cidade mais rica da Europa Ocidental, Florença, em 1348:

[...] à época, a aflição do povo era tamanha que as leis, humanas e divinas, não mais valiam. [...] pois o terror era tamanho que um irmão tinha fugido de seu irmão, a esposa de seu marido, e, o que é mais raro, um pai de seu próprio filho.”

Oh, habitações magníficas e palácios nobres que foram então despovoados ao último habitante! Oh, quantas famílias se tornaram extintas! Que riqueza e vastas possessões foram deixadas e nenhum herdeiro conhecido para herdá-las! Oh, os números de ambos os sexos, no auge do vigor da juventude tomaram o café-damanhã de manhã com seus amigos vivos, e jantaram à noite com seus amigos falecidos no outro mundo! ${ }^{2}$

\footnotetext{
${ }^{2}$ Tradução livre do autor.
} 
Figura 2 - "A peste de Florença descrita por Boccaccio", autor desconhecido, 1348.

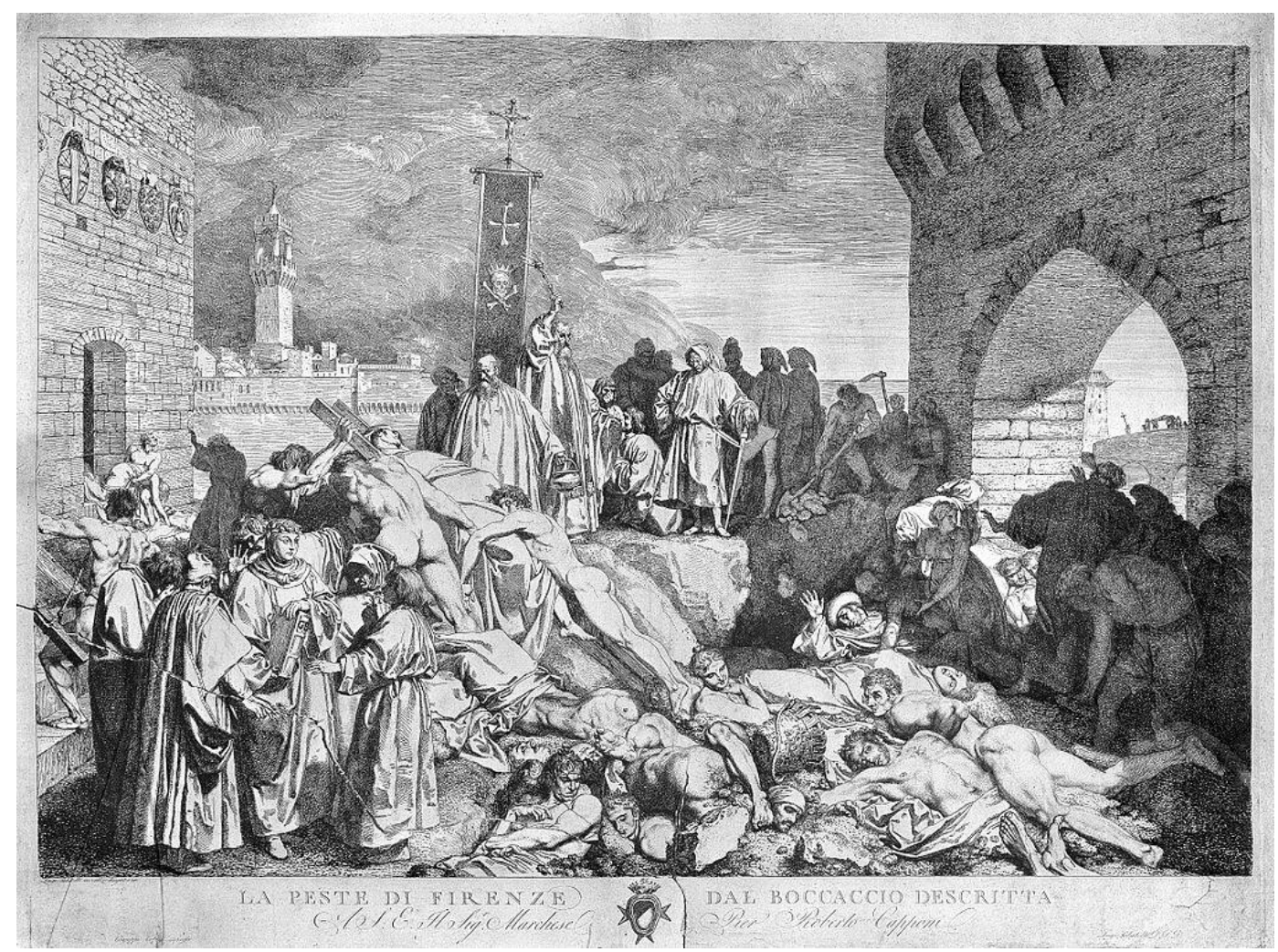

Fonte: WIKIMEDIA COMMONS. Disponível em: http://goo.gl/hyk3YS

$\mathrm{Na}$ contemporaneidade, as epidemias de doenças infecciosas adquiriram importância internacional. Dois casos recentes exemplificam isso. Em 2003, a Síndrome Respiratória Aguda Grave (SARS), uma nova doença causada por uma cepa específica do coronavírus, de origem animal, causou a primeira crise de saúde pública internacional neste século (FIDLER, 2003b). No curto intervalo entre novembro de 2002 e julho de 2003, a OMS registrou a ocorrência de 8.096 casos e 774 mortes causadas pelo vírus (WORLD HEALTH ORGANIZATION, 2014c). Em maio de 2003, a Organização Mundial da Saúde, em resolução, reconheceu que a SARS é "a primeira doença infecciosa severa a emergir no século XXI" e que ela "coloca uma séria ameaça à segurança da saúde global, às populações, ao funcionamento dos sistemas de saúde e à estabilidade e crescimento das economias" (WORLD HEALTH ORGANIZATION, 2003e).

Em março de 2009, uma variação sazonal do vírus causador da gripe suína acometendo seres-humanos - Influenza A (H1N1) - ocasionou a primeira pandemia do século XXI. Em maio daquele mesmo ano, a doença já havia se espalhado por pelo menos 46 países, gerando aproximadamente 13.000 casos, além de diversos outros suspeitos (WORLD 
HEALTH ORGANIZATION, 2014d). A rápida propagação da cepa A (H1N1) no intervalo de poucos meses colocou a comunidade internacional em alerta, demandando intensa concertação em escala global de países e instituições responsáveis pelo tema. $\mathrm{O}$ incidente serviu como um teste para os dispositivos normativos, mecanismos institucionais e procedimentos existentes e conformados no bojo da governança das doenças infecciosas.

O fenômeno da propagação internacional de doenças infecciosas, especialmente daquelas ainda desconhecidas, configura o que David Held (2000) chama de "boundary problems" $"$. Segundo o autor, essa nova dimensão de problemas desafia as distinções entre a política doméstica e a internacional, entre os problemas internos e externos e, também, entre as preocupações relativas à soberania do Estado-Nação e à inserção internacional. O crescimento na ocorrência e impacto dessa classe de problemas dá origem, segundo Held, às "overlapping communities of fate", definidas como "o estado das coisas em que o destino e as perspectivas de comunidades políticas individuais estão cada vez mais atrelados" (HELD, 2000, p.400).

Duas consequências importantes advêm dessas considerações. A primeira delas é abordada pelos defensores da vertente "transformacionista" dos impactos da globalização na política internacional (HELD et al., 2000). Essa perspectiva defende que o processo de globalização exige que os Estados, para se adequarem à nova ordem do mundo contemporâneo, transformem e adaptem suas estruturas de autoridade, suas instituições e os procedimentos que empregam nesse campo. Essa transformação acarreta, consequentemente, na nova forma em que se organizam e desenvolvem as relações internacionais para responder a esses desafios.

A segunda consequência consiste na identificação de novas dimensões de segurança internacional. Essas novas dimensões, ditas "não-tradicionais", são aquelas que superam as ameaças ligadas às questões militares e de conflito entre Estados. Ao representarem riscos para a estabilidade político-econômica das sociedades e para a saúde das populações, as doenças infecciosas são fenômenos que ilustram essa definição.

Vale esclarecer que o emprego feito da expressão "novas dimensões" não significa que as doenças infecciosas sejam riscos novos, recentes ou atuais à segurança. Como evidencia a própria história da saúde pública no mundo, as doenças infecciosas são desafios persistentes

\footnotetext{
3 "problemas de fronteira", tradução livre.

4 “comunidades de destino compartilhado", tradução livre.
} 
para países. Por isso, "novas" são, na verdade, as teorias e abordagens acadêmicas que procuram entender porque as doenças infecciosas são um tema de segurança ${ }^{5}$.

Esta dissertação oferece uma análise de como a comunidade internacional, no curso do processo transformador da globalização, tem se organizado para lidar com novas dimensões de segurança internacional. Isso será feito analisando um exemplo específico dessa noção não-tradicional de segurança: as doenças infecciosas emergentes (DIEs), que são as novas doenças infecciosas $^{6}$. Exemplos de DIEs são SARS e Influenza A (H1N1). O interesse especial por essa classe específica de doenças deve-se ao seu potencial epidêmico e pandêmico que enseja o caráter de urgência corroborando a dimensão de segurança associada a ela.

Nesse sentido, o objetivo dessa pesquisa é compreender como se desenvolveu a governança internacional das doenças infecciosas emergentes nas últimas décadas. Para tanto, num primeiro momento, esta pesquisa demonstra como as doenças infecciosas têm sido entendidas pela literatura especializada como parte das novas dimensões de segurança internacional. O primeiro capítulo apresenta os resultados dessa investigação e sistematiza cinco abordagens diferentes da compreensão de doenças infecciosas como um tema de segurança internacional.

O segundo capítulo discute as formas adequadas de analisar a governança na agenda de saúde global - em que se insere o tema das DIEs. Para tanto, aborda diversas teorias sobre governança e suas implicações analíticas, propondo uma diferenciação entre governança global e internacional. Em seguida, mapeiam-se as condições governança das doenças infecciosas, visando distingui-la da governança que se preocupa especificamente com as DIEs.

O terceiro capítulo analisa o principal dispositivo normativo internacional sobre doenças infecciosas para compreender como se desenvolveu a governança internacional das DIEs nas últimas décadas. Para tanto, será analisado o surgimento e funcionamento do regime internacional de alerta, controle, prevenção e resposta a esses riscos.

Essa pesquisa destaca a relação entre saúde global e relações internacionais. Isso significa que o estudo pretende chamar a atenção para o temário da saúde global no âmbito da política internacional, dedicando especial atenção à atuação da Organização Mundial da

\footnotetext{
${ }^{5}$ Nesse sentido, a adoção da expressão "novas dimensões de segurança internacional" é dirigida muito mais à comunidade acadêmica de relações internacionais do que a dos sanitaristas, pois só recentemente aqueles tem abordado temas não militares como variáveis importantes nos estudos de segurança.

${ }^{6}$ A definição de doenças infecciosas emergentes, fundamental para o recorte dessa pesquisa, é objeto de discussão aprofundada no segundo capítulo.
} 
Saúde (OMS) - que historicamente domina a agenda da saúde (DAVIES, 2008). Nesse sentido, é vital a aproximação dos programas de estudo de relações internacionais e da saúde, que, por vezes, estão concentrados isoladamente nos profissionais das diferentes áreas. Logo, há a necessidade de inclusão definitiva e do tratamento de temas afetos a saúde global, diplomacia em saúde e governança da saúde global nas agendas de pesquisa de relações internacionais. Presume-se que a verdadeira aproximação desses dois campos - em termos teóricos, conceituais e analíticos - possa contribuir para o aprimoramento da produção de conhecimento em ambos os lados.

Abordar nessa pesquisa os nexos entre saúde global e segurança internacional responde ao fato de que a comunidade internacional confere crescente ênfase a essa relação. Em pelo menos duas dimensões formais isso pode ser verificado. Primeiro, a resolução aprovada pela Assembleia Mundial de Saúde, o principal órgão deliberativo da Organização Mundial da Saúde, em 2001, intitulada "Global health security: epidemic alert and response". Nesse documento, aludindo ao intenso processo de globalização do comércio e tráfego de pessoas e ao combate às doenças infecciosas como uma prioridade da saúde pública, a Assembleia afirma que qualquer epidemia de doenças infecciosas em um determinado país é motivo de preocupação para a comunidade internacional.

Segundo, na Resolução 1983 (2011) sobre a epidemia de HIV/AIDS, o Conselho de Segurança da ONU reconhece que "o HIV coloca um dos desafios mais formidáveis para o desenvolvimento, progresso e estabilidade das sociedades e requer resposta global de sistemática e excepcional” (UNITES NATIONS SECURITY COUNCIL, 2011, p.1). A adoção dessa resolução pelo órgão configura não só um fato significativo no que tange à relação entre saúde e segurança internacional e evidencia, com ênfase, as novas dimensões de segurança internacional.

Existe, ainda, a dimensão ética no estudo das políticas que compreendem a saúde global. Analisar como se desenvolve a governança das doenças infecciosas é o primeiro passo para avaliar as repercussões e impactos dessas políticas em termos bioéticos. No recorte proposto por esta pesquisa, essa noção se torna ainda mais evidente, ao confrontar a saúde com dimensões afetas à segurança internacional e à elaboração e implementação de determinadas políticas públicas - internacionais e domésticas - para seu controle.

Há outras justificativas para esta investigação. Sérias preocupações a respeito do impacto das DIEs no mundo advogam em favor do desenvolvimento dessa pesquisa. A pandemia da gripe espanhola, em 1918, causou a morte de aproximadamente 50 milhões de pessoas (TAUBENBERGER; MORENS, 2006). No caso da recente pandemia de 2009, 
causada pelo vírus Influenza A (H1N1), especialistas estimaram que, apesar do baixo índice de propagação global da doença, houve 201.200 mortes diretamente associadas com esse agente causador (DAWOOD et al., 2012). Todos os anos, novas cepas de vírus da gripe sazonal surgem e se proliferam pelas populações. A natureza evolutiva imprevisível dos agentes patogênicos - em especial dos vírus - coloca profissionais de saúde pública, tomadores de decisão e outros agentes envolvidos no controle dessas doenças em face de um desafio constante.

Em suma, o argumento aqui desenvolvido demonstra que as doenças infecciosas têm sido entendidas pela literatura especializada como parte das novas dimensões de segurança internacional. Essa compreensão produz implicações que interferem ao mesmo tempo no campo das Relações Internacionais e no da saúde global: o desenvolvimento do regime e, consequentemente, da governança internacional dessa matéria. 


\section{DOENÇAS INFECCIOSAS À LUZ DAS NARRATIVAS SOBRE SEGURANÇA INTERNACIONAL}

O objetivo desse capítulo é organizar e analisar a literatura especializada que discute o entendimento das doenças infecciosas como um tema de segurança. Demonstra-se que as doenças infecciosas são parte das chamadas novas dimensões da segurança internacional ${ }^{7}$ e examinam-se possíveis vertentes dessa aproximação.

Para tanto, a partir do exame das contribuições de autores sobre o assunto, foi possível apresentar uma forma de organizar essa discussão, propondo uma classificação preliminar de cinco abordagens para a relação entre doenças infecciosas e segurança internacional: (1) tradicional; (2) securitizadora; (3) "health security"; (4) segurança humana; e, (5) críticoconstrutivista. Ao identificar e descrever os principais componentes analíticos dessas vertentes (ontologia, referentes de segurança e metodologias empregadas), e considerando-se a discussão de certos temas abordados pelos autores, espera-se que seja possível apresentar ao leitor o debate acadêmico sobre esse tema.

Cada uma dessas abordagens desenvolve visão peculiar da relação entre doenças infecciosas e segurança internacional. A sistematização de cada uma delas só foi possível após abrangente análise dessa literatura, que levou em consideração artigos (publicados em periódicos das áreas de saúde pública e relações internacionais ou de outros campos interdisciplinares), capítulos e livros que discutem essa matéria. Por isso, as abordagens não são necessariamente perspectivas teóricas, correntes ou escolas de pensamento consolidado. Logo, não há a vinculação de caráter exclusivo entre um determinado autor e uma dada abordagem: um mesmo autor que analisa a relação entre doenças infecciosas e segurança pode destacar aspectos diferentes dessa dinâmica de maneira coerente, contribuindo, assim, para análises diferentes do problema.

Dessa forma, cada abordagem deve ser entendida como uma coleção de noções consistentes e coerentes entre si, que favoreçam entender as doenças infecciosas como tema de segurança internacional, a partir das contribuições de autores que analisam fenômenos diversos dessa agenda.

Dentre as abordagens propostas, foi possível verificar, no decorrer da pesquisa, que a tradicional é a principal e mais recorrente na literatura especializada - o que explica a

\footnotetext{
${ }^{7}$ Essa expressão refere-se à revisão do conceito de segurança internacional na literatura contemporânea de Relações Internacionais que procura, em linhas gerais, alargar sua definição a fim de incluir novas referentes de segurança internacional além dos que foram considerados pelas abordagens neorrealistas e suas variantes. Isso será discutido em mais detalhe ao longo desse capítulo.
} 
extensão dedicada a sua discussão nesse capítulo. Por isso, entende-se que essa seja uma vertente fundamental para o estudo do fenômeno. Para caracterizá-la em profundidade, optouse por analisar com maior atenção dois casos pertinentes: (1) campanhas de vacinação como instrumentos de promoção da segurança; e, (2) guerra biológica e bioterrorismo.

Conforme é defendido nesse capítulo, a abordagem tradicional mostrou-se insuficiente para compreender todas as variáveis da relação entre doenças infecciosas e segurança. Isso abriu espaço para o surgimento das quatro outras vertentes citadas acima e agrupadas aqui na sessão "abordagens revisoras", considerando que todas dialogam diretamente com o arcabouço teórico e conceitual fundado pela abordagem tradicional. A discussão evidenciará a insuficiência da abordagem tradicional, ao mesmo tempo em que apontará para a crescente complexidade do binômio doenças infecciosas-segurança internacional.

\subsection{Abordagem tradicional}

$\mathrm{Na}$ abordagem tradicional da relação entre doenças infecciosas e segurança internacional estão destacados os temas que dizem respeito aos assuntos militares, à segurança nacional e à defesa. Mais do que apenas priorizar temas dessa natureza, essa noção tradicional afirma que as doenças infecciosas importam na medida em que impactam a segurança do Estado.

Por isso, entende-se que essa abordagem é em parte orientada pela noção clássica de segurança internacional, encontrada na literatura acadêmica de Relações Internacionais. Esse conceito ganha aplicação acadêmica de maneira consistente nas teorias de cunho realista que a define como ameaça externa à integridade e/ou à sobrevivência do Estado (WALTZ, 1979). Os fatores que constituem ameaças para o neorrealismo são primordialmente de cunho militar, devido à sua abordagem racional e materialista, e respondem à estrutura do sistema internacional, ordenado segundo as condições de equilíbrio de poder. Segundo a tipologia trazida por David Fidler (2002) em artigo sobre saúde pública e segurança, essa abordagem se enquadra no paradigma da realpolitik. Nesse sentido, segundo argumentam Nuzzo e Gronvall (2011), o engajamento de um Estado em assuntos da saúde global - em especial relativo às doenças infecciosas - é percebido como forma de fortalecer a sua própria segurança nacional.

Nesse sentido, a abordagem tradicional é informada pelo referente de segurança adotado na noção clássica de segurança internacional: o Estado. No entanto, a abordagem tradicional, conforme caracterizada nessa pesquisa, não se limita a compreender apenas as ameaças externas ao Estado, como faz a concepção clássica do termo. As doenças infecciosas 
também são assuntos de interesse para essa agenda, pois afetam a segurança nacional, inclusive por dentro e de dentro dos Estados - ao atingirem, por exemplo, os contingentes militares ${ }^{8}$. O que a difere das demais abordagens apresentadas neste capítulo é o fato de que a abordagem tradicional faz prevalecer a dimensão militar e de segurança nacional na relação entre segurança e doenças infecciosas. Nela, as doenças infecciosas são um assunto que se inscreve no campo da defesa.

O termo "tradicional" foi escolhido para nomear essa abordagem em alusão, em primeiro lugar, às conceituações clássicas de segurança internacional. Convenientemente, a tradicionalidade dessa noção também se refere à história da saúde internacional que descreve como as doenças infecciosas receberam especial atenção, no âmbito tanto da saúde pública quanto da diplomacia, no tocante à segurança sanitária internacional desde o século XIX (AGINAM, 2004; FIDLER, 1998, 2005; PEREIRA, 2008).

Além disso, optou-se por denominar essa abordagem "tradicional" por se reconhecer que as outras propostas nesse capítulo fundam sua compreensão em torno da primeira - no sentido de complementá-la, revisá-la ou criticá-la. Em comum entre todas as outras contribuições que procuram dialogar com a abordagem tradicional, está o reconhecimento da necessidade de alargamento dessa agenda para a inclusão de outros atores, variáveis e temas (MCINNES; LEE, 2006), como, por exemplo: a relação entre saúde, instabilidade doméstica e segurança internacional; a importância de considerar a segurança do indivíduo nessa dinâmica; e, a relevância das narrativas e interpretações dos atores imersos no processo.

Os temas tratados no âmbito da abordagem tradicional coincidem com os que Jonathan Ban (2003, p.21) chamou de "ameaças diretas à segurança". Para o autor, algumas das ameaças à saúde pública estão diretamente relacionadas às considerações tradicionais de segurança internacional, como, por exemplo, bioterrorismo, ataques às instituições de saúde, impacto das doenças infecciosas sobre contingentes militares, entre outros. De maneira complementar, Colin McInnes e Kelley Lee (2006) destacam que a agenda de pesquisa que procura entender as relações entre política externa e segurança, de um lado, e saúde pública global, de outro, tem sido dominada por dois temas: a disseminação de doenças infecciosas e bioterrorismo. Os autores defendem que essa agenda tem priorizado os interesses das perspectivas de segurança internacional sobre as de saúde, o que corrobora a proposta de uma abordagem tradicional do tema.

\footnotetext{
${ }^{8}$ A rigor, a abordagem tradicional discutida aqui não se limita ao nível de análise sistêmico adotado pela teoria neorrealista. Nesse sentido, quanto aos níveis de análise, essa abordagem aproxima-se da vertente realista (e não neorrealistas) das relações internacionais cujo referente de segurança é o Estado, sem privilegiar explicações de cunho sistêmico.
} 
Entretanto, Peterson (2002) foi quem realizou a mais consistente sistematização da abordagem tradicional da relação entre doenças infecciosas e segurança internacional. Ao investigar os mecanismos causais existentes entre a ocorrência das doenças infecciosas e a segurança nacional, a autora afirma que aqueles que propõem o alargamento do conceito de segurança nacional e internacional - como é o caso dos que aderem à abordagem de "human security" - não conseguiram analisar sistematicamente a relação identificada entre doenças infecciosas e segurança internacional. Tampouco essas novas definições de segurança se integraram aos debates centrais da literatura, pois não encontram ressonância nos entendimentos tradicionais de segurança nacional e internacional, cuja ontologia se encontra necessariamente nas ameaças físicas ao Estado.

Com essas considerações em mente, Peterson (2002) argumenta que há duas formas distintas em que as doenças infecciosas podem afetar a segurança nacional: causando a eclosão de conflitos militares ou alterando o resultado de um conflito em andamento.

Três mecanismos causais hipotéticos são listados pela autora para caracterizar a relação entre a ocorrência de doenças infecciosas e a eclosão de conflitos militares: (1) a alteração no equilíbrio de poder; (2) o surgimento de contenciosos nas políticas externas dos países e (3) os impactos sociais das epidemias. Segundo a autora, dessas três hipóteses, atualmente, apenas a última apresenta uma provável ameaça à segurança nacional (PETERSON, 2002, p.64). Se é verdade que a segurança nacional depende da estabilidade interna, os impactos sociais, econômicos e políticos das epidemias podem levar à instabilidade doméstica, à guerra civil, à confrontos entre civis e militares e até mesmo a conflitos internacionais. Essa formulação é semelhante à proposta da abordagem de "health security", que será discutida com maior atenção na sessão seguinte. Dessa forma, os parágrafos que se seguem são dedicados à análise e à discussão dos dois primeiros mecanismos causais.

No primeiro caso, o início de um conflito internacional pode se dar devido ao impacto das doenças infecciosas no equilíbrio de poder entre países. As doenças infecciosas, ao afetarem contingentes militares e a população, levariam à erosão e ao enfraquecimento dos setores militares responsáveis pela Defesa nacional. O Estado, ao se dar conta disso, calcula perdas e ganhos relativos a outras nações - um raciocínio alinhado à perspectiva neorrealista nas Relações Internacionais. Esse cálculo capacita o Estado a medir seu poder relativo e avaliar se houve alteração no equilíbrio de poder. O aumento da insegurança a respeito do poder relativo de cada um desses atores aumenta as chances de conflito. 
Alterações no equilíbrio de poder militar também podem se dar quando uma das partes em conflito é acometida por uma doença infecciosa à qual a outra parte é imune. Exemplos dessa dinâmica são encontrados nas guerras de conquista, como foi o caso das doenças trazidas pelos Europeus dizimaram cerca de $95 \%$ da população nativa no território norteamericano, a partir de 1492 (DIAMOND, 1999). No entanto, Peterson reconhece que há pouca evidência de que as alterações no equilíbrio de poder causados pelas doenças infecciosas seja uma variável importante na eclosão e desenvolvimento dos conflitos militares. Ademais, em contraste com períodos históricos nos quais se deram os casos das guerras de conquistas, no mundo contemporâneo a relação entre doenças infecciosas e o equilíbrio de poder entre as nações é muito mais complexa. Atualmente, para além do tamanho dos contingentes militares e das capacidades imunológicas, diversos outros fatores interveem nessa relação, como, por exemplo, avanços tecnológicos no setor bélico.

A segunda hipótese acerca da relação entre doenças infecciosas e a eclosão de guerras é a de que a ocorrência de epidemias pode levar a conflitos militares quando fazem surgir contenciosos entre os Estados acometidos por essas epidemias. Exemplos desses contenciosos são a instituição de quarentenas e embargos; e as disputas em matéria de propriedade intelectual de patentes de medicamentos. Contudo, ao lidar com o combate às epidemias, os Estados muitas vezes são forçados a redistribuir seus recursos no orçamento, preferindo investir em programas domésticos a lidar com os custos de engajamento diplomático em negociações internacionais, de disputas comerciais ou até mesmo da guerra. Por esse motivo, conforme a própria autora afirma, é improvável que qualquer desses dois contenciosos seja fator causador de conflito militar entre Estados. Por outro lado, Peterson argumenta que epidemias podem facilitar a cooperação internacional.

As doenças infecciosas também podem afetar os resultados de conflitos militares. Essa relação manifesta-se pelo menos de duas maneiras: nos ataques diretos à saúde pública e no impacto sobre a prontidão e disponibilidade dos contingentes militares.

Para compreender a relação entre os ataques à saúde pública e doenças infecciosas no contexto de conflitos, Peterson (2002) se apropria da tipologia de guerra humanitária de Chow (1996). Segundo esse autor, uma das formas de guerra humanitária ocorre ao se infligir a fome sobre a população ${ }^{9}$. Nesse caso, segundo Peterson (2002), ocorre a proliferação das doenças infecciosas devido à subnutrição. Outra forma de guerra humanitária é por meio da

\footnotetext{
9 “war by starvation”, no original em inglês.
} 
privação $^{10}$ e diz respeito aos ataques cujo objetivo é eliminar o provimento de alimentos, água, medicamentos e/ou aquecimento (CHOW, 1996).

Nesse caso, a relação entre o conflito e as doenças infecciosas se dá por meio da deterioração das condições, serviços e estruturas normais de saúde pública, entendida como um conceito abrangente que engloba, entre outros aspectos, alimentação apropriada, moradia e saneamento básico até à disponibilidade de vacinas, drogas e tratamentos médicos de alta complexidade. Por isso, conclui-se que ataques a esses serviços contribuam com o surgimento de novas e o agravamento das epidemias já existentes em uma população.

O impacto das doenças infecciosas sobre os militares também pode afetar o desenvolvimento de conflitos. Segundo Ban (2003), epidemias de ocorrência natural são as principais causas de mortes entre contingentes militares em contexto de conflito. Na Guerra Civil norte-americana, cita o autor, estima-se que um número maior que o dobro dos combatentes mortos no front tenha morrido em decorrência de infecções. As guerras de conquista no século XVI também evidenciam o mesmo. A população asteca foi praticamente dizimada pela varíola trazida pelos exploradores espanhóis liderados por Hernán Cortez, a partir de 1520. Em 1532, o exército inca de 80.000 homens foi derrotado por Francisco Pizarro acompanhado de um contingente de apenas 168 homens após uma epidemia também de varíola que erodiu a ordem na sociedade nativa instaurando a guerra civil ${ }^{11}$.

Segundo Ban (2003), apesar de as doenças infecciosas afetarem a prontidão dos contingentes militares e a efetividade de suas operações, ainda assim os atores nos círculos militares raramente conferem atenção suficiente a esses riscos (BAN, 2003). Peterson, apesar de reconhecer a importância histórica das epidemias na definição de conflitos, afirma que, no sistema internacional contemporâneo, essa relação se dá de maneira diferente. Sua análise se limita a interpretar o impacto da AIDS que, diferentemente dos casos citados acima, teria impactos sobre as forças militares no longo prazo. De acordo com esse raciocínio, uma epidemia da doença na população em geral levaria à diminuição dos contingentes militares. De fato, atualmente, em diversos países da África subsaariana onde grande parcela da população é portadora do vírus o recrutamento e a manutenção de um exército saudável e ativo é um desafio.

\footnotetext{
10 "war by privation", no original em inglês.

${ }^{11} \mathrm{O}$ papel das doenças infecciosas como variáveis determinantes no curso da história, devido ao seu papel de dizimar populações e exércitos, são analisados em duas obras: "Germs, Guns and Steel: the fates of human societies", de Jared Diamond (1997) e "Plagues and Peoples", de William H. McNeill (1976).
} 


\subsubsection{Problematizando casos pertinentes à abordagem tradicional}

a) Campanhas de vacinação como instrumentos de promoção da segurança

Hotez (2001) argumenta que empreitadas políticas de desenvolvimento de vacinas e a consequente imunização das populações em risco em escala internacional teriam o potencial de resolução de $\operatorname{conflitos}^{12}$. Para defender essa ideia, o autor cunha a expressão "vaccine diplomacy", que em alusão à "subestimada função das vacinas em promoverem a paz" (HOTEZ, 2012, p.1301).

Um dos casos discutidos pelo autor remonta à época da Guerra Fria em que o agravamento da epidemia de poliomielite em ambos os blocos levou norte-americanos e soviéticos a cooperarem num programa de desenvolvimento de uma nova vacina, a despeito da competição entre as duas superpotências no período. Essa vacina seria posteriormente testada em milhões de crianças da União Soviética antes de ser aprovada para inoculação nos EUA. Questionamentos de cunho bioético a parte, esse caso demonstra senão a capacidade da política de vacinação propiciar a instauração da paz, pelo menos a viabilidade da cooperação que se sobressaiu ao momento de conflito internacional (HOTEZ, 2010, 2012a, 2012b).

Independente da validade desse argumento, alguns episódios relacionados às campanhas de prevenção à poliomielite e a política internacional merecem ser considerados. Em 1988, a Assembleia Mundial da Saúde adotou uma resolução em prol da erradicação global da poliomielite, na esteira do bem-sucedido programa que erradicou a varíola, concluído em 1980. Essa resolução também marcou o início do Global Polio Erradication Initiative $^{13}$, um esforço internacional envolvendo a OMS, UNICEF, CDC e diversos outros atores. Desde então, a incidência da poliomielite em todo o mundo caiu em 99\%: uma redução de 350.000 casos distribuídos em 125 países onde a doença era endêmica, para 223 casos em 2012. Em 2013, apenas três países ainda permanecem como regiões endêmicas da doença: Nigéria, Afeganistão e Paquistão ${ }^{14}$ (WHO, 2013a).

\footnotetext{
${ }^{12}$ Hotez cita as vacinações em massa organizadas, no Dia Nacional da Imunização, pelas agências da ONU, no Afeganistão desde 1994, chamados de "days of tranquility"; o cessar-fogo negociado pelo presidente norteamericano Jimmy Carter, em 1995, durante o conflito civil no Sudão, para ajudar a reduzir a incidência da doença parasitária dracunculíase; entre outros.

${ }^{13}$ Mais informações sobre a iniciativa podem ser acessadas em: http://www.polioeradication.org/

${ }^{14}$ Há um Plano de Ação Emergencial para a Erradicação Global da Poliomielite que foi desenvolvido com o intuito de incrementar e aprimorar a cobertura imunológica contra a doença nesses três países WORLD HEALTH ORGANIZATION, 2012a).
} 
Segundo Hotez (2001), até hoje campanhas de vacinação contra essas doenças conduzidas pela OMS, UNICEF e outras agências da ONU em diversas regiões da África e da Ásia impulsionam negociações de cessar-fogo. Em 2000, o governo afegão entrou em acordo com a UNICEF em prol do cessar-fogo por três dias a fim de viabilizar o programa de imunização, dando continuidade à instituição do Dia Nacional da Imunização, realizado no país desde 1994 (UNICEF, 2000).

Em outubro de 2013, o Conselho de Segurança, em nota à imprensa, expressou grave preocupação com a epidemia de poliomielite no Sudão, onde o conflito civil em curso impediu o desenvolvimento da campanha de vacinação. O Conselho rogou ao governo sudanês e ao Movimento de Libertação do Povo do Sudão que resolvessem disputas a fim de acertar um plano técnico que garantisse a realização da campanha, preocupado com o aumento de casos da doença no Chifre Africano. A campanha havia sido proposta em conjunto pelo Escritório das Nações Unidas para a Coordenação de Assuntos Humanitários, UNICEF e OMS e para as áreas de Kordofan do Sul e do Nilo Azul, regiões em que cerca de 165.000 crianças estariam em risco de contrair a doença (UNITED NATIONS NEWS CENTER, 2013). Episódios de trégua em conflitos devido à realização de programas de vacinação contra a poliomielite - bem como de outras doenças - também foram registrados no Timor-Leste, El Salvador, Burundi e Paquistão, entre outros países ${ }^{15}$.

À primeira vista, esses casos apontam para capacidade de campanhas de vacinação estimular cessar-fogo e tréguas em conflitos, o que corrobora o argumento da "vaccine diplomacy". Contudo, essa relação tem se problematizado substancialmente. Orin Levine, diretor executivo do International Vaccine Access Center, e Laurie Garrett, especialista em saúde global, em artigo de opinião para o The Washington Post, argumentam que profissionais de saúde pública enviados ao Paquistão e Afeganistão para participar de campanhas de vacinação são vistos pelas populações locais como espiões. O diretor também explica que a rejeição da vacina pode estar associada a um "medo de natureza política"16. (LEVINE; GARRETT, 2011). Essa resistência tem se traduzido, em algumas regiões, em

\footnotetext{
${ }^{15}$ Para mais informações sobre o impacto de campanhas de vaccinação em conflitos domésticos, consultar: REUTERS. UN Urges Uganda Truce for Measles Immunization. 2003. Disponível em: <http://www.immunizationinfo.org/pressroom/news-briefs/2003-10-09/un-urges-uganda-truce-measlesimmunization>. Acesso em: 23 out. 2014.; UNICEF. East Timor truce allows immunization. 1999. Disponível em: <http://www.unicef.org/newsline/99pr25.htm>. Acesso em: 23 out. 2014.; THE NEW YORK TIMES. Immunization Truce Interrupts Salvador War. 1987. Disponível em: <http://www.nytimes.com/1987/02/26/opinion/l-immunization-truce-interrupts-salvador-war-674287.html >.

Acesso em: 23 out. 2014. THE NEW YORK TIMES. Afghan Truce to Allow Polio Vaccinations. 2000. Disponível em: <http://www.nytimes.com/2000/04/22/world/afghan-truce-to-allow-polio-vaccinations.html>. Acesso em: 23 out. 2014.

16 "politically derived fear", no original em inglês.
} 
ataques contra as equipes internacionais de vacinação, em especial na Nigéria, Afeganistão e Paquistão (BUNCOMBE, 2014; MCNEIL, 2013).

Além disso, os programas de vacinação em diversas regiões tem sido comprometidos devido a uma série de rumores em determinadas comunidades. Na Nigéria, famílias temem administrar vacina contra poliomielite por acreditarem que ela seria parte de um plano de conspiração do Ocidente para esterilização feminina (ASSOCIATED PRESS, 2006). No Quênia, havia medo de que essa mesma vacina causasse a perda da língua. No Paquistão, líderes muçulmanos pregaram contra a vacinação argumentando que essa seria contra a lei islâmica e que causaria infertilidade aos que a recebessem (SPENCER, 2007). Esses rumores todos dificultam a atuação das equipes de saúde pública in loco, ou até mesmo impedem a formulação desses programas.

Em 2011, a CIA organizou uma campanha de vacinação falsa contra a hepatite B em Abbottabad, no norte do Paquistão, cidade em que se acreditava que Osama Bin Laden estaria escondido. A operação foi parte de um intrincado plano para obter amostras do DNA de familiares do terrorista e contou com a colaboração de um experiente médico da região, que foi encarregado de organizar a campanha de vacinação na cidade onde a CIA havia rastreado o possível paradeiro de Bin Laden, seguindo o trajeto de um mensageiro da al-Qaeda. Assim, o projeto de imunização falsa possibilitou confirmar a localização de Bin Laden e foi seguido da operação do esquadrão de elite que eliminou o terrorista. O caso foi exposto em primeira mão pelo jornal britânico The Guardian, em julho de 2011 e causou enorme repercussão na mídia internacional, nos círculos diplomáticos e na comunidade de saúde global (SHAH, 2011).

O envolvimento da CIA na armação da falsa campanha de vacinação recebeu severas e preocupadas críticas de diversas frentes. Utilizar-se de uma motivação humanitária para obter informações de interesse nacional norte-americano contribuiu para o aumento da desconfiança por parte de certos grupos, em especial extremistas islâmicos e grupos políticos radicais de orientação anti-Ocidente, quanto às instituições internacionais - organizações nãogovernamentais, organismos internacionais e outros atores - que atuam nessa esfera. Além disso, a ação elevou risco para os profissionais cooperantes em campanhas de vacinação bem como de outros projetos de ajuda humanitária e também serviu como combustível para teorias da conspiração acerca dos interesses Ocidentais e do engajamento da política externa dos EUA em saúde global (IGNATIUS, 2012; MCNEIL, 2013b, 2014; WALSH, 2012).

Esse escândalo da falsa campanha de vacinação arranjada pela CIA no Paquistão realça a instrumentalidade das campanhas de vacinação para atingir interesses de política 
externa - no caso em questão, dos EUA - em matéria de segurança. Isso coloca o argumento da "vaccine diplomacy" em cheque uma vez que essas ações de pesquisa, desenvolvimento e implementação de imunização em massa em escala internacional podem compor um intrincado tabuleiro em que se cruzam questões como assistência humanitária, cooperação, persecução de interesses nacionais, desconfiança civil, instabilidade doméstica e segurança nacional.

Dessa forma, os casos discutidos acima levantam dúvidas quanto à associação direta entre vacinação e promoção da paz que a formulação da "vaccine diplomacy" propõe. Ainda assim, fica claro que a relação entre doenças infecciosas e segurança internacional é mais complexa do que nos informa o framework da abordagem tradicional, pois há também a necessidade de envolver as percepções e expectativas dos diversos atores como variáveis relevantes. Por isso, ressalta-se a importância de considerar a construção social de significados nessa relação. Essa dimensão será discutida com maior propriedade adiante na sessão que trata da abordagem crítico-construtivista.

b) Guerra biológica e bioterrorismo

Guerra biológica, descrita por Rosebury (1949) como "saúde pública ao contrário", é, por definição, o caso onde a relação entre doenças infecciosas e segurança é mais facilmente percebida. É também o caso em que está destacado o nexo entre doenças infecciosas e assuntos de natureza militar no contexto de segurança e defesa, característico da abordagem tradicional proposta nesse capítulo.

Armas biológicas são microrganismos patogênicos (bactérias, vírus, fungos, príons, protozoários e rickettsias) ou substâncias oriundas de secreções de organismos ou produzidas artificialmente para mimetizá-las (toxinas) que são deliberadamente disseminados para causar doenças e morte em seres humanos, plantas ou animais (ENEMARK, 2007). Geralmente, são mecanismos compostos de duas partes: o agente causador e um mecanismos de liberação. Há uma grande variedade de agentes causadores de doenças que podem ser transformados em armas biológicas, sendo que, historicamente, os principais seriam antraz, aflatoxina, toxina botulínica, febre aftosa, peste, febre Q, ricina, varíola, tularemia, entre outros. (ENEMARK, 2007; PETERSON, 2002; UNITED NATIONS OFFICE AT GENEVA, 2014).

O uso de organismos biológicos como armas difere de sua propagação epidêmica de ocorrência natural. De fato, vale ressaltar que agentes patológicos por si só não são equivalentes a armas biológicas. Para que um agente causador de uma doença possa ser 
utilizado com o intuito de promover sua propagação de maneira proposital, ele precisa ser transformado em arma ${ }^{17}$. Isso significa que o agente causador deve ser dotado do potencial de contaminar o alvo e também de um mecanismo de distribuição ${ }^{18}$.

Diferentemente das epidemias de ocorrência natural, a utilização de armas biológicas é o exemplo em que a articulação entre doenças infecciosas e segurança é mais bem percebida e, por isso, é o principal candidato a ganhar atenção da comunidade política (PETERSON, 2002). Outras características do fenômeno das armas biológicas também contribuem para que elas recebam atenção especial nessa matéria: elas representam ameaças diretas aos EUA e a outros países ocidentais; são de fácil produção e armazenamento; e, por não serem tecnologias bélicas novas, prescindem de capacidades técnicas, estruturas ou equipamentos sofisticados para serem produzidas. Por todos esses motivos, as armas biológicas encaixam-se melhor nas definições tradicionais de segurança internacional do que as doenças infecciosas se consideradas isoladamente (PETERSON, 2002, p.70).

Quando comparadas a outras ameaças bélicas, o uso de armas biológicas apresenta dinâmica peculiar, que merece consideração pela defesa nacional de um país. Se o uso de outras armas de destruição em massa - nucleares ou químicas, por exemplo - traz resultados imediatos, as armas biológicas podem ter impactos imprevisíveis nas populações devido às características de propagação do agente causador e seus consequentes desdobramentos epidemiológicos. Por isso, programas e ações preventivas nos âmbitos local, nacional e internacional podem fazer a diferença ao se lidar com os resultados do uso de equipamentos bélicos desse gênero. Além disso, as armas biológicas são opções atrativas para qualquer Estado ou grupo político que deseje infligir prejuízo a algum inimigo e não ser detectado (HOYT; BROOKS, 2003).

Em contraste com outros recursos, o componente biológico desse tipo de arma torna difícil a identificação precisa do local (devido à mobilidade de pessoas e bens que carregam consigo o agente infeccioso) e do momento (devido à variabilidade do período de incubação e de propagação do agente) de sua detonação.

Como dito, diversos agentes infecciosos podem ser intencionalmente liberados na população. Além dos riscos colocados pelo antraz, na eventual ocorrência de um ataque de armas biológicas, muita atenção tem sido dada especificamente à possibilidade de uso do vírus da varíola como agente infeccioso (BERCHE, 2001; ATLAS, 1998; LIGON, 2001). Após a doença ser erradicada por meio de um extenso programa liderado pela OMS, de 1966

\footnotetext{
${ }^{17} \mathrm{Na}$ ausência de tradução justa para o termo da língua inglesa "weaponization", optou-se por essa expressão.

18 “delivery mechanism", no original em inglês.
} 
a 1977 (JEZEK, 1987), essa mesma organização preocupou-se em limitar a disponibilidade laboratorial das amostras do vírus, presente, em 1975, em pelo menos 75 laboratórios. Após acidente que resultou em dois casos de varíola no laboratório da Universidade de Birmingham, em 1978 (BIRMINGHAM MAIL, 2011; BAKHSHI, 2003), a Organização adotou resolução rogando pela destruição de todas as amostras e nomeando, em 1984, dois laboratórios estatais para possuir os últimos exemplares do vírus (LIGON, 2001): US Centre for Disease Control and Prevention (CDC), em Atlanta, nos EUA; e o State Research Institute for Viral Preparations (Vector), em Moscou, Rússia. A escolha dessas localizações foi feita pelo fato de que as duas instituições foram referência na campanha global de erradicação da doença e por possuírem as maiores coleções do vírus (TUCKER, 2012).

Mais de vinte anos após a erradicação da doença, um acalorado debate toma conta da Assembleia Mundial da Saúde, a reunião anual dos membros da OMS, acerca da destruição das cepas da varíola. Em 1996, os EUA apoiaram uma resolução que orientava a destruição de todas as amostras restantes do vírus estocadas no CDC e Vector. No entanto, nos anos que se seguiram, cresceu a preocupação, por parte do Departamento de Defesa dos EUA, com a possibilidade de posse ilegal do vírus por países visando ao desenvolvimento de armas biológicas para uso militar e terrorista. Indícios coletados pela Central Intelligence Agency (CIA) afirmavam que países como Irã, Coreia do Norte e Iraque possuiriam ilegalmente o vírus (ATLAS, 1998).

Além disso, preocupavam também as declarações do alto oficial russo Kanatjan Alibekov, quando radicado nos EUA, sobre a existência de um longo programa da União Soviética para a produção de armas biológicas de destruição em massa (PBS, 2014; ATLAS, 1998). Esses fatores, juntamente com os atentados de 11 de setembro e os episódios do anthrax, e a diminuição da parcela da população norte-americana imune à doença (HENDERSON, 1998; 2011), levaram a uma mudança da postura dos EUA em relação à destruição dos estoques da varíola, dando início, na década que se seguiu, a um intenso esforço diplomático pela prorrogação indefinida da destruição das amostras.

Peterson (2012) argumenta que o advento das armas biológicas coloca dois desafios para a segurança internacional. Em primeiro lugar, o investimento feito por um Estado em programas de desenvolvimento de armas biológicas pode despertar a preocupação da comunidade internacional - ou particularmente de outros Estados, o que, por sua vez, pode desencadear guerras de caráter preventivo (REITER, 2006). Em segundo lugar, o acesso à tecnologia que a construção de um artefato do gênero requer é muito mais simples e de mais 
fácil acesso se comparada à necessária para o desenvolvimento de um mecanismo nuclear (SIMPSON, 2014) o que favorece seu uso por grupos não-Estatais ou terroristas.

Por isso, diferentemente da guerra biológica interestatal, sujeita aos regimes de proibição da guerra biológica, grupos terroristas com diversas motivações políticas podem se valer de ogivas biológicas e utilizá-las de maneira distinta do que corpos militares que executam estratégias e orientações elaboradas pelos setores de defesa nacional o fazem. Nesse sentido, a análise do bioterrorismo deve procurar compreendê-lo como um fenômeno à parte do terrorismo "tradicional" e do uso de armas biológicas por forças estatais (ACKERMAN, MORAN, 2006).

O documento "Bioterrorism and threat assessment", publicado pela The Weapons of Mass Destruction Commission em 2006, cita diversas recomendações à comunidade internacional para combater a ameaça ao bioterrorismo atualmente. Entre essas, está a de identificar a saúde pública - entendendo essa enquanto setor de atuação do Estado - como um componente chave da segurança internacional.

Segundo os autores, é fundamental reconhecer que vários países não têm capacidades de combater a disseminação de doenças infecciosas, o que resulta na sobrecarga dos serviços de saúde, compromete o desenvolvimento das sociedades e desestabiliza as comunidades. Devido ao fato de que as mesmas condições de combate e controle de epidemias de ocorrência natural também serem formas de segurança contra os impactos do bioterrorismo (ENEMARK, 2007; 2010; WORLD HEALTH ORGANIZATION, 2003d), é necessário abordar a saúde pública como uma preocupação comum em matéria de segurança. Para tanto, recomenda-se a adoção de estratégias cooperativas para o aprimoramento das capacidades profiláticas e de resposta, especialmente as de vigilância sanitária e compartilhamento de informações (ACKERMAN, MORAN, 2006, p.17).

Como mencionado, as mesmas medidas adotadas na esfera da saúde pública para combater doenças infecciosas também servem para minimizar os efeitos de ataques de armas biológicas. Nesse âmbito, a imunização da população é um exemplo de ação que impacta tanto a defesa quanto a saúde pública. Segundo o que discutem Hoyt e Brooks (2004), as vacinas, ao limitarem a eficácia das armas biológicas, funcionam como mecanismos de dissuasão (MCINNES; LEE, 2006). Por isso, políticas de incentivo ao desenvolvimento de vacinas devem ser encaradas como os principais esforços em matéria de defesa no combate a essas ameaças. Os autores também demonstram que a melhor estratégia para incentivar a pesquisa em vacinas está centrada na colaboração internacional entre corporações e a 
academia, pois o compartilhamento de informações é crucial para a celeridade dos resultados nessa área.

A partir disso, Hoyt e Brooks (2004) problematizam a questão do investimento no desenvolvimento de novas vacinas como uma estratégia de fortalecimento da defensa e da saúde pública. Segundo eles, os mesmos recursos e tecnologias necessárias para pesquisar, desenvolver e aprimorar vacinas podem ser utilizados para produzir armas biológicas (HOYT, BROOKS, 2004; FRASER, DANDO; 2001). Logo, as inovações na área de biotecnologia servem tanto para o combate às armas biológicas quanto para a sua produção. Além disso, se tem discutido sobre a hipótese do uso da biotecnologia para produzir armas biológicas a partir de novos agentes geneticamente modificados especialmente para esse propósito (AKEN; HAMMOND, 2003; FRASER, DANDO; 2001). Esse tópico foi assunto do relatório "The Darker Bioweapons Future", publicado pela CIA, em 2003. Para responder a esse dilema, os autores sugerem a harmonização da regulamentação de pesquisas na área de biotecnologia, a fim de criar um regime internacional nessa matéria que seja consistente o suficiente para viabilizar os avanços científicos para a produção de vacinas, ao mesmo tempo em que reduzindo o risco de uso dessa tecnologia para outros fins ${ }^{19}$.

Em 2004, o Congresso dos EUA aprovou a proposta de lei do então presidente George W. Bush para o incremento da segurança contra doenças infecciosas e bioterrorismo, conhecido como Projeto Bioshield (WHITE HOUSE, 2004). O ato, elaborado na esteira dos recentes incidentes com antraz e na conjuntura da "guerra ao terror" (WHITE HOUSE, 2014). instaurada após 11 de setembro de 2001, provê recursos e autoridades para a aquisição e desenvolvimento de insumos e medicamentos para responder ("medical contermeasures", MCMs, no original em inglês) a eventuais ataques de ordem química, biológica, radiológica ou nuclear (ameaças CBRN, na sigla em inglês). Ao todo, o projeto garantiu 5.593 bilhões de dólares disponibilizados ao longo de 10 anos - de 2004 a 2013 - para incentivar o mercado farmacêutico para pesquisa e produção de MCMs (KADLEC, 2013).

Esse projeto instaurou uma nova política administrativa para aumentar a defesa contra ameaças biológicas nos EUA em pelo menos três frentes. Na primeira delas, simplificou os processos de licitação para contratos de compra e/ou pesquisa de produtos contra ameaças CBRN, aumentando as verbas públicas disponíveis para as mesmas de 100 mil para 25

\footnotetext{
${ }^{19}$ Além da problemática envolvida na produção de armas biológicas, outro problema que surge dada a falta de uma regulamentação internacional consistente nesse âmbito refere-se aos riscos de acidentes em laboratórios onde cientistas manipulam agentes patogênicos. Em março de 2014, esse tema foi capa da Newsweek: "The Cure May Kill You: The only thing scarier than bio-warfare is the antidote", texto disponível em: http://mag.newsweek.com/2014/03/21/bioerror-bio-error-labs-bio-warfare-bioterror.html
} 
milhões de dólares. A segunda linha de ação instaurou a reserva de mercado desses produtos, garantindo às empresas produtoras a sua compra para a expansão do Estoque Estratégico Nacional, inclusive de drogas ainda que ainda não haviam sido testadas ou aprovadas. Por fim, a lei suspendeu padrões tradicionais de testagem, permitindo que o Departamento de Saúde e Serviços Humanos (DSSH) dos EUA utilizasse vacinas, medicamentos e outros insumos sem a aprovação do Food and Drug Administration (FDA, órgão público do governo dos EUA que garante a segurança sanitária de serviços de saúde, insumos e medicamentos) em caso de emergência ${ }^{20}$ (GOTTRON, 2009). Até janeiro de 2013, foram firmados 11 contratos entre o DSSH e 7 empresas farmacêuticas, no valor de 2.68 bilhões de dólares (KADLEC, 2013). Esses contratos possibilitaram a compra de 17 MCMs contra antraz, varíola, toxina botulínica, agentes radiológicos, entre outros para estocagem. O projeto foi estendido até 2018 com a aprovação do "Pandemic and All Hazards Preparedness Act" em março de 2013 (UNITED STATES DEPARTMENT OF HEALTH AND HUMAN SERVICES, 2013).

Há uma série de problemas relacionados ao desenvolvimento do Projeto Bioshield. Em primeiro lugar, o caráter emergencial, no contexto de crise após 11 de setembro e dos ataques por meio das cartas com antraz, em 2001, coloca preocupações quanto à forma como a lei foi aprovada. Esse parece ser um caso em que uma medida extraordinária (aprovação do projeto) foi tomada em relação às ameaças percebidas (bioterrorismo), apontando para a securitização bem-sucedida do objeto (MCMs), de acordo com a teoria da securitização, como será discutido posteriormente.

Além disso, uma série de preocupações foi levantada quanto aos desdobramentos da flexibilização dos padrões de segurança que a lei estipula. Sérias implicações podem advir, por exemplo, do uso de medicamentos, vacinas e outros insumos médicos sem a prévia a sua testagem e aprovação. Além disso, o investimento feito pelo DHHS para pesquisa com agentes patológicos de alto risco, fez crescer o número de laboratórios de nível de biossegurança 3 e 4 (BSL, "biosafety levels",21, no original). Em relatório emitido por uma agencia de controladoria e supervisão do governo americano em 2013, devido à falta de padrões e normas para esse o funcionamento desse tipo de instituição, percebeu-se que o aumento do número desses laboratórios ocorreu sem a devida supervisão por parte do governo - aumentando consideravelmente os riscos de acidentes e de liberação de agentes patológicos

\footnotetext{
${ }^{20} \mathrm{O}$ uso emergencial de produtos não-aprovados foi permitido, por exemplo, para quatro produtos em 2009 durante pandemia do H1N1 (GOTTRON, 2009).

${ }^{21}$ Para mais informações sobre os níveis de biossegurança laboratorial, acessar:

<http://www.cdc.gov/training/QuickLearns/biosafety/ >
} 
nesses locais (UNITED STATES GOVERNMENT ACCOUNTABILITY OFFICE, 2013; SCUTTI, 2014).

Mais preocupante ainda são os riscos associados à natureza das pesquisas empreendidas no âmbito do Projeto Bioshield. Em diversas ocasiões, cientistas trabalharam com a criação de novas cepas de vírus especialmente modificados para produzir armas biológicas, para então desenvolver vacinas. Essa modalidade de pesquisa que procura desenvolver a proteção para agentes patológicos que sequer existem, é realizada com financiamento do governo norte-americano sob diversos contratos celebrados com a DHHS (FRANZEN, 2013a; FRANZEN, 2013b; SCUTTI, 2014).

Parece não haver claro consenso acerca dos resultados dos dez anos do Projeto Bioshield analisado em sua totalidade. Se, por um lado, a flexibilização das normas de licitações e a reserva de mercado estipulada pelo ato são incentivos massivos às indústrias farmacêuticas, por outro, muito discute-se que a administração dos recursos não foi estrategicamente realizada e por isso falhou em produzir MCMs contra as principais ameaças patológicas (SHANE, 2004).

\subsection{Abordagens revisoras}

\subsubsection{Abordagem securitizadora}

A partir da década de 1980, o campo de estudo das Relações Internacionais abrigará uma nova ordem de debates de caráter ontológico e epistemológico. Talvez a mais significativa evidência desse novo debate seja a respeito do alargamento do conceito de segurança internacional (KRAUSE; WILLIAMS, 1996; BALDWIN, 1997; WALT, 1991). Essas novas revisões desse conceito buscarão dialogar com a sua concepção clássica, que encontrou proeminência e aplicação científica no bojo do pensamento neorrealista.

A corrente liberal-institucionalista é a primeira a propor o alargamento do conceito de segurança, passando a compreender também questões relativas ao meio-ambiente (MATHEWS, 1989) e ameaças domésticas (ULLMAN, 1983). Para Keohane (1984), a segurança não era mais temática única ou prioritária na agenda internacional, como pressupunha o neorrealismo, e a cooperação entre os Estados era capaz de modificar os interesses e expectativas desses atores em relação à questão militar, devido ao alto custo relativo dessa atividade. Segundo David Fidler (2002), a segurança nesse caso deriva dos 
esforços cooperativos dos Estados para manter a paz e a segurança coletivamente, e, por isso, é entendida como "segurança comum".

Em sequência, outra contribuição consistente para os estudos de segurança, e para uma redefinição do conceito de segurança internacional, é trazida pela escola construtivista das Relações Internacionais. Segundo Buzan (1997), a produção desse campo acadêmico varia no espectro epistemológico com contribuições pós-modernas e críticas (HANSEN, 1997; KRAUSE, 1998), até posições positivistas (WENDT, 1999). O que une essa corrente é o entendimento do mundo e dos fatos enquanto construção social: o que nos leva a entender inclusive o conceito de segurança também enquanto fruto da interação social, e não como um dado concreto. $\mathrm{Na}$ análise da literatura empreendida neste capítulo, as proposições de alargamento do conceito de segurança pela estrada do construtivismo são colocadas em duas abordagens distintas: na abordagem securitizadora, objeto de discussão desta sessão, e na abordagem crítico-sociológica, que será tratada posteriormente.

A nomenclatura escolhida para a abordagem da relação entre doenças infecciosas e segurança internacional discutida nesta sessão se apropria do termo da Escola de Copenhague acerca da teoria da securitização (WEAVER, 1995; BUZAN, 1997; BUZAN, WEAVER, 2003; BUZAN et al., 1998). Parte significativa dessa escola considera que as ameaças à segurança são socialmente construídas, entre outros fatores, por meio do discurso, diferentemente das abordagens clássicas, que as vinculam às ameaças objetivas, conforme é do entendimento da abordagem tradicional. Para Ole Waever (2000, p.251), isso significa entender segurança internacional como um processo que se dá por meio de um

ato de fala em que o ator securitizador designa uma ameaça como sendo um objeto referente específico e a declara uma ameaça existencial, o que possibilita o uso de meios extraordinários para isolá-lo. O problema é securitizado - se torna um problema de segurança, parte do que é segurança - se a plateia aceita essa proposição e, então, concede ao ator securitizador o direito de violar regras que anteriormente deveria respeitar.

A importância da teoria da securitização para o entendimento da segurança internacional é evidente em, pelo menos, duas características: em primeiro lugar, a abordagem multissetorial, a base teórica para o alargamento da concepção de segurança. Em segundo lugar, a teoria argumenta que o processo de securitização se dá por meio do ato de fala (BUZAN et al., 1998; WAEVER, 2000), o que advoga pela compreensão da segurança enquanto um processo de construção social de significados por um ator interessado em securitizar um objeto. Compreender essa relação sob esse prisma estipula necessariamente o reconhecimento de que a ameaça colocada pelas doenças infecciosas não são assuntos 
"naturais" da segurança nacional ou da defesa (como percebe a abordagem tradicional), mas, sim, construções sociais desenvolvidas e apropriadas pelos atores interessados nessa dinâmica e responsáveis por essa agenda. Por isso, a abordagem securitizadora é fundamentalmente distinta da tradicional, pois nela há a ênfase na dimensão processual da relação entre doenças infecciosas e segurança.

Ao acessar a bibliografia que analisa o nexo entre saúde global e segurança internacional a partir do modelo analítico da teoria da securitização, percebe-se que esses autores fazem uso desse marco teórico de maneira bastante diversificada com relação quer à precisão conceitual, quer ao método empregado. Não obstante, é possível identificar dois pontos em comum que caracterizam essa abordagem. Primeiramente, parece ser consensual que, conforme defende Maclean (2008), a securitização da agenda da saúde está ocorrendo como o resultado de mudanças associadas à globalização, que alteram a natureza ou o grau das ameaças percebidas pelos atores.

Em segundo lugar, essa abordagem está preocupada com as dimensões normativas da securitização da saúde global - em especial, das doenças infecciosas. Nessa linha, McInnes e Lee (2005) avaliam os resultados de uma bem-sucedida securitização da saúde. Por um lado, há o entendimento de que securitização pode aumentar a atenção e o interesse da comunidade internacional sobre o tema ao destacar a posição de prioridade na agenda política internacional conferida ao objeto (SINGER, 2002). Por outro, há a preocupação de que essa atenção passe a se concentrar nos círculos militares, de inteligência e de defesa nacional, afastando, dessa forma, a matéria de seu conteúdo originário, impedindo, assim, seu tratamento de maneira especializada (ELBE, 2006; O’MANIQUE, 2006).

Ao abordar os processos de securitização da saúde global, Kelle (2007) argumenta que movimentos de securitização dessa agenda são impetrados em dois espaços discursivos distintos: na OMS e na Convenção sobre Armas Biológicas (BWC). Esses ambientes multilaterais se ocupam das agendas, respectivamente, da saúde pública internacional e do controle da produção, distribuição e uso de armas biológicas. O ponto de intersecção entre esses dois espaços são as doenças infecciosas.

$\mathrm{O}$ autor argumenta que o processo de securitização contribuiu para o fortalecimento do Estado como um agente central no provimento da saúde pública internacional. Isso é evidenciado pelo fato de que, em todos os contextos de securitização da saúde pública, o objeto referente é a saúde pública internacional - e não global - o que enfatiza o papel central dos Estados nessa agenda. No processo de revisão do Regulamento Sanitário Internacional (RSI), por exemplo, ficou decidido que são os Estados os responsáveis por cooperar com a 
OMS nas áreas de vigilância e resposta e por estipular pontos focais nacionais para a implementação dessa norma.

Kelle (2007) também argumenta que, nos processos de securitização, a OMS tem desempenhando três papeis distintos. No primeiro caso, como o objeto referente, a ser securitizado no Painel de Alto Nível sobre Ameaças, Desafios e Mudanças do Secretário-geral das Nações Unidas (2004), em que se aponta para a necessidade de cooperação entre a OMS e o Conselho de Segurança das Nações Unidas no estabelecimento de medidas de quarentena em casos extremos colocados pela ameaça de novas doenças infecciosas ou pela liberação intencional de agentes patogênicos.

Já no processo de revisão dos RSI, a OMS é utilizada como espaço discursivo no qual os atores empreendem movimentos de securitização. Kelle (2007) afirma que alguns países defenderam a necessidade de incluir no Regulamento provisões para respaldar a coleta de informações com relação a armas químicas, biológicas, radiológicas e nucleares. Por fim, todas as referências às armas químicas e radiológicas foram deixadas de fora do novo RSI por isso estar além do mandato da OMS (KELLE, 2007, p.227).

O terceiro papel desempenhado pela OMS foi de agente securitizador da saúde pública. Nesse último caso, as tentativas de securitizar a saúde pública empreendidas pela OMS no processo de revisão do RSI visaram promover a compreensão de segurança em saúde como segurança humana, evitando caracterizá-la como um assunto de segurança em sua conotação tradicional (KELLE, 2007, p.230). O autor afirma que a OMS percebeu, ao promover a securitização no segundo caso, que estaria penetrando o escopo da BWC e comprometer-se na verificação do uso de armas biológicas significaria envolver-se numa atividade politicamente sensível, arriscando sua neutralidade.

Kelle (2007) conclui afirmando que a saúde pública internacional até agora só foi parcialmente securitizada. Ele se justifica com base na análise do orçamento da Organização: o montante do orçamento destinado à área de trabalho relativa às epidemias de ocorrência intencional na OMS - a que mais se aproxima da área de atuação da BWC - não faz parte do orçamento regular da instituição, sendo apenas constituído de fundos específicos provenientes de alguns Estados. Isso faz com que a securitização dessa matéria seja de mais fácil reversão, pois depende do interesse de países interessados nesse assunto.

Jin e Karackattu (2011) defendem que a OMS contribuiu para securitizar as doenças infecciosas na primeira década do século XXI, apesar de operar historicamente como uma instituição provedora de recursos técnicos, de cunho humanitário e neutro. O agravamento da epidemia de HIV/AIDS, a crise de 2003 da SARS, a pandemia de gripe aviária e os ataques de 
antraz em 2001 são listados como os fenômenos que contribuíram para a reorientação dos posicionamentos da OMS nesse período. Essa reorientação, segundo os autores, ocorre como forma de a OMS reivindicar e garantir seu poder em matéria da governança global de doenças infecciosas $^{22}$. Essa evidência é discutida por Davies (2008, p.297) ao explicar porque a OMS investe na implantação de um sistema de vigilância epidemiológica global para atender os interesses dos países ocidentais.

Esses movimentos de securitização das doenças infecciosas são percebidos em dois momentos. Primeiro, a OMS tem exercido atos de fala enquadrando as doenças infecciosas como ameaças à segurança (JIN; KARACKATTU, 2011, p.182). Esses podem ser encontrados, por exemplo, nas diversas declarações públicas realizadas desde 2000 pela instituição abordando a questão das doenças infecciosas, no relatório intitulado "Estratégia da OMS para Segurança da Saúde Global: alerta e resposta às epidemias”, no relatório de 2007 "Um Futuro mais seguro: Segurança da Saúde Pública Global no Século XXI”, bem como em uma série de declarações de diretores da organização.

O segundo fato que demonstra os esforços de securitização da matéria em questão é destacado em algumas medidas extraordinárias tomadas pela OMS ao lidar com a governança das doenças infecciosas. Jin e Karackattu (2011) discutem que a organização, numa ação sem precedentes e sem o respaldo legal necessário, na ocasião da crise de SARS em 2003, emitiu alertas globais sobre viagens a Beijing e Toronto, sem o consentimento prévio da China e Canadá.

Esses esforços de securitizar a agenda das doenças infecciosas colocaram a OMS em face de uma encruzilhada política, segundo os autores: se, por um lado, a organização procura garantir sua autoridade em matéria da governança das doenças infecciosas - angariando, assim, maior quantidade de recursos internacionais para tanto -, por outro, ela também tenta manter-se afastada de assuntos sensíveis da política internacional para preservar seu papel humanitário, técnico e sua posição neutra.

Em pelo menos três assuntos esse dilema tem se materializado dentro da gestão da OMS, gerando clivagens entre os Estados-membros e divergência de interesses. O primeiro deles diz respeito ao papel da OMS na implementação da Convenção de Armas Biológicas. Após a defesa por parte dos EUA e seus aliados de que a OMS desempenhasse um papel de líder no combate ao bioterrorismo internacional, diversos países (em especial os em

\footnotetext{
${ }^{22}$ Finnemore e Barnett (2004), no livro "Rules for the World: International Organizations in Global Politics", defendem a ideia de que as organizações internacionais procuram determinar agendas e normativas internacionais como forma de estabelecer seu poder institucional.
} 
desenvolvimento) reagiram argumentando que isso levaria a organização a se envolver em problemas relativos à segurança nacional, gerando complicações na manutenção de sua posição de neutralidade (CHECK, 2005; KELLE, 2007).

O segundo aspecto do dilema enfrentado pela OMS diz respeito ao seu programa de vigilância epidemiológica. Em 2000, foi criada pela organização a "Global Outbreak and Response Network" (GOARN) para coordenar os recursos técnicos para identificar, acompanhar e responder às novas doenças infecciosas de importância internacional. Os países em desenvolvimento têm reconhecido que essa rede e o programa de vigilância epidemiológica da OMS priorizam os interesses de segurança dos países desenvolvidos, dificultando a colaboração daqueles com a organização e, logo, minando a eficiência do próprio sistema de vigilância.

Em terceiro lugar, os autores levantam a ambiguidade das implicações de securitizar as doenças infecciosas. Os países em desenvolvimento não se identificam com a maneira com que os países desenvolvidos investem na securitização como uma forma de garantir sua segurança nacional. Ademais, a securitização das doenças infecciosas é vista por alguns grupos como uma normalização do uso intrusivo de vigilância externa, acompanhado da revogação da soberania dos países em desenvolvimento em diversas áreas políticas ligadas ao tema (JIN; KARACKATTU, 2011, p.185).

Davies (2008) procura compreender como a comunidade internacional - especialmente os Estados ocidentais e a OMS - tem construído a noção de que as doenças infecciosas são ameaças à segurança. Davis argumenta que os países desenvolvidos iniciaram o processo de securitização das doenças infecciosas a partir os anos 1990. O bioterrorismo, o aumento dos fluxos de pessoas e bens com a intensificação da globalização, os ataques com antraz em 2001, a crise de SARS e do H5N1 em 2003 estão entre os listados pela autora que propulsionaram o processo de securitização encabeçado pelos EUA, Austrália, Canadá e pela União Europeia (DAVIES, 2008, p.299). Ao se preocuparem com as ameaças e riscos colocadas por essas a seus cidadãos, esse conjunto de países incentivou as medidas de fortalecimento da vigilância epidemiológica em escala global e também da capacidade de conter a propagação dessas doenças. Segundo a autora, esses mecanismos funcionam como uma reposta aos temores desses Estados, mais do que instrumentos de prevenção do surgimento de epidemias no mundo.

Nesse sentido, o papel de liderança e autoridade que a OMS desempenhou nessa agenda foi possível devido ao consentimento desses países. Por isso, a criação de mecanismos globais de vigilância priorizam a proteção dos Estados ocidentais frente à ameaça colocada 
pela propagação das doenças infecciosas entre fronteiras. Procurando responder à securitização das doenças infecciosas e também aos interesses dos países ocidentais, a OMS atuou em duas frentes: conduzindo e liderando o processo de revisão dos regulamentos internacionais que davam forma ao regime de contenção das epidemias e investindo no sistema global de vigilância epidemiológica sob seus auspícios.

A autora identifica três razões que ajudam a compreender o interesse da OMS no enquadramento das doenças infecciosas como um assunto de segurança internacional. Primeiramente, para a OMS, securitizar a matéria daria maior visibilidade às doenças infecciosas como um todo, o que provavelmente traria benefícios para o aprofundamento dessa agenda e de suas políticas globais. Em segundo lugar, aumentar a atenção e a preocupação com a propagação das doenças infecciosas incentivaria a percepção de que esse é um assunto que interessa a países desenvolvidos e em desenvolvimento. Logo, doenças infecciosas seriam entendidas como uma ameaça comum. Por fim, a OMS investiu na securitização do tema como forma garantir sua autoridade e participação nesse âmbito, prevenindo que os Estados ocidentais criassem mecanismos individuais e nacionais de vigilância das doenças infecciosas. Todos esses motivos, segundo Davies, sustentam o desenvolvimento do principal programa de controle das epidemias da OMS, o GOARN.

Securitizar as doenças infecciosas trouxe benefícios tanto para os Estados ocidentais quanto para a OMS, segundo Davies. Em primeiro lugar, delegar a responsabilidade para lidar com a ameaça das doenças infecciosas para a OMS beneficiou os Estados ocidentais, pois a atuação da Organização é revestida de um caráter de neutralidade - e também pelo sua função de ajuda humanitária, como argumentam outros autores - perante diversos países, especialmente aqueles avessos à intervenção ocidental em seus assuntos domésticos. Por outro lado, a OMS se beneficiou desse processo ao fortalecer seu papel normativo e sua autoridade sobre essa agenda, demonstrando ser um ator fundamental da saúde global.

\subsubsection{Abordagem da "health security"}

A abordagem da health security procura compreender a relação entre doenças infecciosas e segurança internacional destacando o impacto daquelas sobre a estabilidade doméstica dos Estados. Dessa forma, a teoria da health security advoga que as doenças infecciosas representam riscos à segurança ao ameaçarem a estabilidade das sociedades, agindo "por de dentro dos Estados". Por isso, diferentemente da abordagem tradicional, há o apreço pela dimensão social dos impactos das epidemias em um país. Nesse sentido, defende 
Prescott (2007, p.3), as doenças infecciosas "colocam um desafio para a coesão social, para o desempenho econômico e para a legitimidade política" das sociedades. Por isso, essa abordagem enfatiza o foco nas capacidades dos Estados no combate e resposta às doenças infecciosas como fatores fundamentais para a consecução e garantia da segurança doméstica, regional e global.

As bases conceituais que informam uma primeira sistematização do campo de estudos da health security foram propostas por Price-Smith (2002) no livro "The Health of Nations". Ao reconhecer que a propagação global das doenças infecciosas não ameaça propriamente a espécie humana, mas sim a prosperidade e estabilidade das sociedades, o autor procura compreender o impacto das doenças infecciosas sobre a capacidade estatal. Price-Smith defende que altos índices de doenças infecciosas podem trazer consequências severas para economias, instituições políticas, contingentes militares, sistemas educacionais, entre outros (YOUDE, 2005).

Segundo a teoria proposta por Price-Smith, as epidemias causadas por doenças infecciosas constituem ameaças diretas ao poder do Estado na medida em que comprometem a prosperidade e desestabilizam seu ambiente politico doméstico, bem como as relações com outros Estados. Buscando sistematizar como se dá essa dinâmica, o autor argumenta que o risco colocado pela propagação de um agente patogênico para um Estado depende de quatro fatores: letalidade; transmissibilidade; produção de medo; e, geração de prejuízos econômicos (PRICE-SMITH, 2009).

Nesse modelo explicativo, o agente patogênico causador da doença infecciosa em questão é a variável independente. Uma série de fatores pode afetar a ocorrência e o agravamento da propagação desse agente infeccioso como, por exemplo, conflitos armados, mudança climática, mal-uso de antibióticos, fome, desastres naturais e aumento no trafego e comércio em escala global. Esses fatores são variáveis intervenientes chamados pelo autor de "amplificadores de doenças"23 (PRICE-SMITH, 1999, p.433).

As epidemias de doenças infecciosas impactam a capacidade do Estado nas dimensões da economia e da governança política. No domínio econômico, elas afetam a estabilidade doméstica dos Estados ao afligirem a população trabalhadora, que, geralmente, pertence ao estrato social com menor poder aquisitivo e é, portanto, mais vulnerável a doenças infecciosas. Em um caso extremo, o comprometimento da força trabalhadora afeta a produtividade da economia ao gerar o aumento dos gastos com substituição de pessoal. A

\footnotetext{
23 “disease amplifiers", no original em inglês.
} 
propagação de doença infecciosa em larga escala também gera mudança nos padrões de consumo ao forçarem as famílias - especialmente as mais pobres - a redistribuírem seus orçamentos no esforço de aquisição de tratamentos médicos para a doença (PRICE-SMITH, 1999). Desafio semelhante acomete os governos que são levados a realocar recursos públicos de setores mais produtivos da economia para combater a propagação das doenças infecciosas, o que compromete o crescimento econômico futuro (PRESCOTT, 2007). Ademais, os prejuízos à economia também podem se dar devido às reduções do faturamento do setor turístico, especialmente naquelas regiões em que essa é uma atividade economicamente relevante.

Os altos índices de incidência de doenças infecciosas comprometem a governança política em um Estado, pois estão associados a fatores como o aumento da pobreza, da mortalidade e morbidade, migração e estresse psicológico (PRICE-SMITH, 1999, p.436). É nesse sentido que Prescott (2007, p.2) afirma que "a ocorrência de uma nova epidemia pode ser indicativo de, ou exacerbada pela, governança ineficiente em nível doméstico ou internacional". Essa é a cadeia causal central para a abordagem da "health security", no entendimento da relação entre doenças infecciosas, estabilidade interna e segurança. As tensões sociais que se instauram nesse quadro de crise doméstica são um desafio para a manutenção da legitimidade dos governos e para o bom funcionamento das instituições públicas (PRICE-SMITH, 1999). Nesse cenário, o fardo colocado pela carga das doenças infecciosas que afligem países abre caminho para o surgimento de Estados frágeis e/ou falidos, os quais não possuem os recursos financeiros e institucionais necessários para reagir à crise e que, por isso, colocam em risco a manutenção da segurança no âmbito interno. É no desenrolar dessa dinâmica que o impacto causado pelas epidemias em um Estado, dirimindo sua capacidade interna, pode extrapolar fronteiras nacionais e gerar externalidades para o âmbito regional e/ou global.

Para além dos riscos à segurança internacional apresentados acima, muito se discute também sobre o desafio colocado pelo surgimento dos Estados frágeis e/ou falidos (GIORGETTI, 2013). Nesse âmbito, Chretien (2011) examina o envolvimento das forças armadas dos EUA em ações de promoção da saúde global desde 11 de setembro. A preocupação dos EUA com o risco colocado pelos Estados frágeis e falidos, que era crescente desde a década de 1990, foi intensificada após os ataques terroristas em 2001 e, então, formalizada como na forma de uma política de segurança nacional, com a publicação da Estratégia de Segurança Nacional em 2002 (WHITE HOUSE, 2002). Nesse processo, o Departamento de Defesa (DOD) daquele país investiu na promoção da assistência em saúde 
em diversos países, visando reduzir a pobreza, alterar percepções negativas sobre os EUA e reverter outras condições socioeconômicas que possibilitassem o surgimento de grupos extremistas e violentos naquelas sociedades (CHRETIEN, 2011, p.1). Em 2010, o DOD estabeleceu a categoria de "operações de estabilidade médica" para sistematizar as ações em prol do fortalecimento das capacidades dos setores de saúde de outros países. Apesar de o envolvimento militar dos EUA em diversas regiões do mundo para promoção da saúde não ser um fenômeno novo, Chretien argumenta que, recentemente, essas atividades incorporaram o componente da estabilização dos Estados frágeis.

O fenômeno do envolvimento dos setores militares dos EUA em ações de promoção da saúde em outros países pode ser compreendido no âmbito da abordagem tradicional da relação entre doenças infecciosas e segurança internacional, uma vez que enfatiza as noções de segurança nacional e defesa. Por outro lado, esse fenômeno também dialoga com a abordagem da "health security", pois considera a estabilidade doméstica em matéria de saúde pública um fator importante para a segurança.

Segundo Price-Smith (1999), altos índices de incidência de doenças infecciosas geram externalidades para o sistema internacional. Primeiramente, os custos econômicos que as doenças infecciosas causam aos Estados podem comprometer o desenvolvimento de alguns países, o que, por sua vez, reduz a prosperidade global. Além disso, a economia desses países também pode ser afetada em decorrência de embargos econômicos a bens produzidos nas regiões onde há evidência das epidemias, como foi o caso da carne de frango exportada por Hong Kong à época da crise de gripe aviária. Em segundo lugar, apropriando-se da teoria da aversão social ao risco (KASPERSON et al., 1989), o autor defende que as epidemias contribuem para a adoção de comportamentos irracionais, o que, por sua vez comprometem as relações entre países e culturas diferentes.

\subsubsection{Abordagem da segurança humana}

A quarta abordagem que procura compreender como as doenças infecciosas são relevantes em termos de segurança internacional está articulada em torno da concepção de segurança humana. Esse conceito foi proposto em 1994 na publicação do Human Development Report, do Programa das Nações Unidas para o Desenvolvimento (PNUD), e, em síntese, identifica o indivíduo como o referente adequado da segurança internacional, e não os Estados, como fazem as perspectivas clássicas e/ou tradicionais do campo. A proposta dessa nova dimensão de segurança é, antes de qualquer coisa, um esforço de contraposição da 
reificada ideia de que segurança internacional diz respeito ao potencial de conflito entre Estados e às ameaças às suas fronteiras (UNITED NATIONS DEVELOPMENT PROGRAMME, 1994). Com a adoção desse novo conceito, seus proponentes e posteriores adeptos procuram chamar a atenção para a necessidade de considerar os indivíduos inseridos em contextos de vulnerabilidade e risco - sejam eles de ordem ambiental, econômica, social ou política - nas dimensões de segurança internacional. Por isso, a segurança humana é um conceito de aplicação acadêmica com conotação política.

De acordo com o relatório do PNUD, a segurança humana é um conceito universal, centrado nas pessoas, cujos componentes são interdependentes. Apesar de o relatório não trazer uma definição direta e explícita do termo, alguns autores esboçaram desde então algumas conceituações. Segundo Sen (2000, p.1), a segurança humana diz respeito à habilidade de "levar uma vida sem ter a sobrevivência ameaçada ou a dignidade prejudicada". Para Maclean (1998), o conceito refere-se à segurança do individuo em seu meio, comunidade ou ambiente. Enfatizando a dimensão socioeconômica, King e Murray (2001, p.585) definem segurança humana como "o número de anos de vida futura passados fora do estado de "pobreza generalizada"”.

A segurança humana envolve duas dimensões. Primeiramente, ela diz respeito à proteção contra ameaças crônicas que acometem as sociedades, tais como "fome, doenças e repressões". Em segundo lugar, o conceito refere-se à proteção contra "perturbações súbitas ou nocivas dos padrões da vida cotidiana" (UNITED NATIONS DEVELOPMENT PROGRAMME, 1994, p.23).

Diversos autores reconhecem a influência que o conceito de segurança humana teve sobre desenvolvimento da teoria da "health security". Contudo, na organização das abordagens da relação entre doenças infecciosas e segurança internacional proposta neste capítulo, entende-se que essas sejam perspectivas essencialmente distintas, apesar de reconhecer sua possível complementariedade. Segurança humana se distingue da "health security" na medida em que, para a primeira, o foco dos riscos associados às epidemias, por exemplo, recai necessariamente sobre a vida dos indivíduos. Diferentemente, a abordagem da "health security", apesar de não negar essa ameaça, preocupa-se muito mais nos impactos e desenvolvimentos desse mesmo fenômeno num nível societal e organizacional, focando nas capacidades dos Estados e, consequentemente, no sistema internacional composto por eles.

Nesse sentido, é evidente a abrangência instrumental e a variedade temática contidas nessa concepção de segurança humana. Isso fez com que o conceito ganhasse aplicação em diversas agendas da política internacional: direitos humanos, meio-ambiente, segurança 
trabalhista, reconstrução das capacidades estatais, etc. No caso da abordagem da relação entre segurança e doenças infecciosas proposta aqui, as contribuições informadas pelo conceito de segurança humana priorizarão a análise desse fenômeno como parte da relação mais abrangente entre saúde global e segurança. Isso se deve a dois motivos.

O primeiro deles consiste no esforço de evitar a conotação hegemônica que o estudo das doenças infecciosas como um assunto de segurança passou a ter, conforme é demonstrado pela abordagem securitizadora. Em segundo lugar, como indica a própria noção de segurança humana, não há como abordar doenças infecciosas sem levar em consideração outros fatores econômicos, políticos e sociais que afligem a segurança dos indivíduos ao comprometerem sua saúde. A segurança humana advoga em favor de uma concepção holística de riscos e ameaças e, por esse motivo, a abrangência do conceito de segurança humana terá reflexo sobre a abordagem da questão das doenças infecciosas como segurança, incorporando esse tema na agenda geral da saúde global.

Para Davies (2010), a concepção de segurança humana faz parte da perspectiva globalista da política internacional de saúde global. Segundo a autora, ao advogar contra o paradigma da centralidade do Estado nas Relações Internacionais, essa perspectiva é a que se preocupa em compreender a saúde não somente no tocante à contenção de doenças entre fronteiras ${ }^{24}$. Segundo a autora, a perspectiva globalista propõe que a agenda da saúde global, ao reconhecer a pluralidade de atores envolvidos nesse campo, entenda o indivíduo como o referente da segurança, e, consequentemente, objetive a promoção da "saúde para todos", que é a garantia dos mesmos recursos e acesso à saúde para as populações. Dessa forma, o globalismo nesse contexto incorpora noções de justiça, equidade, eficiência e ordem.

Na mesma linha, Maclean (2008), explorando a relação entre saúde e segurança, argumenta que a securitização da saúde está levando não só a mudanças no entendimento quanto à natureza das ameaças percebidas pelos atores mas também quanto aos conceitos que buscam compreendê-las. Dentre a diversidade de propostas teórico-conceituais existentes na literatura para abordar o tema, a autora defende o conceito de segurança humana argumentando que, em primeiro lugar, a garantia de segurança na ordem global contemporânea requer que sejam priorizadas a necessidades dos indivíduos (MACLEAN, 2008). Além disso, a autora argumenta que, ao invés de causar inoperância, a abrangência do conceito de segurança humana é necessária como ponto de partida para elucidar as relações

${ }^{24}$ Essa ideia aproxima-se ao que Fidler (2004, p.799) chamou de "governança horizontal dos germes". 
complexas entre a pluralidade de atores, estruturas, formas de governança e políticas da agenda da saúde global.

Segundo Pereira (2008), o conceito de segurança humana apresenta-se como uma doutrina emancipatória, pacifista e em prol dos direitos humanos. No entanto, argumenta o autor, ao analisar a securitização das doenças infecciosas, os países ocidentais tem se apropriado desse conceito nas tentativas de securitização do tema como forma de reforçar seu poder hegemônico liberal no pós-Guerra Fria (PEREIRA, 2008). Torna-se evidente, então, o problema da aplicação da segurança humana: sua ambivalência ao incorporar duas agendas conflitantes e provavelmente de difícil conciliação, a saber, segurança e direitos humanos.

\subsubsection{Abordagem crítico-sociológica}

A abordagem crítico-sociológica do entendimento das doenças infecciosas como tema da segurança internacional procura enfatizar os aspectos sociológicos imbuídos nessa relação. Conforme proposto aqui, essa abordagem visa elucidar como os contextos sociais afetam a dinâmica das doenças infecciosas. Apresentando um exemplo radical na defesa desse argumento, Farmer ressalta a ideia da "sociogênese das doenças infecciosas" (FARMER, 1996, p.260). Segundo ele, estudos sobre a mutação microbiana tem demonstrado que ações humanas tem tido papel mais importante no aumento da patogenicidade e da resistência contra antibióticos desses agentes infecciosos do que outro fatores de ordem biológica, genética ou natural. Isso ajuda a compreender, segundo Farmer, como variáveis associadas à ação humana e às dinâmicas das sociedades estão intrinsecamente relacionadas com a ocorrência e distribuição das doenças infecciosas.

Dessa forma, a abordagem crítico-sociológica incorpora dois componentes. O primeiro deles é o destaque às desigualdades e como essas tem impactos sobre a distribuição dos fatores de risco colocados pelas doenças infecciosas no mundo, conforme discute Farmer (1996). O segundo componente é a ênfase nas narrativas e construção de significados associados às doenças infecciosas. Ambos componentes serão analisados a seguir.

Para essa abordagem, há a necessidade de reconhecer a importância das "forças sociais de larga escala" (FARMER, 1996, p.261) que são fatores condicionantes das posições desiguais ocupadas pelos indivíduos na sociedade no contexto da propagação de doenças infecciosas emergentes. Dessa forma, Farmer (1996) advoga em favor da epidemiologia crítica. Essa abordaria a ocorrência das doenças infecciosas emergentes enfatizando o seu 
componente sociológico - estendendo-se para além dos modelos matemáticos e estatísticos tradicionais do campo.

Seria extrapolação argumentativa afirmar que a epistemologia crítica aborda o tema de como doenças infecciosas constituem temas de segurança internacional. Entende-se que ela o faz somente dentro do escopo em que a linguagem da própria epistemologia possibilita, procurando entender os "fatores de risco" na propagação das epidemias. Nesse sentido, o que se faz aqui ao propor a abordagem crítico-sociológica que tem como uma de suas bases essa vertente da epistemologia é um esforço de tradução da linguagem desse campo do conhecimento para as relações internacionais: o que seriam os riscos para a epidemiologia, as relações internacionais entenderiam sob o prisma da segurança.

Por isso, abordar essa relação a partir da contribuição de Farmer (1996) significa tratar o fenômeno das doenças infecciosas emergentes e das epidemias - tanto em relação ao seu surgimento e propagação - não como dados de fato, mas como produtos da interação social, em primeiro lugar. Farmer (1996) se vale do exemplo de três doenças infeciosas - febre hemorrágica do ebola (hoje chamada de "doença do vírus ebola"), tuberculose e HIV/AIDS para demonstrar como o contexto social associado a cada uma delas explica seu desenvolvimento epidemiológico ao longo das décadas.

Segundo o autor, a ocorrência de novas epidemias de ebola não pode ser compreendida apenas como um fenômeno de ocorrência natural, mesmo que seja sabido há quase três décadas que o filovírus causador da doença seja transmitido no contato de primatas para seres humanos. Novos casos da doença, segundo Farmer (1996), estão diretamente ligados às redes regionais de comércio e trafego de pessoas em comunidades espalhadas pelo interior do continente africano. Além disso, indivíduos pertencentes a classes sociais distintas tem chances diferentes de contrair a febre hemorrágica devido a diversos fatores engendrados nos contextos sociais: elites locais e a comunidade expatriada nas regiões de incidência da doença apresentam risco mínimo de contraírem o vírus por terem acesso a serviços médicos de alta qualidade e que seguem rígidos padrões de biossegurança.

Por outro lado, classes pobres e os profissionais de saúde que servem essa parcela da população são expostos a riscos muito maiores. Por isso, a emergência e evolução das epidemias de ebola não são randômicas (FARMER, 1996, p.262), como a alta adaptabilidade, virulência do patógeno e sua disponibilidade ecológica levaria a concluir, mas, sim, respondem aos fatores de ordem social.

Outro caso discutido por Farmer é o sobre a redistribuição dos casos de tuberculose no mundo. Até as primeiras décadas do século XX, a doença figurava entre as principais causas 
de morte em todo o globo. Com a descoberta das terapias antibióticas para combater o Mycrobacterium tuberculosis na década de 1940, deu-se início à reversão desse quadro. Contudo, apesar de as taxas da doença nos países desenvolvidos hoje serem extremamente baixas, a tuberculose permanece como uma a principal causa de morte por infecções no mundo devido à manutenção de altas taxas registradas nos países pobres (RYAN, 1993). Segundo Farmer (1996), esse quadro de desigualdade na distribuição dos casos entre os países deve-se ao fato de que, nas últimas décadas do século $\mathrm{XX}$, após o sucesso das terapias e do aumento das taxas de cura, a tuberculose perdeu espaço na agenda de prioridades da saúde pública devido à redução da sua importância clínica e epidemiológica (FARMER, 1996; MURRAY, 1991). Farmer argumenta que, apesar de a tuberculose hoje retornar à agenda na categoria de "doença infecciosa reemergente", ela esteve sempre presente entre diversas populações: “[...] o lugar onde as doenças se escondem é entre os pobres, especialmente quando os pobres são socialmente segregados daqueles cujas mortes são consideradas mais importantes" (FARMER, 1996, p.263).

As desigualdades epidemiológicas associadas às doenças infecciosas entre países desenvolvidos e em desenvolvimento é ressaltada por essa abordagem. Numa perspectiva crítica acerca da globalização no mundo contemporâneo, Sparke e Anguelov (2012) examinam as desigualdades no âmbito da saúde global que emergiram com a crise da Influenza A em 2009. Na opinião dos autores, a pandemia enfatizou como os países mais pobres, e as populações mais pobres, são facilmente responsabilizadas por doenças que tem, na verdade, características globalizantes.

Ademais, outro importante tema a ser discutido a esse respeito é o avanço tecnológico em curso na sociedade contemporânea e o modo como sua disponibilidade desigual afeta diferentemente a segurança das populações. Segundo Farmer (1996, p.265), “aqueles que mais correm o risco de contraírem doenças infecciosas emergentes geralmente não tem à disposição os benefícios do conhecimento científico de ponta”. Enfatizando a noção crítica do acesso à tecnologia, o autor prossegue: "vivemos em um mundo onde as epidemias passam facilmente pelas fronteiras - sociais e geográficas - enquanto os recursos, inclusive o conhecimento científico acumulado - são barrados nas alfandegas".

O segundo componente da abordagem crítico-sociológica, diretamente associado ao primeiro, é a ênfase na importância das narrativas. Alguns autores que analisam o fenômeno transnacional das epidemias no mundo contemporâneo, ao adotarem modelos teóricos específicos, tem ressaltado as narrativas que grupos e comunidades constroem como recursos explicativos para as crises epidemiológicas. Essas narrativas atribuem significados distintos à 
ocorrência das doenças infecciosas e, consequentemente, à forma como essas são percebidas como assuntos de segurança internacional.

Dessa forma, as diferentes possibilidades interpretar o fenômeno das doenças infecciosas no mundo é o que a abordagem crítico-sociológica traz de novo ao chamar a atenção para as narrativas. Para entender o processo pelo qual diferentes narrativas são construídas socialmente, Leach et al. (2010) recorrem ao conceito de "framing". Esse se refere aos "esquemas de interpretação" que permitem os atores sociais identificar, analisar e entender um determinado fenômeno (GOFFMAN, 1974, p.21). É por meio da diversidade desses esquemas que surgem diferentes processos cognitivos, sociais e discursivos (LEACH et al., 2010) que, por sua vez, dão origem a diferentes narrativas que contam a história do fenômeno - no caso discutido aqui, por exemplo, como surgiu, se propagou e deve ser contida uma determinada doença infecciosa.

Organismos internacionais, Estados, instituições do terceiro setor, redes e comunidades envolvidos na dinâmica da propagação transnacional das doenças infecciosas adotam processos de "framing" diferentes e propõem, dessa forma, narrativas que buscam interpretar esse fenômeno. Esses processos incorporam também a subjetividade em termos de valores e julgamentos feitos pelos atores sociais. Com isso, essa perspectiva traz a dimensão reflexiva para a compreensão das doenças infecciosas como assuntos de segurança, ao incorporar a subjetividade dos atores envolvidos nessa relação.

Wald (2008) explica como as diferentes narrativas a respeito da emergência de novas doenças são geralmente contadas de maneira com que, simultânea e consequentemente, constroem comunidades de "insiders" e "outsiders" (SPARKE \& ANGUELOV, 2012, p.727). Segundo Leach et al. (2010), diferentes narrativas sobre epidemias competem por espaço e repercussão. Por isso, a governança dessa agenda tende a ser seletiva ao priorizar uma determinada narrativa em detrimento das demais. Leach et al. (2010) afirmam que aquelas que ganham espaço geralmente são as promovidas pelas agências internacionais e pelos governos de países do Norte, e não as alternativas comunitárias, locais ou de países em desenvolvimento. Segundo Wald (2008), as narrativas hegemônicas que procuram explicar as epidemias em geral focam a atenção numa dinâmica particular das doenças - geralmente de súbita emergência e de rápida propagação - e em uma determinada modalidade de resposta para o problema - geralmente universal e que objetiva a erradicação (LEACH et al., 2010).

Numa alternativa a essa caracterização do fenômeno, as doenças infecciosas podem ser entendidas mais como endemias do que epidemias, no sentido de enfatizar a sua persistência histórica em determinadas comunidades que desenvolveram modos culturalmente 
estabelecidos de lidar com elas (LEACH et al., 2010). Os casos que exemplificam esse tipo de narrativa são os das diversas epidemias de febre hemorrágica em comunidades africanas no fim do século XX. Nessas ocasiões, os organismos internacionais envolvidos na contenção da doença não perceberam a princípio que as comunidades locais tinham um modelo próprio para explicar o surgimento, transmissão e a prevenção da doença. Foi somente com a pesquisa antropológica, que orientou a incorporação de mecanismos culturais nas políticas de resposta dos organismos internacionais, que se conseguiu conter, eficaz e eficientemente, o avanço da doença (HEWLETT; HEWLETT, 2008).

Em suma, por ter como base a epidemiologia crítica (FARMER, 1996; BREILH, 2003), a abordagem crítico-sociológica discute como as doenças infecciosas são assuntos de segurança internacional ao destacar como os seus riscos e ameaças são "distribuídos" desigualmente entre populações, regiões e países. Por outro lado, a inspiração construtivista dessa abordagem, ressalta interpretações sociológicas e antropológicas que possibilitem compreender de que forma a construção social de significados - na forma de narrativas - são fatores relevantes para abordar as doenças infecciosas como temas de segurança.

Dessa forma, em síntese, esses dois componentes da abordagem crítico-sociológica colocam em voga aspectos distributivos associados às doenças infecciosas hoje: no primeiro caso, a distribuição desigual dos riscos; e, no segundo, a distribuição dos significados socialmente construídos para interpretar o fenômeno.

\subsection{Conclusão}

As doenças infecciosas constituem uma nova dimensão da segurança internacional. Esse capítulo procurou mapear as diferentes contribuições que caracterizam essa concepção. O ponto de partida para compreender como as doenças infecciosas são um tema de segurança internacional pode ser localizado na abordagem tradicional. Com base nas acepções realistas, ao enfatizar as questões de defesa e segurança nacional, essa vertente trata o fenômeno dos surtos, epidemias e pandemias como riscos à integridade dos Estados. Por isso, para a abordagem tradicional, as DIs são entendidas como ameaças diretas à segurança do sistema internacional.

A insuficiência dessa explicação é evidenciada pela diversidade de contribuições sistematizadas nas quatro abordagens revisoras. De maneira a complementar à abordagem tradicional, essas discutem as DIs como ameaças indiretas à segurança. Para tanto, elas levam em consideração novas variáveis, enfatizam elementos diferentes da relação entre DIs e 
segurança internacional e analisam casos e temas peculiares, e, dessa forma, oferecem modelos de análise alternativos. Por isso, conforme se discutiu ao longo desse capítulo, as abordagens revisoras revelam outras facetas da relação entre DIs e segurança internacional, que não poderiam ser observadas ou compreendidas sob o prisma da abordagem tradicional. Essa sistematização pode ser sintetizada no quadro a seguir:

QUADRO 1 - Abordagens das doenças infecciosas como tema de segurança internacional

\begin{tabular}{|c|c|c|c|}
\hline Abordagem & Ênfase & $\begin{array}{l}\text { Referente da } \\
\text { segurança }\end{array}$ & Principais temas \\
\hline Tradicional & $\begin{array}{l}\text { Defesa e segurança } \\
\text { nacional }\end{array}$ & Estado & $\begin{array}{l}\text { Armas biológicas, } \\
\text { bioterrorismo, } \\
\text { envolvimento/impacto sobre } \\
\text { setores militares, campanhas de } \\
\text { vacinação e vigilância } \\
\text { epidemiológica. }\end{array}$ \\
\hline Securitizadora & Processos e discursos & Estado & $\begin{array}{l}\text { Regimes internacionais, } \\
\text { organismos internacionais, }\end{array}$ \\
\hline "Health security" & $\begin{array}{l}\text { Estabilidade e } \\
\text { prosperidade das } \\
\text { sociedades }\end{array}$ & $\begin{array}{l}\text { Estado e } \\
\text { sociedade }\end{array}$ & $\begin{array}{l}\text { Desafios às capacidades } \\
\text { nacionais, governança e } \\
\text { governabilidade, Estados } \\
\text { frágeis/falidos, }\end{array}$ \\
\hline Segurança humana & $\begin{array}{l}\text { Condições de vida dos } \\
\text { indivíduos }\end{array}$ & Indivíduo & $\begin{array}{l}\text { Acesso aos recursos e serviços } \\
\text { de saúde; direitos humanos e } \\
\text { doenças infecciosas }\end{array}$ \\
\hline $\begin{array}{l}\text { Crítico- } \\
\text { sociológica }\end{array}$ & $\begin{array}{l}\text { Desigualdades e } \\
\text { narrativas }\end{array}$ & $\begin{array}{l}\text { Indivíduos, } \\
\text { comunidades, } \\
\text { Estados e/ou } \\
\text { regiões }\end{array}$ & $\begin{array}{l}\text { Acesso às tecnologias de } \\
\text { saúde; diferentes abordagens } \\
\text { da emergência, propagação e } \\
\text { forma adequada de resposta às } \\
\text { epidemias; }\end{array}$ \\
\hline
\end{tabular}

Por isso, percebe-se que as abordagens revisoras, quando tomadas em conjunto, oferecem melhores ferramentas conceituais e mais possibilidades analíticas para compreender o fenômeno da governança das doenças infecciosas. Nesse sentido, as abordagens propostas aqui servirão de pano de fundo para contextualizar as discussões sobre políticas internacionais de controle das doenças infecciosas nos próximos capítulos. Os elementos introduzidos na apresentação das abordagens tornarão a aparecer ao longo da problematização da agenda da saúde global, das formas de governança das doenças infecciosas e dos atores e mecanismos internacionais de controle das doenças infecciosas emergentes, objetos dos capítulos dois e três dessa dissertação. 


\section{COMO ANALISAR A GOVERNANÇA DAS DOENÇAS INFECCIOSAS EMERGENTES?}

Este capítulo argumenta que o modelo analítico da governança é adequado para analisar a forma como se articulam os atores, processos e políticas de controle, combate, prevenção e resposta às "doenças infecciosas emergentes" (DIEs) no sistema internacional. Para tanto, será realizada aqui uma breve revisão dos desenvolvimentos conceituais e teóricos sobre governança no estudo das Relações Internacionais. Entre as diversas acepções teóricas apresentadas, a de Oran Young (1999) será defendida como a mais adequada para os fins analíticos dessa pesquisa, pelos razões discutidas a diante.

Para complementar o modelo proposto por esse autor, esse capítulo introduz ainda a discussão sobre o conceito de governança no âmbito da saúde, dentre as quais serão destacadas as contribuições de David Fidler (2002, 2004, 2010). O principal argumento nessa sessão é o de que as acepções mais recentes do conceito de governança em saúde global acompanham as discussões sobre governança nas Relações Internacionais ao enfatizarem a ascensão de novos atores além do estado em âmbito internacional e também de novas formas de governar problemas coletivos. Assim como ocorre nas Relações Internacionais, o debate sobre a forma da governança internacional como distinta da global está no centro da discussão sobre o conceito de governança em saúde global. Essa diferença traduz-se na importância que tem outros atores, além do Estado e das organizações internacionais ${ }^{25}$, na gestão dos desafios dessa agenda.

Essa diferenciação das formas de governança - internacional ou global - é fundamental na problematização de como esses modelos analíticos devem ser empregados no estudo da governança das DIEs. Conforme será demonstrado ao longo desse capítulo, a agenda da saúde global é composta por uma coleção de diferentes temas, fazendo com que seja necessário analisar cada uma dessas "sub-agendas" individualmente para identificar qual forma de governança ela se submete. Para tanto, essa pesquisa se concentra em caracterizar a agenda das doenças infecciosas (DIs).

Apesar de haver um sistema de governança global das DIs, quando se trata especificamente das "doenças infecciosas emergentes", o que se observa é que essa matéria é objeto de governança internacional. Por isso, esse capítulo procura demonstrar que, em

\footnotetext{
25 A expressão "organizações internacionais" aqui se refere exclusivamente às instituições interestatais ou intergovernamentais.
} 
primeiro lugar, é possível destacar o tema das DIEs do grande escopo da agenda das DIs e trata-la como uma agenda específica passível de análise. Ademais, é a partir da delimitação desse objeto de estudo que se justifica a adoção do modelo analítico adotado para investigar a governança internacional das DIEs.

\subsection{Breve revisão dos desenvolvimentos conceituais e teóricos sobre governança}

$\mathrm{Na}$ literatura, o termo governança tem sido usado de maneira amplamente diversificada. Rhodes, no artigo "The New Governance: Governing without Government" (1996), identifica pelo menos seis usos diferentes para o termo. Quase uma década mais tarde, Philipp Pattberg (2006) amplia a lista para dez apropriações diferentes, ao discutir usos que se estendem desde aqueles relacionados ao Estado mínimo em face da gestão pública e privada responsabilidades coletivas, passando pela concepção de governança multinível encontrada na literatura acerca da União Européia, até o entendimento de governança como um tipo de ordem internacional no campo das relações internacionais, frequentemente na forma de regimes internacionais, que procuram resolver problemas transfronteiriços (PATTBERG, 2006, p.4).

O ecletismo nas definições conceituais e as diferentes apropriações do termo podem ser explicados pela variedade das raízes teóricas que os informam, assim como discute Stoker (1998, p.18): economia, relações internacionais, estudos organizacionais, estudos sobre o desenvolvimento, ciência política, administração pública, entre outros.

Não obstante, parece haver um consenso mínimo em toda essa literatura que permitiria conceber governança como o "desenvolvimento de estilos de governo em que as fronteiras entre e dentro ${ }^{26}$ dos setores públicos e privados tem se tornado turvas" (STOKER, 1998, p.17). Na mesma linha, Rhodes argumenta que a governança diz respeito a uma "mudança no significado de governo, em relação a um novo processo de governar; ou, uma mudança na condição das regras ordenadoras; ou, um novo método pelo qual a sociedade é governada" (RHODES, 1996, p.652-3).

Ambas essas definições aludem à dicotomia existente na literatura entre o conceito de governo e a noção de governança (ROSENAU, 1992; RHODES,1996, p.653, STOKER, 1998, p.17; ). Em muitos casos essa dicotomia é o ponto de partida para a investigação conceitual e analítica em torno do próprio termo governança. Especificamente no contexto da

\footnotetext{
${ }^{26}$ Tradução livre do original "between and within".
} 
ciência política, o termo é frequentemente usado em estreita relação com a noção de declínio no poderio e/ou proeminência da figura do Estado, em face da crescente importância adquirida por outros atores e a consequente interdependência entre os mesmos (PIERRE, 2000, p.2). Consequentemente, o conceito de governança é também evocado para destacar o profundo processo de transformação pelo qual o sistema de Estados westfaliano vem sendo submetido no bojo da globalização (ZACHER, 1992, p.59).

James Rosenau é o autor de uma das primeiras tentativas de sistematização teórica em torno do conceito de governança no campo da ciência política e relações internacionais. Argumentando que o aumento da interdependência complexa no sistema internacional leva ao aumento da demanda pela governança, o autor define essa como "sistemas de regras em todos os níveis da atividade humana - da família à organização internacional - em que a perseguição de objetivos por meio do exercício do controle tem repercussões transnacionais" (ROSENAU, 1995, p.13). O autor entende que "sistemas de regras", sejam esses formais ou informais, consistem em "esferas de autoridade", que são responsáveis por definir "o alcance da capacidade de gerar observância por parte daquelas pessoas a respeito das quais recaem seus objetivos" (ROSENAU, 2000, p.225).

Também na toada da dicotomia entre as noções de governo e governança, Rosenau argumenta que enquanto os sistemas de regras dos governos podem ser vistos como estruturas, os da governança são funções ou processos sociais que são desenvolvidos ou implementados numa variedade de maneiras, sem local ou tempo determinados, por diversos atores (ROSENAU, 2000, p.225). Nesse sentido, o autor concebe a existência de dois mundos na politica mundial: de um lado, há o tradicional sistema interestatal e seus governos nacionais. O segundo mundo seria formado por um sistema multicêntrico composto por uma variedade de coletividades que emergiu no curso das últimas décadas como uma fonte de autoridade que rivaliza, coopera e compete com o sistema interestatal. Por isso, para o autor, governança é inseparável da ideia de ordem no mundo globalizado (ROSENAU, 1992, p.3; SMOUTS, 1998, p.82), e, dessa forma se afasta da concepção de regimes internacionais, que são dedicados a uma área determinada das relações internacionais (ROSENAU, 1992, p.8).

Ironicamente, apesar da detalhada sistematização teórica em torno do conceito de governança proposto por Rosenau, essa abordagem se torna excessivamente abrangente e, logo, de difícil operacionalização em programas de pesquisa. Essas preocupações são levantadas por diversos autores, sendo que a mais significativa resposta talvez esteja no artigo "What is Global Governance?" de Lawrence Finkelstein (1995). Finkelstein argumenta que o alargamento conceitual realizado por Rosenau - nutrido pela sua visão da contundência da 
globalização como um processo fragmentador (ROSENAU, 2000, p.223) - para incluir novos atores, temáticas, esferas de atuação e processos, levou a elaboração de uma definição que pode ser associada a praticamente qualquer coisa (FINKELSTEIN, 1995, p.368).

Finkelstein (1995) reconhece a importância de um programa de pesquisa dedicado à governança pelo fato de que há a necessidade de compreender fenômenos de governo ("government-like events", no original) que ocorrem em âmbito internacional, sem a existência de um governo propriamente dito. Portanto, o autor propõe um entendimento da governança como, antes de mais nada, uma atividade. Por isso, argumentando que governança global é "fazer internacionalmente o que os governos fazem domesticamente", ele a define como sendo "o ato de governar, sem a soberania autoritária, as relações que transcendem as fronteiras nacionais" (FINKELSTEIN, 1995, p.369). Finkelstein também afirma que governança não é similar a regime internacional, pois esses se restringem às dimensões associadas à criação e implementação de regras e normativas internacionais, enquanto que a governança conta com uma série de outros mecanismos na orientação das políticas no sistema internacional.

Philipp Pattberg (2006) argumenta que governança compreende pelo menos três dimensões distintas. A primeira delas é a procedimental que põe ênfase nas atividades desempenhadas pelos atores e nas políticas empreendidas. A segunda, de cunho estrutural, diz respeito à arquitetura distinta na organização da governança, quando comparada com governos nacionais, por exemplo. A estrutura da governança global incluiria normas, regras, redes e constelações de atores interligados formal ou informalmente. Por fim, a terceira dimensão destaca seu caráter funcional enfatizando os seus resultados - tanto materiais quanto ideacionais - como equivalentes a outros arranjos políticos. A articulação dessas três dimensões pode ser percebida na definição proposta por Pattberg: governança global é "a soma de todas as instituições, processos e interações entre atores em todos os níveis do sistema sócio-político dirigidos, de maneira não hierárquica, a um problema global específico, destacando normas e regras de comportamento implícitas ou explícitas, induzindo pelo menos algum grau de repercussão transnacional" (PATTBERG, 2006, p.15).

A Comissão sobre Governança Global da ONU, realizada em 1995, trouxe ainda outra importante definição do fenômeno. Segundo o relatório intitulado "Our Global Neighborhood”, governança global é 
a soma das diversas maneiras com que indivíduos e instituições, sendo essas públicas ou privadas, gerenciam seus negócios comuns. É um processo contínuo durante o qual interesses conflitantes ou diversos podem ser acomodados e ações cooperativas podem ser tomadas. Inclui instituições formais e regimes com o poder de garantir a sua observância, bem como organizações informais sobre das quais pessoas e instituições acordaram ou perceberam ser de seu interesse. (COMMISSION ON GLOBAL GOVERNANCE, 1995, p.2-3).

A partir dessa definição, Marie-Claude Smouts defende uma abordagem para governança global a partir da perspectiva da análise de políticas públicas. A autora afirma que a erosão da autoridade do Estado, ao lado do incremento do processo de globalização, tem diminuído a barreira que separa as políticas públicas domésticas das políticas internacionais (SMOUTS, 1998, p.84). Para ela, a governança é responsável por reunir redes de diferentes tipos de atores, que não gozam das mesmas capacidades ou sequer da mesma legitimidade em torno de um tópico da agenda de interesse comum. Para responder a esses desafios, Smouts oferece uma visão processual de governança global, envolvendo a participação, negociação e coordenação entre diferentes atores em termos do desenvolvimento e implementação de projetos, parcerias e consensos (SMOUTS, 1998, p.86).

Gerry Stoker argumenta que a contribuição do estudo da governança para a teoria não está no nível da análise causal ou da sua potencial normatividade. $\mathrm{O}$ valor da perspectiva da governança está na capacidade de prover um modelo de compreensão dos "processos de governar" (STOKER, 1998, p.18). Esse modelo traria tanto um vocabulário quanto uma moldura de referência com os quais a realidade poderia ser analisada. Portanto, o autor discute cinco proposições desse para a formulação desse modelo: governança se refere a um conjunto de instituições que fazem parte do governo, mas que também são independentes a esse; responde a problemas socioeconômicos de maneira transfronteiriça; identifica as relações de poder existentes entre os problemas coletivos e as instituições envolvidas; é constituída de redes de atores autônomos "auto-governantes"; e, por fim, reconhece as capacidades de realização e atividade como não sendo propriedades exclusivas dos governos.

\subsubsection{Governança na perspectiva de Oran Young}

O modelo analítico a ser empregado nessa pesquisa é informado pela abordagem de governança proposta por Oran Young (1999). Em "Governance in World Affairs", o autor discute como o aprofundamento do processo de globalização com o fim da Guerra Fria e o consequente crescimento da interdependência entre os membros da sociedade internacional 
levaram ao aumento da demanda por governança. Young identifica três respostas para esse problema: a primeira delas diz respeito a certa frustração e pessimismo quanto à capacidade de lidar com problemas globais que alguns observadores tem reagido.

A segunda resposta aponta para a necessidade de reformar as instituições já existentes - em especial o sistema ONU - como forma de suprimento da demanda por governança. Segundo o autor, uma contribuição particular para essa resposta é sintetizada no relatório da Comissão sobre Governança Global, "Our Global Neighborhood” (1995).

A terceira resposta, à qual Young se vincula, preocupa-se em enfatizar a diferença entre governo e governança dirigindo a atenção para a diversidade de práticas e processos sociais que emergem para solucionar problemas globais. Essa abordagem de governança, diferentemente do que é proposto pela perspectiva reformista, delineia o papel dos "issuespecific arrangements" 27 que apresentem capacidade mandatória ou não, que possam ou não estar vinculadas ao mandato da ONU ou de alguma de suas agencias, e que frequentemente dedicam funções relevantes a atores não-estatais.

Nesse sentido, Young vincula sua proposta de governança à própria concepção de regimes internacionais. Existem pelo menos duas definições clássicas para esse conceito. Robert Keohane e Joseph Nye (1977) definem regimes como "conjunto de disposições governantes que incluem redes de normas, princípios e procedimentos que regularizam o comportamento e seus efeitos". Essa definição é compatível com a de Stephen Krasner (1983) no artigo "Structural causes and regime consequences", em que regimes são entendidos como o "conjunto de princípios, normas, regras e processos decisórios, implícitos ou explícitos, em torno dos quais as expectativas dos atores convergem em uma determinada área das relações internacionais".

É interessante notar que Young reedita esse conceito para aplica-lo a sua abordagem de governança. Para esse autor, regimes internacionais são estruturas sociais que podem ser definidos como "conjuntos de regras, processos decisórios e/ou programas que dão origem a práticas sociais, designam papeis aos participantes dessas atividades e governam suas interações" (YOUNG, 1980, p.332). Destaca-se dessa conceituação a sua dimensão sociológica que confere importância à noção constitutiva imbuída na dinâmica dos regimes internacionais em que se reconhece a capacidade de construção dos papeis sociais dos atores envolvidos, em termos de seus próprios interesses e identidades. É também por esse motivo

27 “arranjos para problemas específicos”, em tradução livre. 
que o autor argumenta que os regimes internacionais diferem quanto ao grau de formalidade legal de suas normas e princípios.

Três características gerais dos regimes internacionais são discutidas por Young a partir dessa conceituação particular que ajudam a compreender a escolha dessa abordagem como o modelo analítico orientador dessa pesquisa. Em primeiro lugar, como discutido anteriormente, os regimes internacionais são respostas para problemas específicos, sendo que eles não procuram prover mecanismos de ordem pública de maneira sistemática ou generalizante, mas sim se dedicam a responder pragmaticamente problemas bem definidos. Segundo, os regimes incorporam uma diversidade de atores não-Estatais que se tornaram importantes e ganharam proeminência nas últimas décadas, apesar de ainda reconhecer os Estados como centros de poder e autoridade. Terceiro, se tomados em conjunto, os regimes internacionais formam um sistema de ordem pública mais horizontal do que vertical ou hierarquizado. Isso resulta num complexo padrão de autoridades descentralizadas (YOUNG, 1999).

Ademais, a concepção de governança proposta por esse autor está imbuída numa noção mais ampla de sociedade internacional. Isso ressalta o papel da construção coletiva das normas e aponta para a organização social do comportamento dos Estados e de outros atores no sistema internacional. Por esse motivo, a ideia que Young faz de governança dialoga com as abordagens revisoras de segurança internacional, na medida em que essas criticam a percepção do sistema internacional como um espaço essencialmente anárquico, conflituoso e dominado por forças de cunho bélico.

\subsection{Governança em saúde global}

O desenvolvimento do conceito de governança em saúde global nos círculos acadêmicos e institucionais da saúde pública dialoga com a evolução da discussão sobre globalização e governança global no campo das relações internacionais (RICCI, 2009). Isso significa dizer que, por mais que haja pouco diálogo entre essas duas comunidades acadêmicas, os temas e as agendas de pesquisa abordadas no debate teórico sobre governança em saúde global são semelhantes aos dos estudos sobre governança nas relações internacionais. Em ambos os casos, há o interesse quanto aos impactos da globalização na política internacional, o aumento da importância de novos atores transacionais, e das transformações da figura e do papel do Estado nesse contexto. 
Em busca de uma conceituação precisa, vale esclarecer que a expressão "governança em saúde global" tem sido utilizada pela literatura especializada com pelo menos três sentidos diferentes, dando origem a três variações ontológicas para o conceito (LEE; KAMRADTSCOTT, 2014). A primeira forma de apropriação do termo encontrada na literatura diz respeito à relação entre governança global e saúde, enfatizando como instituições internacionais que não pertencem a esse setor têm influenciado os determinantes sociais da saúde $^{28}$ - e, consequentemente, as políticas de saúde global e seus resultados. Evidência desse fenômeno pode ser observada especialmente em relação à atuação de organismos multilaterais de comércio (OMC, OCDE, etc.) e de instituições financeiras (Banco Mundial, Fundo Monetário Internacional, etc.) que impacta a agenda da saúde ${ }^{29}$.

A segunda forma em que governança em saúde global tem sido utilizada pela literatura especializada é no sentido enfatizar a necessidade de governança para saúde global. Esse uso procura destacar o caráter normativo na gestão dos problemas da saúde, preocupando-se em discutir os fundamentos éticos e a importância dos valores no desenvolvimento das políticas de saúde global (LEE; KAMRADT-SCOTT, 2014; RUGER, 2012; STEWARD et al., 2011). Dessa forma, o compromisso com a solidariedade global e com as responsabilidades compartilhadas são as bases normativas que orientam esse entendimento de governança (OTTERSEN et al., 2014). Isso faz com que seus temas centrais sejam as questões distributivas relacionadas às desigualdades das condições de saúde (BROWN, 2012), direitos humanos (GABLE, 2007; MEIER; ONZIVU, 2014), acesso aos serviços primários de saúde (DICKERSON, 2012), entre outros.

A terceira variação ontológica do uso da expressão governança em saúde global - que será adotada nessa pesquisa - procura destacar a atuação de instituições, regimes e processos políticos que governam os temas da agenda da saúde no mundo globalizado (LEE; KAMRADT-SCOTT, 2014, sp). Nesse sentido, ela é entendida primordialmente como uma agenda da política internacional, sendo a mais substancial e mais difundida na literatura especializada. Diferentemente do uso discutido acima, ela evita proposições normativas

\footnotetext{
${ }^{28}$ Segundo a OMS, os determinantes sociais da saúde são "condições em que as pessoas nascem, crescem, vivem, trabalham e envelhecem, incluindo o sistema de saúde" que, por sua vez, são definidos por escolhas políticas a respeito da "distribuição de dinheiro, poder e recursos em nível local, nacional e globais" (WORLD HEALTH ORGANIZATION, 2014g).

${ }^{29}$ Diversos autores estudam o impacto de instituições financeiras internacionais na saúde global. Ruckert e Labonté (2013) e Rowden (2009) analisam a relação entre a crise financeira e a saúde global abordando a atuação do Fundo Monetário Internacional em ambas as esferas. Yang e Mcdaniel (2012) avaliam os impactos das empresas privadas multinacionais no setor da saúde pública. Ruger (2005) discute as mudanças na atuação do Banco Mundial em saúde global ao longo do século XX.
} 
enfatizando a dimensão empírica da gestão dos desafios da saúde no mundo, analisando como Estados, organismos internacionais, atores transnacionais e do terceiro setor interagem na conformação de condições e regras sobre a saúde no mundo.

Dentro dessa perspectiva, estão os contidos três elementos tidos como essenciais da governança em saúde global (DODGSON et al., 2002, p.17). Esses três elementos explicam como esse conceito de governança em saúde global é compatível com a definição de governança global discutida pela literatura de relações internacionais. O primeiro deles é a "deterritorialização" dos fenômenos da saúde no mundo. A intensificação dos processos da globalização faz com que os desafios no campo da saúde não possam ser contidos nas fronteiras nacionais, e, por isso é fundamental compreendê-los como problemas comuns que demandam esforços coletivos (KELLEY, 2011).

Advém desse fator o segundo elemento que é a intersetorialidade dessa agenda (NG; RUGER, 2011). Se a saúde das populações é resultado da interação complexa entre os determinantes sociais da saúde, que, por sua vez, são resultados de políticas e processos de diversos setores além da própria saúde pública, faz sentido reconhecer que a governança em saúde global é intersetorial e opera na confluência de diferentes agendas (LABONTÉ; SCHRECKER, 2007). É inegável o impacto que os desafios colocados pela mudança climática, por exemplo, têm sobre a saúde em diversos países. As políticas de propriedade intelectual e de produção e comércio de medicamentos também afetam direta ou indiretamente a disponibilidade e acessibilidade aos recursos necessários para o provimento da maioria dos serviços de saúde pública.

Por fim, o terceiro elemento dessa abordagem é a incorporação de novos atores, além dos Estados e dos organismos internacionais, também envolvidos com os processos da gestão internacional dessas políticas, debate que também ocorre na discussão sobre globalização e governança no campo das relações internacionais (RICCI, 2009). A avaliação da relevância desses novos atores na determinação das agendas políticas e na elaboração e implementação de regimes internacionais, em um sistema internacional onde o Estado-nação ainda é uma figura política proeminente, também é tema de debate nesse campo, conforme será analisado mais adiante. De qualquer forma, ressalta-se aqui que esse conceito de governança em saúde global leva em consideração a diversificação dos atores que influenciam em maior ou menor grau, formal ou informalmente, o desenvolvimento de políticas internacionais para a saúde.

Segundo Harman (2012), o que caracteriza a governança em saúde global são os acordos transfronteiriços e as iniciativas entre os Estados e/ou atores não-Estatais para o controle da saúde pública, das doenças infecciosas e para a proteção das pessoas dos riscos à 
saúde. Pang et al. (2010, p.1181) argumentam que a governança em saúde global é formada pelas "instituições formais ou informais, normas e processos que governam ou que diretamente influenciam as políticas na área da saúde e seus resultados em todo o mundo.” Contudo, a definição proposta por David Fidler (2010), apesar de não se distanciar das demais apresentadas, ainda é a que captura em maior detalhamento e com maior precisão o fenômeno, e por isso é a que orienta essa pesquisa. Segundo esse autor, a governança em saúde global "refere-se ao uso de instituições formais e informais, regras e processos pelos Estados, organizações intergovernamentais e atores não-Estatais para lidar com os desafios na área da saúde que requerem ações coletivas transfronteiriças" (FIDLER, 2010, p.3).

Para compreender com propriedade os desdobramentos analíticos dessa conceituação de governança em saúde global, é necessário discutir a diferenciação feita por Fidler acerca dos fenômenos da governança internacional e global. Conforme o próprio autor argumenta, o conceito por ele proposto de governança em saúde global parte de premissa de que há uma distinção entre governança global e internacional ${ }^{30}$. Essa diferenciação é necessária, pois diversos autores engajados nessa discussão entendem que há um período de transição, iniciado a partir da última década século $\mathrm{XX}$, em que a governança internacional da saúde ${ }^{31}$ começou a dar espaço para a emergência de um sistema de governança em saúde global (DODGSON et al., 2002; NG; RUGER, 2011).

Segundo essa literatura, a intensificação da globalização é o fator motriz nesse processo. Brundtland (2003, p.417) afirma que a globalização fez com que não hajam mais "santuários de saúde" no mundo, reconhecendo o risco global ao qual todos os países e populações estão submetidos em matéria de saúde. Loughlin e Berridge (2002, p.5), argumentam que a globalização produz consequências e coloca desafios para a saúde no mundo que as formas existentes de governança nessa agenda - ou seja, os sistemas de governança internacional - "não conseguem resolver eficientemente”. No mesmo sentido, Lee e Dodgson (2000) apontam para o fato de que a globalização "introduziu ou intensificou os riscos [em saúde] para além das fronteiras nacionais", principalmente no que diz respeito à emergência de novas doenças, bem como o retorno daquelas já erradicadas, tema que ocupa grande parte da agenda da saúde pública, na esfera nacional e internacional desde o início da década de 1990.

\footnotetext{
${ }^{30}$ Para Zacher (2007, p.15), a governança internacional em saúde é sinônimo de "regime internacional da saúde". ${ }^{31}$ Nessa pesquisa, a expressão "governança internacional em saúde" é adotada como sinônimo de "governança em saúde internacional". O mesmo serve para os conceitos de "governança global da saúde" e "governança em saúde global".
} 
Para Fidler (2002, p.7), as definições de governança internacional e global diferem em pelo menos três critérios distintos: (1) quanto aos atores envolvidos na dinâmica da governança, (2) quanto à fonte das regras, e (3) quanto à sua aplicabilidade.

No âmbito da governança internacional, são reconhecidos como atores os Estados e as organizações internacionais. O mesmo é defendido por $\mathrm{Ng}$ e Ruger (2011), que afirmam que a governança internacional da saúde até os anos 1990 é tarefa compartilhada pelos Estados e organizações internacionais. A fonte das regras que orientam o comportamento desses atores nessa perspectiva está contida nos tratados, no direito internacional consuetudinário e nos princípios gerais do Direito, sendo que essas normativas todas são aplicáveis nas relações entre os Estados, seja direta ou indiretamente por meio das organizações internacionais.

Para a sua definição da governança global, todas essas três dimensões são alargadas para incluir novas unidades de análise. Tanto Estados, organizações internacionais, corporações multinacionais, organizações não-governamentais e indivíduos são reconhecidos e considerados participantes da dinâmica da governança. Os papeis desempenhados pelos Estados, agencias das Nações Unidas, organizações não-governamentais, parcerias público privadas, organizações transacionais e da sociedade civil nesse contexto, apesar de influenciarem e diversas vezes determinarem os resultados das processos, não são bemdefinidas e nem necessariamente coordenadas entre si. Novos atores trazem para o ambiente político mais recursos, outras formas de organização, diversificam os interesses em jogo e redistribuem responsabilidades. Isso que faz com que a governança global na área da saúde tenha uma estrutura muito menos clara e mais complexa do que a internacional (NG; RUGER, 2011, p.2). Por isso, para Fidler (2002), além das fontes de regras formais, para a governança global também são importantes os mecanismos de "soft law" e as normas não-mandatórias 32 sendo que o escopo de aplicação e efeito de todas elas está nas relações entre os Estados e as atividades e comportamentos dos atores não-estatais e indivíduos.

Em suma, a distinção feita por David Fidler entre governança internacional e global útil especialmente na análise da agenda da saúde - percebe-se na inclusão nessa dinâmica de atores não-estatais e dos reflexos disso na criação e gestão das normativas internacionais. Nesse sentido, essa abordagem dialoga com proposições de outros autores que também investigam o fenômeno da governança em saúde global (LEE; DOGSON, 2000; DOGSON et al., 2002) na medida em que todos eles discutem como, ao interferirem na gestão dos “problemas globais" na área da saúde, a atuação desses novos atores leva a transformações na

\footnotetext{
32 "non-binding norms", no original.
} 
elaboração e aplicação das regras e também do papel dos Estados. Esse argumento é elaborado no esquema apresentado abaixo, que descreve a dinâmica normativa da governança global:

Figura 3 - Esquema da dinâmica da governança em saúde global.

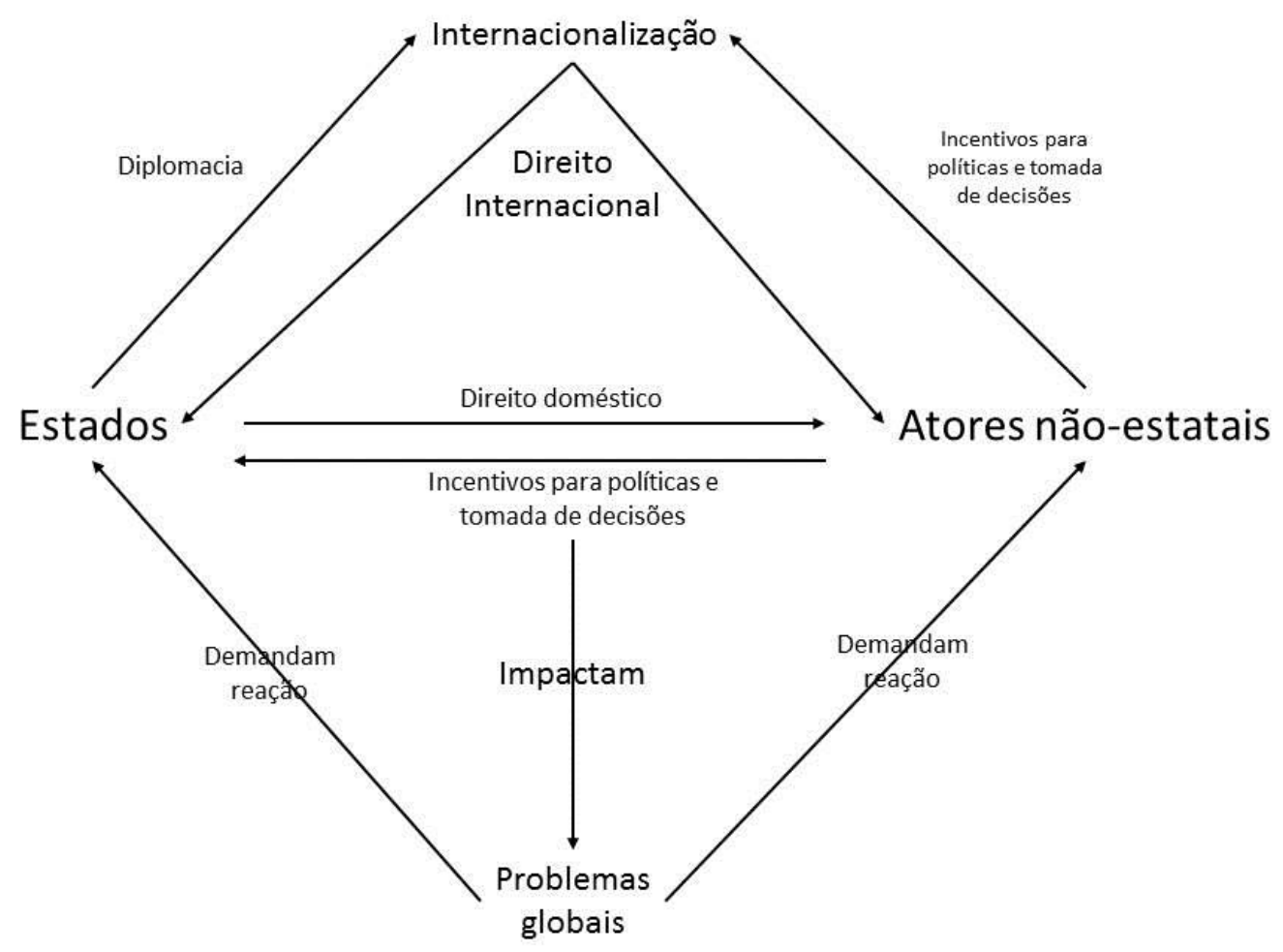

Fonte: Tradução e adaptação livres a partir da figura apresentada em FIDLER, David. Global Health Governance: Overview of the Role of International Law in Protecting and Promoting Global Public Health. World Health Organization, 2002. Disponível em: <http://cgch.lshtm.ac.uk/ghg3.pdf $>$ Acesso em: 15 de novembro de 2013.

A dinâmica apresentada no esquema acima inicia-se quando um problema global pressiona tanto Estados quanto atores não-estatais a reagirem. O autor define problemas globais como sendo aqueles causados, em sua totalidade ou em parte, por atores ou eventos situados além do controle dos Estados (FIDLER, 2002, p.8). Quando os atores pressionados percebem que o problema não pode ser resolvido efetivamente por meio da política e do direito somente na esfera doméstica, o problema é internacionalizado. Enquanto os Estados engajam na diplomacia (que pode se dar por meio de um organismo internacional), os atores não-estatais procuram influenciar a agenda de discussão e seus desdobramentos.

O resultado comum desse jogo de negociação é dado na forma de regras do direito internacional, cujos efeitos recaem sobre os Estados e também sobre os atores não-estatais. Para implementar as normativas internacionais, frequentemente os Estados tem que incorporá- 
las em seu sistema de direito doméstico, processo o qual também sofre a influência da ação dos atores não-estatais. Por fim, a combinação das normativas internacionais e nacionais é que tem impacto no problema global.

\subsection{Problematizando a aplicação dos modelos analíticos de governança na agenda de doenças infecciosas emergentes}

Para compreender a maneira adequada de analisar a governança das doenças infecciosas emergentes, essa pesquisa procura, em primeiro lugar, problematizar a aplicação dos conceitos e teorias de governança discutidos acima ao analisar a agenda de saúde global à qual o tópico das DIEs se subscreve. Conforme será defendido adiante, a existência de diversos temas distintos que a "agenda de saúde global" envolve impossibilita a caracterização dessa como objeto de governança internacional ou global, exclusivamente. O que se observa é que temas diferentes dessa agenda podem ser objeto de governança internacional ou global, independentemente um do outro. Para solucionar esse problema, essa pesquisa defende a necessidade de delimitar o objeto estudado, ou seja, o estudo das formas de governança nessa agenda deve abordar os temas específicos - doenças infecciosas, tecnologias em saúde, propriedade intelectual, formação de recursos humanos, etc separadamente.

É nesse sentido que a seguir será problematizada a aplicação do modelo analítico de governança de David Fidler (2002) para o estudo dos temas de saúde global. No sentido de operacionalizar essa compreensão da agenda de saúde global, será caracterizada a agenda de controle das doenças infecciosas para demonstrar que essa é objeto de governança global adotando a categorização de Fidler (2002) discutida anteriormente. Posteriormente, isso será abordado com a análise de como se dá a governança de uma subcategoria das DIs, as doenças infecciosas emergentes, que, conforme essa pesquisa defende, deve ser entendida como governança internacional. Acredita-se que é somente a partir dessa problematização e da especificação do objeto da pesquisa que possa ser justificado a adoção dos modelos teóricos de Young (1999) e David Fidler (2002) para o estudo da governança internacional das doenças infecciosas emergentes, esforço a ser empreendido no terceiro capítulo dessa dissertação. 


\subsubsection{Saúde global}

Na literatura, encontram-se vários conceitos de saúde global. Koplan et al. (1993) argumentam que a adoção consensual de um conceito de saúde global é imprescindível para o estabelecimento de uma agenda compartilhada e objetivos definidos, tanto no campo acadêmico como na prática institucional, por mais que haja dissenso quanto ao seu significado. Esses autores propõem o entendimento de saúde global como "uma área de estudo, pesquisa e prática que prioriza a melhoria na saúde e o alcance da equidade para todas as pessoas no globo". Também numa perspectiva normativa, Macfarlane et al. (2008) descrevem o campo enquanto "a melhoria global da saúde em termos de redução de disparidades e proteção contra ameaças globais que ultrapassam as fronteiras nacionais".

Adota-se, aqui, a compreensão de saúde global trazida por Kickbusch (2006) que apresenta uma definição objetiva do termo alinhada ao nível de análise do sistema internacional: "aqueles temas de saúde que transcendem fronteiras nacionais e governos e rogam por ações das forças globais que determinam a saúde das pessoas”.

Definida dessa maneira, a agenda da saúde global é composta por uma coleção de diferentes temas ${ }^{33}$. Doenças infecciosas, sistemas de saúde, propriedade intelectual e desenvolvimento tecnológico de recursos e insumos, saúde ambiental, formação e distribuição de recursos humanos e doenças não-comunicáveis ${ }^{34}$ são alguns dos assuntos que estão sob o chapéu da saúde global, disputando a atenção dos atores e competindo por espaço na lista de prioridades dessa agenda. Tomados isoladamente, cada um desses assuntos tem características e desafios diferentes. Isso faz com que os seus processos de negociação, os recursos normativos e os atores interessados neles sejam também distintos.

Cada uma dessas "sub-agendas" têm protocolos e dinâmicas próprias e, em alguns casos, foros de negociação e ambientes institucionais específicos. Por exemplo, a discussão acerca da destruição dos estoques remanescentes do vírus da varíola é um assunto de biossegurança com alta sensibilidade política discutido na Assembleia Mundial da Saúde com a participação de diplomatas, cientistas, militares e técnicos de saúde (TUCKER, 2011, p.63).

Já a propriedade intelectual e o desenvolvimento tecnológico de recursos e insumos para a saúde é um assunto que tem diversas implicações bioéticas e distributivas sobre as condições de saúde nos países e cujo tratamento internacional vai além do escopo de atuação

\footnotetext{
${ }^{33}$ A agenda de discussão das últimas reuniões da Assembleia Mundial da Saúde evidencia claramente essa variedade temática. Esses dados estão disponíveis integralmente de 1998 a 2013 por meio do link: http://apps.who.int/gb/or/

${ }^{34}$ Também conhecidas como "doenças crônicas".
} 
da OMS, fazendo com que outros organismos internacionais (Organização Mundial do Comércio, por exemplo) e empresas privadas (laboratórios farmacêuticos, produtores de equipamentos médicos, etc.) participem ativamente dessas negociatas.

Além disso, os tópicos da agenda de saúde global dizem respeito à mitigação de problemas específicos que comprometem a saúde das populações. Cada um desses desafios demanda estratégias de intervenção, programas e políticas de resposta muitas vezes especializadas, evidenciando ainda mais a complexidade da agenda de saúde global. Erradicação da poliomielite, desenvolvimento de novas drogas antirretrovirais, investimento em saneamento básico, atenção primária à saúde, redução da mortalidade infantil, redução do tabagismo e implantação de protocolos de comunicação em emergências internacionais são apenas alguns exemplos de problemas de saúde pública abordados no âmbito da saúde global que demonstram a variedade disciplinar e política engendrada nesse campo.

Esse entendimento da agenda de saúde global dá origem a uma acepção teórica acerca da governança nessa área. David Fidler (2010) argumenta que a saúde global é governada por um "complexo de regimes internacionais", devido à amplitude e diversidade dos temas abordados e sua relevância para diversas áreas da política internacional. Dessa forma, a governança da saúde global é composta de “diversos regimes sobrepostos pelos quais múltiplos atores respondem problemas específicos por meio de diferentes processos, aplicando princípios diversos" (FIDLER, 2010, p.9).

Decorre disso que a agenda da saúde global não é uniforme. Muito pelo contrário, essa esfera da política internacional é um emaranhado complexo de áreas de trabalho que compartilham entre si pelo menos uma propriedade fundamental: o fato de todos esses temas estarem diretamente relacionados com a saúde das populações a nível internacional. Essa proposição está de acordo com o conceito de saúde global proposta por Kickbush (2006) citada acima.

Para além dessa condição fundamental, a "saúde global", conforme entendida aqui, é um apanhado de diferentes agendas que diferem largamente entre si quanto ao grau de institucionalização política, de densidade dos regimes internacionais (caso existam), de adesão e interesse por parte de países e outros atores, de gravidade e urgência do tema e de disponibilidade financeira.

Por isso, caracterizar a agenda da saúde global dessa maneira implica em reconhecer que não faz sentido rotular a saúde global como objeto de governança global ou internacional. Se a saúde global é mais bem compreendida como uma coleção de "sub-agendas" distintas entre si, o estudo da governança nesse campo deve considerar esses assuntos separadamente. 


\subsubsection{Governança das doenças infecciosas}

Segundo a OMS, doenças infecciosas "são aquelas causadas por microrganismos patogênicos, tais como bactérias, vírus, parasitas ou fungos. Essas doenças podem ser transmitidas, direta ou indiretamente, de uma pessoa para outra." ${ }^{, 35} \mathrm{O}$ controle das doenças infecciosas é uma agenda estabelecida internacionalmente que conta com foros institucionalizados e burocracias distintas das demais áreas. As doenças infecciosas figuram praticamente todos os anos como uma pauta específica da Assembleia Mundial da Saúde. No âmbito nacional, diversos Ministérios da Saúde de diferentes países tem unidades burocráticas especializadas na condução das políticas públicas nesse domínio.

A propagação internacional das doenças infecciosas é uma agenda particular da saúde global na medida em que ela ocupa um espaço tradicional nesse campo. Uma rápida revisão sobre a história da saúde pública internacional deixa claro que foi esse tema o primeiro a ser matéria de interesse entre os países, quando esses ainda no século XIX se reuniram nas primeiras conferências sanitárias internacionais (LOUGHLIN; BERRIDGE, 2002; FIDLER, 2003a). Nessas ocasiões, o entendimento compartilhado de que os riscos para a saúde era praticamente restritos às infecções orientou o desenvolvimento das primeiras políticas comuns de higiene e quarentena para tráfego de pessoas e bens (DODGSON et al., 2002). Isso demonstra que muito antes de se preocuparem com a acessibilidade aos serviços de saúde, direitos humanos, prevenção às doenças não-comunicáveis e outros temas contemporâneos, os Estados dedicaram esforços para conter a propagação transfronteiriças das doenças infecciosas.

Outros fatores ligados à natureza das doenças infecciosas fazem com que essas constituam uma agenda específica da saúde global. Fauci e Morens (2012, p.455) listam algumas características que separam das doenças infecciosas dos demais problemas de saúde. Dentre essas características destacam-se a transmissibilidade, o potencial para impacto global, a possibilidade de identificação do agente causador da doença e a possibilidade de erradicação. Esses fatores diferenciam as doenças infecciosas dos demais riscos à saúde das populações e por isso demandam respostas especializadas na sua prevenção e controle.

Para descrever a agenda das doenças infecciosas e de que maneira ela é governada essa sessão será informada pela descrição feita por Fidler (2002) para diferenciar a governança internacional da global, já discutidos anteriormente. A partir desse quadro-

\footnotetext{
${ }^{35}$ Tradução livre da definição disponível em: <http://www.who.int/topics/infectious_diseases/en/>
} 
analítico, acredita-se que observando a origem e aplicabilidade das normas e a variedade e atuação dos atores engajados na agenda de controle das doenças infecciosas, seja possível definir se essa é atualmente objeto de governança global ou internacional. Por isso, tendo em mente esse objetivo, a seguir será discutida a atuação dos Estados, organismos internacionais e organizações da sociedade civil e empresas privadas transnacionais num esforço de caracterizar a governança global das doenças infecciosas.

Devido a padrões epidemiológicos diferenciados, qualidade dos sistemas de saúde e condições sociais e geográficas, Estados tem necessidades e interesses distintos no tocante ao controle das doenças infecciosas. Enquanto doenças como HIV/AIDS, poliomielite e influenza constituem um risco para a saúde pública global, outras doenças como malária, dengue e outras doenças tropicais são endêmicas apenas em determinadas regiões do planeta. Isso faz com que esses países busquem influenciar a elaboração da agenda de doenças infecciosas muitas vezes com motivações e objetivos concorrentes.

A forma como cada Estado organiza seu sistema de saúde é uma variável fundamental para compreender seu impacto nas políticas de controle das doenças infecciosas. Além disso, diversos governos financiam órgãos de pesquisa que auxiliam na elaboração de políticas de prevenção, controle e resposta às epidemias, como é o caso do Centers for Disease Control and Prevention e no National Institute of Health, nos Estados Unidos, o Public Health Agency do Canadá, e a Fundação Oswaldo Cruz, no Brasil. Essas instituições, juntamente com associações acadêmicas e outros entes da comunidade epistêmica, informam tecnicamente governos, organismos internacionais e outras instituições sobre matérias de saúde pública necessária para o controle das doenças infecciosas, tais como, epidemiologia, microbiologia, imunologia, entre outras.

A cooperação internacional também é uma das vias pelas quais Estados se envolvem na agenda de controle das doenças infecciosas. Isso parece ser significativo especialmente no caso da ajuda internacional prestada pelos países desenvolvidos. O Fundo Global para Combate à AIDS, Tuberculose e Malária, em 2013, angariou 12 bilhões de dólares, em que 95\% é proveniente de governos doadores - sendo que os 10 maiores contribuidores são todos países desenvolvidos (THE GLOBAL FUND, 2014). Além disso, os EUA, isoladamente, contribuem com 9 bilhões de dólares para a cooperação em saúde global, aproximadamente 6 bilhões são rubricas endereçadas aos programas na área de doenças infecciosas especificamente para HIV/AIDS, tuberculose e malária - sendo que praticamente todo esse montante apoia projetos na África subsaariana e no sul asiático. 
As abordagens de como as doenças infecciosas são entendidas como assuntos de segurança internacional discutidas no capítulo anterior também servem para demonstrar os vários motivos que levam países a se engajarem nas políticas internacionais contra a propagação de doenças infecciosas.

São vários os organismos internacionais que participam da governança das doenças infecciosas. A Organização Mundial da Saúde tem um histórico de dominar a agenda da saúde (DAVIES, 2008) e por isso também é a principal instituição internacional envolvida no controle internacional das doenças infecciosas. Esse papel desempenhado pela Organização nessa agenda é desdobramento do seu objetivo geral delineado na Constituição da OMS: "a consecução por todos os povos dos mais altos padrões de saúde" (WORLD HEALTH ORGANIZATION, 1946, p. 1). Além disso, dentre os diversos objetivos específicos, a Constituição também estipula que a instituição deverá trabalhar para erradicar doenças epidêmicas e endêmicas.

Contudo, as atividades da OMS vão muito além da tradicional ajuda humanitária em prol da melhoria da saúde das populações: envolvida na governança das doenças infecciosas, a Organização é o principal provedor de bens-públicos de saúde e atua politicamente no sentido de influenciar políticas domésticas e internacionais.

Está sob jurisprudência da OMS o "Regulamento Sanitário Internacional (2005)" (RSI), que é o principal mecanismo normativo do regime de doenças infecciosas (WORLD HEALTH ORGANIZATION, 2014e). Essa é um acordo de caráter vinculante que estabelece "um novo quadro para a coordenação da gestão de eventos que podem constituir uma emergência de saúde pública de preocupação internacional, aprimorando a capacidade de todos os países de detectar, avaliar, notificar e responder às ameaças à saúde pública" (WORLD HEALTH ORGANIZATION, 2014e, sp.).

A história do RSI remonta à epidemia de cólera na Europa no século XIX, quando foi realizada a primeira conferencia sanitária internacional, em 1851 (BRADY, 2007). Desde então, a peça foi submetida a diversas revisões, sendo que a versão atual foi aprovada na Assembleia Mundial de Saúde da OMS em 2005. O objetivo do RSI (2006, p.18) é "prevenir, proteger, controlar e dar uma resposta de saúde pública conta a propagação internacional das doenças, de maneiras proporcionais e restritas aos riscos para a saúde pública, e que evitem interferências desnecessárias com o trafego pessoas e comércio internacionais". Nesse sentido, o RSI caracteriza o controle internacional das doenças infecciosas como uma questão de segurança global da saúde pública (WORLD HEALTH ORGANIZATION, 2009a). 
Para além do escopo do RSI, a OMS contribui para a difusão de informação técnicocientífica sobre o assunto com a publicação de manuais, diretrizes e recomendações para o controle epidemiológico, diagnóstico e tratamento de doenças específicas. Exemplos dessas publicações são "Dengue guidelines for diagnosis, treatment, prevention and control" (WORLD HEALTH ORGANIZATION, 2009b) e "Cholera outbreak: assessing the outbreak response and improving preparedness" (WORLD HEALTH ORGANIZATION, 2004b). Esses documentos orientam práticas em saúde pública e fixam padrões reconhecidos internacionalmente que orientam a elaboração de políticas públicas pelos Estados-parte. Ademais, a Organização mantem banco de dados estatísticos do impacto internacional das doenças infecciosas ${ }^{36}$. Essas estatísticas subsidiam a redação de relatórios sobre a situação de epidemias ou do avanço no controle de doenças, como é o caso do "Global tuberculosis report 2013” (WORLD HEALTH ORGANIZATION, 2013b).

O caráter político da atuação dessa instituição nessa agenda também é percebido por meio de uma variedade de programas que investem no combate internacional às doenças infecciosas. Esses programas adotam diferentes estratégias para lidar internacionalmente com o problema. Por exemplo, ao reconhecer que a imunização da população contra a gripe sazonal é uma "intervenção essencial de saúde pública para o combate às epidemias e pandemias da doença” (WORLD HEALTH ORGANIZATION, 2006, p. V), a OMS lançou em 2006 o "Global pandemic influenza action plan to increase vaccine supply". Esse programa objetiva aumentar a disponibilidade e o uso da vacina contra a gripe sazonal, investindo no aumento da sua produção, pesquisa e desenvolvimento. Diferentemente, o “Global Task Force on Cholera Control” procura reduzir a mortalidade associada à cólera e também os seus impactos socioeconômicos na população. Para esse intuito, o programa investe em vigilância epidemiógica a fim de identificar grupos vulneráveis, capacitando os Estados com altos indicies de incidência da doença na implementação de saneamento básico e em políticas de imunização (WORLD HEALTH ORGANIZATION, 2014f). Esses são apenas alguns exemplos de programas dedicados a doenças específicas que demonstram o envolvimento ativo da OMS na governança das doenças infecciosas: além do combate à gripe sazonal e à cólera, a instituição também tem importantes projetos para a malária, HIV/AIDS, tuberculose, dengue, entre outras.

Apesar de tradicionalmente se ocupar desse tema e dominar a agenda da saúde global, a OMS não é o único organismo internacional envolvido na governança das doenças

\footnotetext{
${ }^{36}$ Esse banco de dados estatístico pode ser consultado online por meio do link: 〈www.who.int/research/en $>$
} 
infecciosas. Em grande parte isso se deve a multidisciplinariedade e intersetorialidade desse tema: o controle das doenças infecciosas enquanto um objetivo de saúde global depende também dos avanços em outras agendas políticas (PLOTKIN; KIMBALL, 1997; NG; RUGER, 2011).

A literatura especializada demonstra que fatores ecológicos são importantes variáveis na emergência de novas doenças (WOOLHOUSE; GAUNT, 2007; GUERNIER et al., 2004). Dentre esses fatores, destaca-se a interação entre a atividade humana e saúde animal. Mais de $60 \%$ dos patógenos que causam doenças infecciosas em seres humanos tem origem animal dentre elas, SARS, HIV/AIDS, raiva, entre outras (VALLAT, 2013, p.2). Isso explica a importância do envolvimento de organismos como a Organização Mundial de Saúde Animal (OIE) e a Organização das Nações Unidas para a Alimentação e Agricultura (FAO). Essas duas instituições, conjuntamente com a OMS, UNICEF, Banco Mundial e o UN System Influenza Coordinator elaboraram um plano estratégico para a redução dos riscos ligados às doenças infecciosas com potencial epidêmico e pandêmico de origem animal que aflijam serem humanos (FOOD AND AGRICULTURE ORGANIZATION, 2008).

A FAO coordena, ainda, um programa global para o controle e prevenção da gripe aviária altamente patogênica, causada pelo vírus H5N1 (FOOD AND AGRICULTURE ORGANIZATION, 2010). Dessa forma, percebe-se que a participação dessas instituições é importante especialmente no que diz respeito à agenda das doenças infecciosas emergentes.

A intensificação do tráfego de pessoas e bens e o estreitamento entre as cadeias produtivas da economia global fazem crescer o risco associado à propagação internacional das doenças infecciosas. Devido ao fato de que diversas dessas são transmitidas pela ingestão de alimentos contaminados, a aplicação de medidas de vigilância sanitária ligada ao comércio desses bens é fundamental. Por isso, outra instituição envolvida na governança das doenças infeciosas é a Organização Mundial do Comércio (OMC) cujo desafio nessa seara é garantir a segurança sanitária nas exportações e importações sem que isso prejudique o comércio internacional, assim como disposto pelo RSI (2005) - que reconhece que o controle das doenças infecciosas pode demandar de restrições comerciais.

Nesse contexto, os acordos da OMC sobre essa matéria funcionam não só no sentido de reduzir o risco de transmissão das doenças infecciosas pela via comercial, mas também de garantir que países não se valham de medidas sanitárias para colocar restrições ao comércio internacional. Essas são as diretrizes que orientam o acordo da Organização sobre medidas sanitárias e fitossanitárias (WORLD TRADE ORGANIZATION, 2014), que entrou em vigor em 1995 para garantir a segurança sanitária no comércio de alimentos, plantas e animais. Visando 
evitar que a aplicação dessas medidas sanitárias sejam utilizadas inadequadamente pelos países como formas de protecionismo, a OMC instaurou um comitê de notificação ao qual países que considerem que suas exportação sejam vitimas desse tipo barreira comercial possam recorrer. Esse comitê atua com base em informações científicas sobre a adequação da medida sanitária em face do risco à saúde colocado pelo agente patológico ou doença. Para isso, a OMC mantém por meio desse comitê relacionamento com a OMS, que provê recomendações técnicas para a avaliação de cada caso ${ }^{37}$.

Outras instituições internacionais também atuam na agenda de doenças infecciosas. Diferentemente da OMS, FAO e da OMC que são atores que contribuem para a construção normativa do regime internacional dessa agenda, diversas agencias do Sistema ONU tem programas e projetos sobre doenças infecciosas. Esse é o caso da UNESCO, UNICEF, UNAIDS e UNODC. A atuação dessas agencias juntamente com os Estados varia entre projetos de "capacity building", compartilhamento de informações, ações educativas com grupos específicos e apoio técnico para o desenvolvimento e implementação de políticas públicas que auxiliem no controle, prevenção e erradicação de doenças específicas. Nesse âmbito, chama atenção a prevalência da adesão dessas agencias especificamente ao combate à epidemia global de HIV/AIDS ${ }^{38}$.

Além dos Estados e organizações internacionais, também estão envolvidas na governança das doenças infecciosas outros atores: as organizações da sociedade civil. Dentre esses, é possível distinguir três grandes grupos: entidades científicas, fundações filantrópicas e empresa privadas transacionais.

O que orienta a atuação de entidades científicas na agenda das doenças infecciosas é o compartilhamento de informações. Associações acadêmicas congregam cientístistas, clínicos e outros profissionais da saúde especialistas em doenças infecciosas. Essas comunidades epistêmicas (HAAS, 1992) são relevantes nessa agenda, pois elas produzem conhecimento científico e normativo do assunto, o que subsidia a institucionalização do regime internacional em questão (RUGER, 2011, p.657). São exemplo dessas comunidades a Associação

\footnotetext{
${ }^{37}$ Para mais informações sobre a aplicação desse acordo, o funcionamento do comitê e de como informações técnicas da OMS contribuíram para a solução de controvérsias, consultar o relato detalhado da atuação desse comitê no caso das barreiras comerciais impostas pela União Europeia à importação de peixe da Tanzânia sob alegação de contaminação pelo agente causador da cólera, em 1998, disponível em "WTO Agreements and Public Health" (WORLD TRADE ORGANIZATION, 2002, p.60).

${ }^{38}$ Informações sobre as diversas agencias da ONU e suas atribuições no combate ao HIV/AIDS podem ser consultadas no link: <http://www.unaids.org/en/media/unaids/contentassets/documents/ document/2011/20110304_DoL_GuidanceNote_Summary_en.pdf>
} 
Americana de Microbiologia, Sociedade Americana de Doenças Infecciosas e a Sociedade Americana de Medicina Tropical e Higiene.

Por meio de incentivos à colaboração acadêmica, essas associações reconhecem a relevância do envolvimento internacional nessa matéria e participam da governança das doenças infecciosas. Dessa forma, essas entidades contribuem para o desenvolvimento acadêmico, científico e tecnológico nesse campo, ao mesmo tempo em que ajudam a projetar a voz das comunidades epistêmicas. Ademais, essas instituições participam de iniciativas internacionais de combate e controle das doenças infecciosas em parceria com governos e organismos internacionais, como por exemplo, a Stop TB Partnership (STOP TB PARTNERSHIP, 2014a).

As fundações filantrópicas tem desempenhado papel significativo no controle das doenças infecciosas. São exemplos dessas entidades: Bill and Melinda Gates Foundation, Rockfeller Foundation e a Ford Foundation. A fundação Bill and Melinda Gates, por exemplo, em 2009, figurou como terceiro maior doador para projetos de saúde global, atrás apenas dos EUA e do Fundo Global para o Combate à AIDS, Tuberculose e Malária (SMITH, 2011).

Apesar de a atuação dessas entidades na esfera da saúde global não se restringir à agenda de doenças infecciosas (STUCKLER et al., 2011), a maior parte dos investimentos feitos por essas instituições para saúde global é voltada para o desenvolvimento de vacinas, programas de controle, erradicação e imunização, produção de drogas e terapias, entre outros projetos relacionados com doenças comunicáveis epidêmicas e endêmicas nos países em desenvolvimento (SHIFFMAN, 2007).

Conforme aponta Moran (2007), recentemente, a atuação dessas fundações tem se estendido além do tradicional investimento em pesquisa e tecnologias para o combate às doenças infecciosas. Segundo autor, esses atores protagonizam a formação de "coalizões estratégicas" entre grupos da sociedade civil, empresas privadas transnacionais, organismos internacionais e governos, dando origem a arranjos inovadores conhecidos como parcerias público-privadas (MORAN, 2007). O advento dessas parcerias evidencia de que o envolvimento das fundações filantrópicas na agenda de doenças infecciosas vai além do seu já consolidado papel de prestadoras de assistência humanitária e de investimento em pesquisa.

Exemplos dessas iniciativas são: a Iniciativa Global para Erradicação da Polio, o Fundo Global para o Combate à AIDS, Tuberculose e Malária, Aliança Global para Vacinas e 
Imunização $^{39}$ (GAVI Alliance) e a Iniciativa Internacional de Vacina para AIDS. Essa última foi iniciada a partir de um projeto custeado pela Rockfeller Foundation ainda nos anos 1990, e serviu não só como referência para diversas outras parcerias público-privadas que seriam criadas a partir de então (MORAN, 2007), mas também como um modelo do envolvimento em governança em saúde global a ser adotado pelas fundações filantrópicas de empresas privadas.

É inegável o impacto das parcerias público-privadas na governança das doenças infecciosas. Até 2010, somente os programas implementados pela GAVI Alliance contribuíram para a prevenção de 5 milhões de futuras mortes causadas por doenças como febre amarela, pólio, rubéola, hepatite B, entre outras, investindo na vacinação de mais de 288 milhões de crianças, atingindo o maior índice de imunização global da história (LOBLEVYT, 2011; GAVI ALIANCE, 2010). A “Stop TB Partnership” dedicada ao combate à tuberculose, fundada em 2001, cuja missão é "servir às pessoas vulneráveis à tuberculose garantindo tratamento de alta qualidade" (STOP TB PARTNERSHIP, 2014b), é uma rede que atua em mais de 100 países agregando aproximadamente 1100 entidades - dentre organizações internacionais, científicas, governamentais, fundações filantrópicas, empresas privadas, órgãos governamentais de diversos países e organizações da sociedade civil.

A Iniciativa Global para Erradicação da Polio alia esforços da OMS, UNICEF, US Centers for Disease Control and Prevention, Rotary International, e da Bill and Melinda Gates Foundation em prol da erradicação da poliomielite em todo o mundo. A iniciativa agrega mais de 200 países, e, com investimento declarado de mais de 8.2 bilhões de dólares, já imunizou 2,5 bilhões de crianças contra a doença (THE GLOBAL POLIO ERRADICATION INITIATIVE, 2010).

Nesse sentido, essas parcerias público-privadas são iniciativas inovadoras, multisetoriais e descentralizantes que evidenciam a crescente importância da articulação entre Estados, organismos internacionais e organizações da sociedade civil. Ao se engajarem nesse modelo de atuação, as fundações filantrópicas ganham reconhecimento no campo da governança das doenças infecciosas.

Isso demonstra que o papel desempenhado pelas organizações da sociedade civil na governança das doenças infecciosas é bastante significativo (STUCKLER, 2011). Conforme discutem Ravishankar et al. (2009), o montante de recursos financeiros para a cooperação internacional na área de doenças infecciosas canalizados via agencias do Sistema ONU

\footnotetext{
${ }^{39}$ Detalhamento de todas as instituições e grupos envolvidos na GAVI Alliance pode ser consultado em: <http://www.gavialliance.org/About/Partners-in-the-Alliance/>
} 
decaiu, enquanto que a verba disponibilizada tendo como intermediário organizações da sociedade civil aumentou. A possível explicação para esse fenômeno, discutida por Doyle e Patel (2008), é que diversos países desenvolvidos tem preferido dedicar recursos para os projetos de cooperação nessa esfera às fundações filantrópicas e outros atores não-Estatais para evitarem lidar com a ineficiência de mecanismos intergovernamentais e com governos corruptos dos países recipientes, realidade ressaltada especialmente nos países africanos.

As organizações da sociedade civil também são relevantes na governança das doenças infecciosas quando concentram seus esforços nos países mais pobres, que mais carecem de recursos e políticas (SHIFFMAN, 2007). Exemplo desses esforços, discutido por Saxenien et al. (2011), é a atuação da GAVI Alliance facilitando a aquisição de vacinas pelos países de renda média e baixa. Além disso, conforme aponta Caines (2004), as parcerias públicoprivadas são responsáveis por investirem em programas e projetos de controle de doenças específicas que recebem pouca ou nenhuma atenção dos setores públicos e dos organismos internacionais, as chamadas doenças negligenciadas.

Por fim, conforme demonstra Sandberg (2010), as organizações da sociedade civil, articuladas na forma de parcerias público-privadas engajadas na governança das doenças infecciosas, não só contribuem com recursos financeiros e implementação de projetos, mas também são fatores importantes para a elaboração normativa dos regimes internacionais dessa matéria.

Contudo, a variedade de novos atores engajados nessa agenda traz à tona conflitos de interesse, especialmente entre empresas privadas transnacionais, fundações filantrópicas e organismos internacionais. Stuckler (2011) discute como as políticas de concessão de bolsas para pesquisa feito pelas fundações filantrópicas beneficia empresas privadas - como indústrias farmacêuticas e de alimentos - que nem sempre compartilham com aquelas os mesmos valores. Richter (2004) analisa como a OMS tem salvaguardado o interesse público na aproximação com as parcerias público-privadas - e em especial com empresas privadas.

Devido a essa disparidade entre os interesses das organizações internacionais, em termos de saúde pública global, e os das organizações da sociedade civil levantam preocupação quanto à legitimidade da atuação dessas instituições na governança das doenças infecciosas. Doyle e Patel (2008) explicam como o aumento da influencia desses atores perante os organismos internacionais, em especial na agenda de combate ao HIV/AIDS, é um desafio para a manutenção da legitimidade das políticas internacionais. Isso é agravado pela ausência de mecanismos reconhecidos de "accountability" nessas organizações, conforme avalia Caines (2004). 
O mapeamento realizado acima das principais políticas, normas e atores envolvidos na agenda de doenças infecciosas atualmente possibilita reconhecer que essa é objeto de governança global - a partir do vocabulário proposto por Fidler (2002). É notável que objetivos como o controle, combate, prevenção e erradicação das doenças infecciosas no mundo não é tarefa desempenhada exclusivamente pelos Estados e organizações internacionais.

Ao contrário, observa-se um aumento expressivo no número e na qualidade dos atores não-Estatais engajados nesse campo. Da mesma forma, a produção das normas e sua aplicabilidade e um exercício que tem sido cada vez mais compartilhado pelos Estados e OIs com outros atores - como, por exemplo, as fundações filantrópicas na forma de parcerias público-privadas ou outras iniciativas consultivas entre essas as OIs.

\subsubsection{Governança das doenças infecciosas emergentes}

O primeiro desafio, ao se estudar a governança das doenças infecciosas emergentes (DIEs), decorre da delimitação conceitual desse objeto. A tarefa de classificar quais das doenças infecciosas são emergentes não se limita em identificar novas patologias, avaliando, dessa forma, sua "emergência" significativas em relação a quais doenças se encaixam nessa nomenclatura.

Ao revisar a literatura sobre o tema, pode-se afirmar que os conceitos propostos de "doenças infecciosas emergentes" levam em conta, de maneira diferente, três critérios. O primeiro deles diz respeito à precedência da infecção humana por um determinado patógeno. Caso uma doença seja causada por um ente até então desconhecido, ou apenas recentemente identificado, ela é chamada de "emergente". O segundo critério diz respeito à dimensão geográfica do alcance da doença infecciosa. Uma doença é chamada de emergente quando ocorre em uma região em que não havia registros de casos nas últimas décadas - a despeito de ser causada por um agente patogênico já conhecido ou não. O terceiro critério é o tempo em que uma doença infecciosa afeta seres-humanos. Levando em conta esse critério, doenças infecciosas deixam de ser "emergentes" ao longo dos anos, podendo ser controladas, erradicadas ou se tornarem endêmicas.

\footnotetext{
${ }^{40}$ Vale esclarecer que o termo "emergente", conforme utilizado tanto nessa pesquisa quanto na literatura aqui referenciada - e especialmente quando incorporado na expressão "doenças infecciosas emergentes" - conota o sentido de "aquilo que aparece/surge" e não de "urgente".
} 
Observa-se que esses três critérios podem ser utilizados de maneira diferente ao classificar quais seriam consideradas doenças infecciosas emergentes. Por exemplo, segundo o critério da dimensão geográfica, a dengue na Flórida nos EUA, e em outras partes do mundo em que não haviam casos registrados (RADKE et al., 2012; MACKENZIE et al., 2004; GUBLER; CLARK, 1995), seria considerada como uma "doença infecciosa emergente" - a despeito dessa ser uma patologia conhecida há décadas, com um agente causador já identificado. Num outro exemplo, segundo o critério da precedência de infecção humana, a SARS, em 2003, é sem dúvidas uma doença emergente - porém, a mais de uma década depois, à luz do terceiro critério, ela deixa de sê-lo?

Essa problemática relacionada às classificações conduz à elaboração de conceitos incompletos ou de difícil operacionalização metodológica. A definição proposta pela OMS e pelo CDC (CENTERS FOR DISEASE CONTROL AND PREVENTION, 1998; WORLD HEALTH ORGANIZATION, 1998), também adotada por Fidler (1996, p.77; 1997a, p.18), dispõe que as doenças infecciosas emergentes são aquelas "cuja incidência em humanos aumentou nas últimas duas décadas ou ameaça aumentar no futuro próximo".

Apesar de esclarecer com precisão a dimensão temporal da emergência das patologias, essa definição fornece pouca informação sobre o quesito da precedência de infecção humana, por exemplo. Em outro documento, a OMS define DIEs como aquelas doenças que resultam de "infecções causadas por agentes recentemente identificados ou até então desconhecidos que causam problemas de saúde pública tanto local ou internacionalmente" (WORLD HEALTH ORGANIZATION, 1998, sp) - definição que carece de precisão quanto ao critério geográfico e temporal discutidos acima. Já na definição proposta por Morse (1995, p.7), as DIEs "são aquelas que apareceram pela primeira vez em uma população ou que já existiam, porém cuja incidência ou alcance geográfico aumentou rapidamente".

Apesar da ampla difusão desse conceito na comunidade acadêmica, ela não esclarece se é uma condição necessária ou não para considerar uma doença infecciosa como emergente essa ser causada por um agente patológico desconhecido ou apenas recentemente identificado.

A solução para essas incongruências conceituais talvez se dê ressaltando a diferença entre doenças infecciosas emergentes e reemergentes (DIERs), nomenclaturas recorrentes na literatura epidemiológica e que frequentemente aparece em publicações institucionais. A distinção entre essas duas categorias centra-se no primeiro critério: a precedência da infecção humana. Segundo Heymann (2009), DIEs são aquelas causadas em humanos por micróbios anteriormente desconhecidos ou que foram recentemente identificados. Já as "doenças infecciosas reemergentes" (DIRs) são causadas por agentes infecciosos já conhecidos que 
voltam a infectar uma população humana, ou que sofreram alguma alteração na sua composição genética - como, por exemplo, na suscetibilidade a drogas antibióticas - o que resulta em padrões epidemiológicos diferenciados (HEYMANN, 2009) ${ }^{41}$.

Nesse sentido, nessa pesquisa DIEs são aquelas causadas por agentes patológicos bactérias, vírus, fungos, protozoários, príons ou outros microrganismos - até então desconhecidos ou apenas recentemente identificados, que foram diagnosticadas em sereshumanos pela primeira vez. Essa definição se baseia no critério da precedência da infecção humana ao concordar com o conceito de "newly emerging infectious diseases" proposto por Fauci e Morens (2012, p.456) - “doenças que são reconhecidas em hospedeiros humanos pela primeira vez" - acrescentando a essa a condição de ser necessariamente causada por um novo agente infeccioso. São exemplos de doenças que se enquadram nessa conceituação de DIEs a SARS (2003), Influenza A H1N1 (2009) e a Síndrome Respiratória do Oriente Médio causada por coronavírus - MERS-CoV (2012).

Adotando essa definição, essa pesquisa defende que as DIEs, se tomadas como uma agenda específica, são objeto de governança internacional - diferentemente do que ocorre com as DIs em geral, que, como discutido anteriormente, opera numa dinâmica global. Duas considerações precisam ser feitas em relação a esse argumento. Primeiramente, afirmar que há governança internacional das DIEs não quer dizer que os Estados conseguem responder isoladamente na gestão desse problema coletivo (LOUGHLIN; BERRIDGE, 2002): implica, na verdade, em reconhecer que Estados e organismos internacionais são os atores com maior relevância, titularidade e que desempenham a maior parte das atividades no sistema internacional para abordar o problema (FIDLER, 2002).

Segundo, reconhecer a governança internacional das DIEs não implica em ignorar o impacto da globalização nessa matéria. Não há dúvida alguma de que o problema da emergência de novas patologias contagiosas seja agravado pela intensificação do trafego de pessoas e bens, por exemplo. Contudo, a gestão internacional desse problema ainda apresenta certa resistência ao aprofundamento da globalização política, no sentido de que resiste à inclusão de outros atores nessa matéria.

Por isso, não há atuação significativa de atores não-Estatais - além dos organismos internacionais - nesse âmbito. Diferentemente do que ocorre, por exemplo, com a governança

${ }^{41}$ É frequente o uso da expressão "doenças infecciosas emergentes e reemergentes" (DIERs) como uma categoria única para antepor-se às DIs endêmicas. Chamadas por Fauci e Morens (2012, p.456) de "stablished infectious diseases", as DIs endêmicas são aquelas doenças cuja prevalência por um período de tempo foi suficiente para a relativa estabilização e previsibilidade dos seus índices de mortalidade e morbidade diferentemente do que ocorre com as DIERs. 
de doenças como HIV/AIDS, malária, tuberculose, poliomielite e cólera, essas novas doenças não são objeto de trabalho de organizações da sociedade civil, como as fundações filantrópicas, parcerias público-privadas ou nem mesmo de empresas privadas transnacionais. Isso se deve principalmente à própria natureza desse problema.

O surgimento de novas doenças infecciosas é um fenômeno praticamente impossível de ser previsto. Há uma enorme variedade de doenças que podem infectar seres-humanos pela primeira vez. Essas doenças podem ser causadas por diversos tipos agentes patogênicos, em qualquer região do planeta, a qualquer momento e podem apresentar epidemiologias extremamente distintas quando comparadas entre si. Esses fatores dificultam - ou até mesmo inviabilizam - a formulação de planos de trabalho, a alocação de recursos financeiros e o planejamento para a vigilância, combate, controle e resposta às DIEs. Por isso, essas atividades seguem sendo desempenhadas quase que unicamente pelos próprios Estados e organismos internacionais ${ }^{42}$.

Ademais, a dimensão de emergência internacional em saúde pública associada com as DIEs orienta a compreensão dessa agenda como um tema de segurança. Como discutido ao longo do capítulo anterior, existem diversas abordagens para entender as doenças infecciosas como um assunto de segurança internacional. Especificamente no caso das DIEs, a noção de segurança internacional é ainda mais evidente.

O surgimento de novas doenças contagiosas é um fenômeno de gravidade por elas, na maioria das vezes, não terem tratamento determinado, e, logo, é bem provável que não haja medicamentos em estoque ou vacinas para imunizar grupos de risco, ou nem mesmo os profissionais de saúde estejam treinados para diagnosticar e orientar a prevenção dessa nova patologia. Por esses mesmos motivos, as DIEs podem causar epidemias em larga escala geográfica num curto período de tempo, constituindo uma ameaça à estabilidade dos Estados e a segurança sanitária das populações e à saúde dos indivíduos. É essa rationale que orienta, por exemplo, países desenvolvidos em proteger suas populações de epidemias de propagação internacional. Dessa forma, ao associar a dimensão de segurança às DIEs, os Estados em

\footnotetext{
${ }^{42}$ A versão em vigor do RSI (2005) oficializa a possibilidade de a OMS utilizar fontes não-oficiais (laboratórios, clínicas, centros de pesquisa e vigilância, etc.) para a obtenção de informações sobre epidemias e novas infecções, a despeito da autorização dos Estados-membros. Isso apontaria para a inclusão de diversos atores nãoEstatais no bojo da governança das DIEs e colocaria em questão a categorização dessa como governança internacional. No entanto, entende-se aqui que apesar de a inclusão dessa cláusula ser um avanço na gestão dessa agenda, a atuação dessas instituições não-oficiais ainda permanece atrelada à própria OMS que detém a prerrogativa legal no controle das DIEs internacionalmente. Esse assunto será discutido em detalhe no capítulo três dessa dissertação.
} 
alguma medida resguardam para si a gestão dessa agenda dificultando o compartilhamento dessa agenda política com demais atores internacionais.

Por fim, observa-se também que as normas internacionais que constituem o regime de controle e resposta às DIEs são resultado da atuação dos Estados e dos OIs. O principal marco jurídico nesse âmbito é sem dúvidas o RSI. Essa peça estipula como deve se dar a relação entre os Estados e a OMS na ocasião de emergências de saúde pública internacional e dessa forma estipula comportamentos, procedimentos e padrões de conduta internacionalmente reconhecidos para lidar com fenômenos ligados às DIEs. Além disso, o RSI é uma norma vinculante, o que, segundo Fidler (2002) é um dos indicativos de governança internacional.

Todos esses fatores nos levam a concluir que a agenda das DIEs parece não ter sido afetada - pelo menos não na mesma medida que outras agendas da saúde global - pela "revolução na governança em saúde global"43 (FIDLER, 2010, p.5). Essa diz respeito ao "aumento no número de instituições formais e informais engajadas na saúde global, produzindo uma explosão no número e tipo de atores procurando influenciar os resultados [...] gerando novos regimes e iniciativas [...], testemunhando aumento sem precedentes nos investimentos e causando a escalada da saúde global na política externa".

A descrição desse processo de "revolução" descreve com bastante propriedade o que tem ocorrido ao longo das últimas décadas com a agenda de controle das DIs - que presencia um exponencial aumento no número e na qualidade de atores envolvidos, o que complexifica os arranjos normativos e multiplica os fundos financeiros disponíveis e as políticas e programas em jogo. Contudo, o mesmo não ocorre quando se fala das políticas internacionais e dos regimes associados especificamente às DIEs que, apesar de terem se desenvolvido ao longo dos últimos anos - conforme será discutido no próximo capítulo- permanecem a cargo dos Estados e OIs.

\subsection{Conclusões: empregando modelos analíticos à análise empírica}

Este capítulo demonstrou que os desenvolvimentos recentes em torno do conceito de governança em saúde global acompanham as discussões sobre globalização e governança nas Relações Internacionais.

\footnotetext{
${ }^{43}$ De certa forma, essa "revolução" levaria à instauração de uma ordem pós-westfaliana, ou pós-internacional, em saúde global (FIDLER, 2003b; RICCI, 2009), em que os Estados perdem pelo menos parte de sua soberania para atores internacionais que se ocupam da governança em instâncias superiores ao território nacional.
} 
O principal ponto de contato entre essas linhas de pesquisa é a respeito da ascensão de novos atores - além dos Estados e dos organismos internacionais - e de novas formas de governar problemas coletivos. Esse também é o principal aspecto utilizado por Fidler (2002) para diferenciar os modelos de governança internacional e governança global. Segundo esse autor, em suma, a governança internacional seria aquela em que se observa a centralidade dos Estados e organismos internacionais na gestão dos problemas por meio de normas de caráter vinculativo.

A revolução na governança em saúde global, descrita por Fidler (2010), foi causada pelo envolvimento de outros novos atores na elaboração e implementação de políticas e normas internacionais de saúde global. Associações da sociedade civil, fundações filantrópicas, parcerias público privadas, empresas transnacionais, entre outras entidades, passaram a dividir espaço nessa área política com Estados e organismos internacionais, formulando também normas de caráter não-vinculativo - caracterizando, dessa forma, a governança global.

Em seguida, este capítulo procurou descrever a agenda de saúde global como uma coleção de diferentes temas que, quando agrupados sob esse conceito, dão forma a um emaranhado complexo de áreas de trabalho que compartilham entre si o fato de estarem diretamente relacionados com a saúde das populações a nível internacional. Demonstrou-se aqui, em seguida, que caracterizar essa agenda dessa maneira implica em reconhecer que não faz sentido rotular a saúde global como objeto de governança global ou internacional. Por isso, a aplicação dos conceitos de governança à análise empírica da agenda da saúde é problematizada nessa pesquisa ao se argumentar que há a necessidade de delimitação do objeto ao se estudar de que maneira ele é governada internacionalmente.

Isto posto, ao descrever, aqui, atores, programas políticos e principais normas internacionais relacionadas ao controle de doenças infecciosas, defende que essa "subagenda" da saúde global é objeto de governança global. A pesquisa procurou pinçar do grande escopo das doenças infecciosas o tema das doenças infeciosas emergentes. Para tanto, foram brevemente discutidas as dificuldades de conceituar esse objeto, apesar de isso não impossibilitar a compreensão das DIEs como uma agenda específica e passível de recorte metodológico. Isso é feito no sentido de demonstrar que a agenda das DIEs, tomada à parte, é mais bem caracterizada como sujeita à governança internacional.

Tendo isso claro, o próximo capítulo analisará como o regime de DIEs se desenvolveu ao longo da primeira década do século XXI. Para tanto, essa análise será informada pelos os modelos analíticos discutidos acima propostos por Oran Young (1999) e David Fidler (2002). 
Essa pesquisa será informada pelo esquema da dinâmica da governança da saúde global (figura 1) de Fidler (2002). No entanto, por ter sido discutido que as DIEs são sujeitas à governança internacional, é necessário restringir a dinâmica nesse âmbito apenas à metade "estatal" daquele diagrama.

Para essa pesquisa, os problemas globais importam apenas no sentido de que demandam reação por parte dos Estados que, por sua vez, internacionalizam o tratamento ao problema por meio da diplomacia. Esse processo dá origem ao direito internacional - na forma dos regimes internacionais - que voltam a incidir sobre os Estados, condicionando as respostas desses a esses problemas globais. Dessa forma, o exercício analítico realizado no terceiro capítulo limita-se à governança internacional - conforme caracterizada por Fidler (2002) - e não leva em consideração os atores não-Estatais nesse processo.

A teoria elaborada por Young foi selecionada para informar essa pesquisa por três motivos. Primeiro, esse modelo analítico é compatível com as acepções sobre governança proposta por Fidler (2002) e também seu entendimento da governança da saúde global como um complexo de regimes internacionais. Para ambos os autores, governança - seja ela internacional ou global - refere-se essencialmente a existência de regimes internacionais.

Segundo, o modelo teórico apresentado por Young contribui para a pesquisa ao discutir os tipos de regimes internacionais e da ordem estabelecida por eles bem como seus padrões de transformação que possibilitam aprofundar a análise dessa agenda. Além disso, os componentes dos regimes internacionais descritos por Young são ferramentas úteis na sistematização dessa pesquisa.

Por fim, a aplicabilidade da teoria de governança de Oran Young não se restringe à análise da governança internacional. Por isso, a adoção desse modelo analítico sobre governança possibilita o avanço futuro dessa agenda de pesquisa, a incluir objetos sujeitos à governança global.

Ou seja, a teoria de governança apresentada por Young serve à análise da governança internacional das DIEs, mas também possibilita a investigação de outras áreas, como, por exemplo, a governança global das doenças infecciosas. Isso é relevante, pois, sem dúvida, o aprofundamento dessa agenda de pesquisa se beneficiaria com a adoção um único escopo teórico, o que viabilizaria estudos comparativos, por exemplo. 


\section{GOVERNANÇA INTERNACIONAL DAS DOENÇAS INFECCIOSAS EMERGENTES}

O objetivo desse capítulo é compreender como se desenvolveu a governança internacional das doenças infecciosas emergentes ${ }^{44}$ (DIEs) nas últimas décadas. Para tanto, será analisado o surgimento e funcionamento do regime internacional de alerta, controle, prevenção e resposta a esses riscos.

A governança internacional das DIEs pode ser organizada para fins didáticos em dois grupos de atores e dispositivos: mediatos e imediatos. Os atores e dispositivos mediatos são aqueles cujas atividades não se referem diretamente às DIEs, mas acabam contribuindo para sua governança. Esse é o caso, por exemplo, da Organização Mundial do Comércio (OMC) que, grosso modo, é uma instituição preocupada com as trocas internacionais de bens e serviços, mas que cujo Acordo sobre Aplicação de Medidas Sanitárias e Fitossanitárias objetiva, dentre outras coisas, evitar a propagação de agentes infecciosos (AGINAM, 2002; FIDLER, 1997b, 1997c).

Diferentes organizações inseridas em outras agendas internacionais atuam indiretamente na governança das DIEs (DASILVA; IACCARINO, 1999), como é o caso da Organização para Saúde Animal (que se preocupa com o surgimento de novas cepas de vírus em animais que podem contaminar humanos), a Convenção Internacional de Aviação Civil (que, junto com a OMS, determina regras sanitárias em aeroportos e aeronaves), a Organização Marítima Internacional (que estipula diretrizes para evitar a transmissão de patógenos pela água de balastro de embarcações) e a União Postal Universal (que estipula protocolos para empacotamento de materiais biológicos).

Os atores e dispositivos imediatos são aqueles que detêm autoridade para atuar diretamente na agenda de DIEs. Diferentemente do que ocorre com a governança das DIs em geral - em que participam uma miríade de agências da ONU, Estados, ONGs e empresas privadas em parcerias internacionais - somente a Organização Mundial da Saúde (OMS) e os Estados se enquadram nesse critério. Devido às limitações inerentes a uma pesquisa de mestrado, serão analisados aqui apenas os atores e dispositivos imediatos na governança das DIEs. Apesar de reconhecer a importância que tem os que atuam indiretamente nessa agenda,

\footnotetext{
${ }^{44}$ Segundo definição discutida no capítulo dois dessa dissertação, as DIEs "são aquelas causadas por agentes patológicos - bactérias, vírus, fungos, protozoários, príons ou outros microrganismos - até então desconhecidos ou apenas recentemente identificados, que foram diagnosticadas em seres-humanos pela primeira vez" (p.79). Nesse capítulo, a expressão "novas doenças infecciosas" é utilizada algumas vezes com o mesmo significado.
} 
acredita-se que a investigação dos atores e dispositivos imediatos seja suficiente para compreender como se desenvolveu a governança das DIEs.

$\mathrm{O}$ argumento central defendido aqui é que o fortalecimento da governança internacional das doenças infecciosas emergentes observado a partir da década de 1990 se deu por meio da consolidação de um regime internacional sobre essa matéria. Essa consolidação ocorreu a partir da transformação do regime de controle de um grupo reduzido de doenças infecciosas (cólera, peste e febre amarela) em um regime abrangente sobre riscos internacionais à saúde pública - que incorpora as DIEs.

Para compreender como se desenvolveu a governança internacional das DIEs, essa pesquisa se restringirá à análise do Regulamento Sanitário Internacional (RSI), nas suas versões aprovadas em 1969 e $2005^{45}$. Esse documento é um tratado internacional vinculante elaborado sob os auspícios da Organização Mundial da Saúde. Por ser o único dispositivo internacional do tipo sobre esse tema, o tratado materializa o regime internacional sobre doenças infecciosas sendo a peça central na governança nesse âmbito.

A história desse acordo remonta às primeiras Conferências Sanitárias Internacionais, que ocorreram de 1851 a 1938. Em 1892, preocupados com a epidemia de cólera que se alastrava pela Europa, países adotaram a primeira Convenção Sanitária Internacional, que foi o primeiro acordo de alcance mundial sobre doenças infecciosas (FIDLER, 2005). Esse documento estipulava medidas de quarentena e inspeções médicas para garantir a contenção dos focos de cólera no Canal de Suez. Apesar de seu escopo limitado, a convenção serviu de base para a adoção de diversos outros tratados regionais e bilaterais sobre o controle de outras doenças infecciosas além da cólera.

Em 1948, foi criada a Organização Mundial da Saúde cuja primeira tarefa envolvia coordenar a elaboração e implementação de todas as normas internacionais nessa esfera (YOUDE, 2011). Os resultados disso surgirão em 1951, ano em que a Assembleia Mundial da Saúde - órgão decisório máximo da OMS - aprovou o texto original Regulamento Sanitário Internacional. Ao substituir doze acordos prévios, o tratado estabelecia regras internacionais para guiar as medidas de controle de seis doenças infecciosas - varíola, cólera, febre amarela, tifo, febre recorrente e peste.

A norma obrigava os países a adotarem procedimentos de higiene e inspeção em pontos de entrada. Essas obrigações eram consideradas pelo Regulamento as medidas máximas que poderiam ser aplicadas pelos países para conter a propagação dessas doenças, a

${ }^{45}$ Nesse capítulo, essas duas versões serão abreviadas por “RSI 2005” e "RSI 1969”. 
fim de evitar interferências indesejadas no comércio e tráfego internacionais. Além disso, o tratado determinava que os Estados signatários notificassem a ocorrência de casos dessas seis doenças em seus territórios à OMS. Em $1969^{46}$, o tratado foi atualizado e duas dessas doenças - febre recorrente e tifo - foram eliminadas da lista. Essa versão do regulamento permaneceu em vigor até 2007, quando foi substituída pela sua edição revisada, o Regulamento Sanitário Internacional aprovado em 2005. Essa versão é fruto de um longo e intenso processo de revisão, iniciado em 1995, que ampliou, reestruturou e atualizou completamente os objetivos, procedimentos e métodos desse regime. O objetivo dessa pesquisa é compreender como isso ocorreu demonstrando de que forma esse processo contribuiu para a governança internacional das DIEs.

A rigor, o Regulamento Sanitário Internacional de 1969 não pode ser considerado parte da governança das DIEs, pois esse tratado é aplicável apenas a uma lista determinada de doenças infecciosas já conhecidas. Em outras palavras, o RSI 1969 é um regime de controle apenas para cólera, febre amarela e peste negra. É apenas com a aprovação do RSI 2005 que se pode considerar que há um regime que inclua as DIEs, visto que essa versão não aborda doenças específicas, mas sim "emergências de saúde pública de importância internacional" (WORLD HEALTH ORGANIZATION, 2006, p.20), dentre as quais estão incluídas o surgimento de DIEs. Por isso, a análise do RSI 1969 é fundamental para compreender como se desenvolveu a governança internacional das DIEs, especialmente com o surgimento de um regime dessa agenda com a adoção do RSI 2005.

Aliado a isso, mesmo antes da aprovação da versão revisada em 2005, a própria OMS já reconhecia que o RSI 1969 era o framework legal para suas atividades de vigilância e resposta às DIEs, apesar de sua limitação a uma lista de doenças (WORLD HEALTH ORGANIZATION, 2001a; 2003c). Como será discutido nesse capítulo, a partir da década de 1990, a OMS coordenará a comunidade internacional no desenvolvimento de novas atividades para lidar com o risco das DIEs. Isso significa que, nos anos anteriores a aprovação do RSI 2005, já se observavam as tendências de desenvolvimento da governança das DIEs mesmo na ausência de um dispositivo legal para essa matéria.

Para analisar o Regulamento Sanitário Internacional, será adotado o modelo analítico proposto por Young (1980), já apresentado no segundo capítulo desta dissertação. Segundo

\footnotetext{
${ }^{46}$ Também foi nesse ano que o documento foi renomeado de "International Sanitary Regulations" (1951) para "International Health Regulations" (1969). Essa distinção não faz diferença na língua portuguesa, pois as versões de 1951, 1969 e 2005 foram todas traduzidas como "Regulamento Sanitário Internacional", como se adota aqui. Contudo, é por esse motivo que a literatura acadêmica e institucional, costuma se referir ao tratado do ano de 1969, e não ao de 1951, que contém o texto original.
} 
esse autor, para analisarmos a governança internacional, devemos nos voltar para os regimes internacionais. Esses são formados por três componentes: substantivos, processuais e de implementação.

O componente substantivo refere-se à coletânea de normas que definem direitos e deveres a serem observados por seus membros. Essas normas podem ser categorizadas em dois grupos distintos: direitos ou regras. Os direitos dizem respeito ao quê um determinado ator tem o poder de ocupar um papel reconhecido e legítimo. As regras são padrões de comportamento ou diretrizes bem-definidas que orientam o comportamento de um determinado grupo de atores pertencentes ao regime.

Para garantir sua funcionalidade, todas as regras de um regime devem descrever a qual grupo de atores ela se dirige, a prescrição do comportamento e a especificação de em quais circunstâncias a regra deve ser aplicada. As regras ainda podem ser de três tipos distintos: de uso (quando se referem à apropriação de recursos ou à limitação ao consumo dos mesmos, etc.); de responsabilidade (quando estabelecem normas de compensação e/ou reparação decorrente de danos a outros atores); e, de procedimento (que descrevem como devem ser resolvidas disputas em âmbitos organizacionais).

O componente processual dos regimes internacionais abrangem "mecanismos reconhecidos para a resolução de situações que envolvem escolhas sociais ou coletivas" (YOUNG, 1980, p.336). Esses mecanismos desempenham processos de tomada de decisões e para a resolução de problemas que surgem quando um regime internacional entra em operação. Esses problemas podem ser em relação à alocação e distribuição de recursos, à resolução de conflitos entre as partes ou até mesmo à aplicação das próprias normas que fundam o regime. Em suma, nessa pesquisa, todos os elementos que descrevem como o regime deve funcionar - em termos de procedimentos e protocolos - foram considerados componentes processuais.

O terceiro componente dos regimes internacionais diz respeito à implementação de suas normas. Young (1980, p.338) argumenta que o bom funcionamento dos regimes é tarefa difícil de ser alcançada, pois frequentemente os atores podem resistir ao cumprimento das regras ou em aceitar as decisões dos mecanismos de escolhas sociais. Nesse sentido, a efetividade de um regime internacional está diretamente relacionada com a sua capacidade de fazer serem seguidos determinados padrões de comportamento pelos atores, implementando as regras por ele estipuladas. Segundo Young (1980, p.338), para garantir sua efetividade, os regimes devem criar incentivos para requerer dos atores a observância às normas. Nessa pesquisa, foram considerados componentes de implementação do regime os atores que 
aplicam as normas, garantem a operação do regime, e/ou criam incentivos para seu funcionamento adequado.

Como todo tratado internacional, o RSI é um conjunto de regras, ou seja, uma coletânea de componentes substantivos - pois reúne normas sobre direitos e deveres em relação a um assunto específico. Contudo, ao dispor os componentes substantivos, o RSI também revela quais são os procedimentos do funcionamento e os atores envolvidos na operação do regime. Por isso, essa pesquisa tratou esse documento como um mapa para encontrar os componentes substantivos, processuais e de implementação do regime de controle das DIEs. Uma vez identificados e analisados todos esses componentes nos regimes instituídos pelos RSI 1969 e 2005, espera-se que seja possível observar de maneira sistematizada as inovações ocorridas nesse regime e, logo, compreender de que forma se desenvolveu a governança internacional das DIEs.

\subsection{Regulamento Sanitário Internacional (1969)}

O Regulamento Sanitário Internacional (1969) é um tratado internacional vinculante cujo texto foi aprovado após uma série de negociações multilaterais articuladas pela Organização Mundial da Saúde ${ }^{47}$, e que vigorou até 2005. O objetivo desse tratado é "garantir a máxima segurança contra a propagação de doenças infecciosas com mínimo de interferência no tráfego internacional" (WORLD HEALTH ORGANIZATION, 1983, p.5). Para tanto, o Regulamento estipula um conjunto regras e diretrizes - acerca das medidas de saúde pública e de vigilância sanitária e epidemiológica - que devem ser adotadas pelos Estados signatários visando

\footnotetext{
fortalecer o uso de princípios epidemiológicos aplicados internacionalmente, para detectar, reduzir ou eliminar as fontes das quais uma infecção se propaga, melhorar as condições sanitárias nos portos e aeroportos e em suas redondezas, prevenir a disseminação de vetores e, em geral, encorajar atividades epidemiológicas no nível nacional para que seja reduzido o risco de novas infecções vindas de fora (WORLD HEALTH ORGANIZATION, 1983, p.5).
}

Essas atividades indicam a abrangência da aplicação do RSI pelos Estados e pela OMS para contenção das doenças infecciosas. Contudo, apenas quatro doenças estavam sujeitas a essa norma: peste, cólera, febre amarela e varíola, sendo que essa última foi eliminada da lista

\footnotetext{
${ }^{47}$ O texto original do RSI 1969 recebeu duas emendas aprovadas pela Assembleia Mundial de Saúde da OMS: em 1973, a respeito particularmente às provisões para controle da cólera; e, em, 1981, para exclusão da varíola do grupo das doenças sujeitas ao documento, em ocasião de sua erradicação global.
} 
em 1981, em ocasião de sua erradicação global. Ao longo de séculos, essas doenças colocaram obstáculos para a saúde das populações e estabilidade das sociedades, ocasionando até mesmo disputas e conflitos internacionais. Isso ajuda a compreender por que elas são objetos desse tratado (ANDRUS, 2010). No entanto, não parece haver dúvidas na literatura contemporânea de que esse escopo reduzido para aplicação do Regulamento foi uma das principais limitações para o regime de controle das doenças infecciosas (GOSTIN, 2004; HARDIMAN, 2003; AGINAM, 2002; FIDLER, 2003a).

Essas limitações foram agravadas com o surgimento de novas doenças desde a adoção do RSI 1969. Segundo Price-Smith (2002), desde 1975 foram identificadas pelo menos 33 novos agentes patogênicos. Dentre esses, encontram-se os causadores de doenças responsáveis por epidemias globais de enorme impacto econômico e social, como o $\mathrm{HIV}$, rotavírus ${ }^{48}$ e a Legionella $^{49}$, além de vírus cuja alta virulência e mortalidade desafiam sistemas de saúde e a segurança epidemiológica de populações hoje, como é o caso do vírus do ebola.

\subsubsection{Componentes substantivos no RSI 1969}

Os componentes substantivos do regime estipulado pelo RSI 1969 correspondem às regras de conduta a serem adotadas pelos Estados-parte e pela OMS. Essas normas são aplicadas quando da ocorrência de casos de doença infecciosa objeto do tratado (ou do seu agente causador) ou da suspeita e/ou confirmação de contaminação de pessoas em trânsito, veículos de mobilidade internacional e/ou de suas cargas e bagagens. Com esse escopo, essas regras podem ser separadas em dois grandes grupos: (a) sobre o compartilhamento da informação epidemiológica; e, (b) sobre organização das capacidades de saúde e medidas sanitárias.

a) Compartilhamento de informação epidemiológica

Em relação ao primeiro grupo, o RSI 1969 firma uma série de normas procurando garantir que os Estados-parte disponibilizarão todas as informações sobre as três doenças em questão à OMS. Dentre essas normas, estão aquelas que obrigam os Estados-parte notificar à OMS a ocorrência de casos de doenças objeto do Regulamento e da sua confirmação diagnóstica; a existência dos agentes patogênicos em vetores, além do homem; as medidas

\footnotetext{
${ }^{48}$ O rotavírus é o maior responsável pelos casos de diarreia infantil no mundo (SATCHER, 1995).

${ }^{49}$ Bactéria causadora de pneumonia de alta taxa mortalidade (BARRETT et al., 1998).
} 
adotadas para garantir a segurança sanitária em áreas infectadas; dentre outras. Em complementariedade, o Regulamento estipula que a OMS compartilhará com os Estados-parte todas as informações por ela recebidas.

Essas normas procuram garantir que os países tenham conhecimento da ocorrência de casos ou de epidemias das doenças em outras partes do mundo cuja transmissibilidade entre fronteiras é um risco para suas populações. Dessa forma, de posse dessa informação, os Estados podem entrar em "estado de alerta"50 e tomar medidas necessárias para garantir a segurança sanitária em seus territórios. Faz sentido supor que seja esse raciocínio dos Estados-parte, num cenário de aumento do comércio internacional e do tráfego de pessoas ao longo de toda a segunda metade do século $\mathrm{XX}$, e, especialmente, nas suas últimas décadas. Nesse contexto, o compartilhamento da situação epidemiológica entre todos os Estados-parte intermediada pela OMS busca evitar, pelo menos em tese, a "importação das doenças infecciosas" (WORLD HEALTH ORGANIZATION, 2002, p.3), garantindo a segurança sanitária dentro dos países.

No entanto, desde a entrada em vigor do tratado em 1969, percebeu-se que os Estadosparte demonstraram grande resistência em notificar casos das doenças à OMS. Em alguns casos, países tiveram dificuldades em reportar em prazo hábil ou o fizeram com informações incompletas. Diversos autores discutem a falta de incentivos para que os Estados agissem em conformidade com o Regulamento.

A decisão de um país sobre notificar ou não a ocorrência de um surto de determinadas DIs em seu território leva em consideração, dentre outras variáveis, os temores das consequências econômicas de tal ação. Youde (2011, p.816) afirma que reconhecer a presença dessas doenças dentro de suas fronteiras poderia trazer "efeito devastador para a economia, o turismo e a reputação perante a comunidade internacional”. Laxminarayan et al. (2014) demonstram que o impacto nos setores de comércio e do turismo estão entre os principais fatores que desincentivam os países a notificar. Na mesma linha, Heymann (2009, p.1266) aponta que, ao causarem a redução da produtividade, comércio e das atividades turísticas, as epidemias podem "devastar setores da economia".

Dois casos ilustram a associação entre a notificação e as consequências econômicas. Em 1991, uma epidemia de cólera no Peru gerou perda de cerca de 700 milhões de dólares na balança comercial desse país, devido a embargos e restrições do turismo (YOUDE, 2011). Em

\footnotetext{
${ }^{50}$ O RSI 1969 não adota a expressão "estado de alerta", ou nenhum outro termo equivalente. Contudo, faz sentido supor que essa seja a reação lógica dos Estados-parte para se proteger da entrada de doenças infecciosas em seus territórios.
} 
1994, a epidemia de peste em Surat, na Índia, causou a perda de 1.7 milhões de dólares (AGINAM, 2002, p.947). Em ambos os casos, os governos desses países agiram na contramão do que estipulava o RSI 1969 em vigor e fizeram o máximo para impedir que a informação sobre essas doenças fosse disseminada. E, quando o fizeram, foram incapazes de reunir informações confiáveis em tempo hábil, devido à precariedade de laboratórios qualificados e mecanismos de vigilância adequados - agravando ainda mais o cenário de alarme das populações locais e da comunidade internacional.

Essas experiências demonstram que os prejuízos econômicos trazidos pela notificação de surtos desestimulam os Estados a agir em conformidade com o regime. Esse é um dos motivos pelos quais o objetivo do RSI 1969 prioriza garantir a mínima interferência no tráfego internacional - especialmente no comércio (FIDLER; GOSTIN, 2006). Abordar a interface entre doenças infecciosas e comércio internacional é fundamental não só para reduzir das perdas econômicas, mas também para garantir a efetividade do regime em questão, criando condições para que os Estados notifiquem e garantias de que eles não sofrerão represálias econômicas por isso. Nesse sentido, os princípios de "segurança máxima" e "interferência mínima” são complementares (TIGERSTROM, 2005, p.42). Contudo, conforme será discutido adiante, os dispositivos legais presentes no RSI 1969 não foram suficientes para restringir as medidas adotadas pelos países para contenção das doenças em questão.

Além da dimensão dos impactos econômicos, o compartilhamento de informações dessa natureza também traz à tona desafios políticos. As experiências de Peru e Índia comprometeram não só a observância em geral às normas de compartilhamento de informações epidemiológicas, mas também o compromisso dos Estados com o sistema de vigilância proposto pelo RSI 1969. Outros países, observando as consequências das sofridas por esses dois países, provavelmente estarão ainda mais relutantes em reportarem casos de doenças no futuro (CASH; NARASIMHAN, 2000). Isso demonstra que o compartilhamento de informações epidemiológicas é uma atividade que envolve avaliações políticas sérias que podem comprometer a eficácia do regime.

A questão das notificações de casos de doenças traduziu-se em tensões políticas durante primeiros meses da epidemia mundial de SARS em 2003. Acredita-se que a epidemia tenha começado em meados de novembro de 2002, na província de Guangdong, China (WORLD HEALTH ORGANIZATION, 2004c). Contudo, foi somente em fevereiro de 2003 que o governo chinês reportou à OMS os primeiros dados de diagnóstico. No mês seguinte, a propagação da epidemia era tamanha que casos de infecção já haviam sido identificados em 
pelo menos 15 países (WORLD HEALTH ORGANIZATION, 2003b). Ainda assim, o país tentou acobertar a extensão e gravidade do surto, provendo à OMS informações com números falsos e escondendo pacientes da doença dos hospitais na ocasião da visita de técnicos da Organização (CNN, 2003).

Em abril de 2003, a OMS acusou publicamente a China de negar informações sobre os avanços da doença ao público. Somente em abril de 2003 os líderes chineses ordenaram às autoridades de saúde que deixassem de acobertar a situação da epidemia de SARS no país, dando início a um programa emergencial de contenção do vírus em todo o país (FIDLER, 2003b).

Esses casos deixam claro que as disposições normativas no RSI 1969 sobre o compartilhamento internacional de informações epidemiológicas são insuficientes. O RSI 1969 não contempla a infraestrutura necessária de vigilância epidemiológica, restringindo-se a afirmar a obrigação dos Estados em notificar a ocorrência de uma doença objeto do regulamento (BAKER; FIDLER, 2006, p.1060). Além disso, o Regulamento não dispõe de incentivos ou garantias nem provê instrumentos coercitivos para garantir que os Estados-parte contribuam.

Observou-se, também, que a notificação é uma atividade politicamente sensível, devido às severas consequências socioeconômicas às quais os países notificantes são submetidos. Como será analisado posteriormente, a comunidade internacional percebeu, ao avaliar do funcionamento do RSI 1969, que não se pode depender exclusivamente da voluntariedade dos Estados-parte nessa questão.

\section{b) Organização das capacidades de saúde e medidas sanitárias}

A maior parte do texto do RSI 1969 é dedicada à organização das capacidades de saúde e às medidas sanitárias que devem ser realizados para a contenção das doenças infecciosas. Esses temas são objeto das partes III e IV do Regulamento, sendo que a parte V dá continuidade a essa matéria ao abordar as provisões específicas para cada uma das três doenças em questão.

A sessão dedicada à organização das capacidades de saúde descreve qual a infraestrutura os Estados-parte devem ter instaladas nos seus pontos de entrada para "garantir que portos e aeroportos no seu território tenham, a sua disposição, a organização e o equipamento adequado para a aplicação das medidas providas no Regulamento" (WORLD HEALTH ORGANIZATION, 1983, p.15). Dentre esses requisitos, estão os de determinar 
áreas de trânsito de passageiros, veículos e cargas internacionais, dispor de autoridades portuárias e profissionais de inspeção sanitária, equipes médicas, zonas para isolamento e quarentena, instalações para vacinação contra febre amarela, entre outros.

As medidas e procedimentos de saúde estipulados pelo Regulamento são "as medidas máximas aplicáveis ao tráfego internacional” (WORLD HEALTH ORGANIZATION, 1983, p.18). Para a OMS, é importante descrever quais são as medidas máximas aplicáveis ao tráfego internacional para evitar que, durante uma epidemia, os países tomem decisões exageradas, sem base científica suficiente, o que poderia ser danoso para o país afetado (WORLD HEALTH ORGANIZATION, 2002, p.3).

Por isso, essas disposições de caráter técnico estão detalhadas do artigo 23 ao 80, para orientar as administrações de saúde nos países, autoridades sanitárias e portuárias e os comandantes de embarcações sobre como proceder com respeito à emissão de documentos (como certificados de vacinação, inspeção e derratificação, etc), vigilância de pessoas sob suspeita de contaminação, realização de exames médicos, impedimento de viajantes contaminados de embarcarem, declaração de isolamento e quarentena de indivíduos e embarcações, entre outros.

Dessa forma, percebe-se que as normas estipuladas pelo RSI 1969 acerca das capacidades de saúde necessárias e as medidas sanitárias são destinadas à estruturação da infraestrutura e padronização das rotinas de trabalho especificamente nos pontos de entrada ${ }^{51}$.

No Regulamento, não há qualquer regra sobre a infraestrutura recomendada ou as atividades que os Estados devem desempenhar no âmbito da saúde pública para conter as doenças infecciosas dentro de seus territórios - a não ser a respeito do espaço geográfico que circunscrevem pontos de entrada. Não há, por exemplo, obrigações ou recomendações sobre capacidades laboratoriais, programas de vigilância epidemiológica nacional, acesso aos serviços de saúde ou planos de imunização da população. Conforme crítica de Hardiman (2012), essas capacidades seriam necessárias para instauração de sistemas nacionais de saúde efetivos para preverir a propagação internacional das DIs e de outros riscos.

Isso demonstra que o RSI 1969 limitava-se a questões de higiene portuária e procedimentos a serem seguidos em todas as fases e situações do tráfego internacional de pessoas e veículos. Essa limitação evidencia que o objetivo e escopo desse tratado é a contenção das epidemias nas fronteiras, e não na sua origem. Dessa forma, percebe-se que o

\footnotetext{
${ }^{51}$ A versão em inglês do RSI 1969 utiliza a expressão "points of entry", que foi traduzida para o português como "pontos de entrada", e significa "um local para entrada ou saída internacional de viajantes, bagagens, cargas, contêiner, meios de transporte, mercadorias e encomendas postais, bem como as agencias e áreas que prestam serviços a eles na entrada ou saída do território nacional" (WORLD HEALTH ORGANIZATION, 1983, p. 16).
} 
Regulamento configura uma estratégia de governança horizontal dos germes (FIDLER, 2004) das doenças infecciosas.

Essa abordagem identifica os Estados como os únicos atores com titularidade no tratamento da questão e percebe as doenças infecciosas como problemas exógenos a esses que devem ser contidos nas fronteiras. Conforme é o caso do RSI 1969, os instrumentos normativos de governança horizontal não contemplam como os Estados devem se organizar em âmbito doméstico ao lidar com esses problemas, mas apenas na medida em que afetam outros países.

Contudo, o RSI 1969 falhou em garantir que medidas de saúde exageradas fossem adotadas pelos Estados-parte. Conforme diversos analistas avaliam, os países não observaram essas normas no contexto de epidemias de propagação internacional (TIGERSTROM, 2005; BAKER; FIDLER, 2010, p.1060). Durante a epidemia de cólera no Peru em 1991, diversos países adotaram procedimentos de inspeção restritivos e impuseram restrições de viagens e de importações de certos produtos, a despeito de declarações feitas pela OMS de que não havia necessidade sequer base científica para tais medidas.

Situação semelhante ocorreu durante a epidemia dessa mesma doença no ocidente africano, em que a União Europeia mais uma vez baniu as importações de peixes provenientes dos países afetados. Em 1994, a suspeita de casos de peste negra em Surat na Índia já foi suficiente para que inúmeros países cancelassem voos, proibissem importações, fechassem fronteiras para turistas e nacionais indianos e divulgassem recomendações de viagem. Além desses exemplos, houveram ainda outros casos de países impondo medidas superiores às previstas no RSI 1969 para doenças fora do escopo do tratado, como foi o caso do banimento de importação de carne feito pela União Europeia devido aos riscos de encefalopatia espongiforme bovina (LOPPACHER; KERR, 2005), e dos impedimentos de acesso de indivíduos portadores de HIV/AIDS (ALLIN, 1988).

\subsubsection{Componentes de implementação no RSI 1969}

Os componentes de implementação identificados no RSI 1969 - ou seja, as estruturas ou atores responsáveis pela aplicação de normas e decisões do regime - são os Estados-parte - representados nas figuras de suas autoridades portuárias ou chefes das administrações de saúde - e a própria OMS. Não há qualquer menção no tratado sobre organizações nãogovernamentais, associações acadêmicas e/ou científicas ou empresas transnacionais. Isso reafirma o caráter internacional da governança das doenças infecciosas que esse regime ajuda 
a configurar, conforme discutido no capítulo anterior. Ademais, vale citar que o Regulamento também não faz qualquer referência a outros organismos além da OMS ou a regimes internacionais em que esses poderiam estar envolvidos.

Dessa forma, o regime configurado pelo RSI 1969 reconhece exclusivamente os Estados-parte como os únicos responsáveis com legitimidade para notificar casos de doenças. Se tomado a rigor, percebe-se que o modelo de vigilância epidemiológica estabelecido pelo RSI 1969 restringe-se apenas às autoridades nacionais de saúde e à OMS. O tratado ignora a participação na vigilância epidemiológica de qualquer instituição não-oficial - como laboratórios privados, organizações não-governamentais, grupos ou redes de pesquisadores.

\subsection{Ascenção da estratégia "global health security"}

Na década de 1990, as doenças infecciosas emergentes ganharam importância entre as comunidades de saúde pública internacional, políticos e pesquisadores (FIDLER, 1997a, 1997b). Ao lado de temas como a resistência antibiótica, a reemergência de doenças e o bioterrorismo, o surgimento de novas doenças será considerado assunto de segurança da saúde pública. Aliado a isso, a percepção de que o RSI 1969 havia "perdido a capacidade de garantir a segurança da saúde pública" (HEYMANN, 2009, p.1270) levará a OMS a reestruturar sua atuação nessa área.

Em 1995, a Assembleia Mundial da Saúde aprovou resolução intitulada "Communicable diseases prevention and control: new, emerging, and re-emerging infectious diseases" (WORLD HEALTH ORGANIZATION, 1995). Nesse documento, os Estadosmembros da OMS reconhecem o risco internacional que o surgimento de novas doenças infecciosas representa, bem como do reaparecimento daquelas já controladas, e apontam para a necessidade de um sistema de vigilância global para monitorar, avaliar e responder a essas ameaças. Para lidar com esses problemas, a resolução roga aos países que fortaleçam seus programas de vigilância domésticos e requer que a OMS estabeleça "estratégias para melhorar o reconhecimento e resposta às novas, emergentes e reemergentes, doenças infecciosas" (WORLD HEALTH ORGANIZATION, 1995a).

Com esse objetivo, a resolução demanda que a OMS elabore planos nacionais e internacionais para estruturar sistemas de vigilância e desenvolva estratégias que permitam para investigar e combater o surgimento de doenças infecciosas, em nível nacional e internacional, coordenando a iniciativa global nessa agenda juntamente com outras agencias da ONU, organizações não-governamentais, Estados e outros grupos interessados. Para 
desempenhar essas atividades, a OMS criou, ainda em 1995, a Divisão de Vigilância e Controle de Doenças Virais e Bacterianas, que mais tarde deu origem a dois departamentos: o Departamento de Vigilância e Resposta às Doenças Comunicáveis (CSR); e, o Departamento de Alerta e Resposta às Epidemias e Pandemias (EPR).

Para fortalecer o sistema de vigilância epidemiológica, a OMS desenvolveu uma nova abordagem de monitoramento denominada "outbreak verification" "52. Essa estratégia objetiva melhorar o controle às epidemias ao "coletar e verificar informações sobre surtos e informar autoridades de saúde pública sobre aquelas que são de relevância internacional" (Framework, 2000, p.4). Dessa forma, esse é um mecanismo de compartilhamento de informações epidemiológicas que envolve todas as doenças infecciosas - inclusive casos de doenças ainda não conhecidas -, e não apenas as que são objeto do RSI 1969.

Após coletar e processar notícias sobre casos de doenças de diversas fontes, essas informações são então compartilhados pela Outbreak Verification List, uma lista de e-mails distribuída semanalmente para mais de 900 parceiros da OMS - dentre agencias da ONU, autoridades de saúde pública dos países, epidemiologistas e ONGs. Posteriormente, depois de analisadas, essas informações são divulgadas em outras duas publicações abertas editadas pela OMS: o Disease Outbreak News e o Weekly Epidemiological Records.

A partir da década de 1990, os avanços nas telecomunicações permitirão o surgimento das redes de monitoramento global de DIs. Essas redes são responsáveis por alimentar bancos de dados sobre a ocorrência de casos de doenças. A OMS instituiu diversas dessas redes para o combate à doenças específicas, como, por exemplo a FluNet, RabNet, DengueNet, Global Tuberculosis Database e o Global Malaria Programme. Além desses exemplos que abordam doenças específicas, também surgiram iniciativas como o ProMED-mail, rede gratuita que reúne mais de 40.000 assinantes em mais de 150 países, que facilita a divulgação sobre casos de DIs desde 1993 (CASTILLO-SALGADO, 2010).

Essas redes também atuam na vigilância de novas doenças infecciosas. Em parceria com o governo do Canadá, a OMS desenvolveu a Global Public Health Intelligence Network para identificar casos de DIS, surtos e epidemias incomuns, com alto potencial de propagação e o surgimento de novas doenças. Essa rede é um sistema online que monitora constantemente a web, dedicando atenção especial para sites de veículos de comunicação, em busca de informações sobre casos de DIs de toda natureza. Essas informações são mantem informadas autoridades responsáveis que avaliam o risco de propagação internacional.

\footnotetext{
${ }^{52}$ Uma possível tradução para essa expressão seria "verificação de surtos".
} 
Em face da multiplicação dessas redes de monitoramento, a OMS garantiu sua centralidade não só colaborando com essas iniciativas, mas também com a criação da "Global Outbreak Alert and Response Network" (GOARN), em 1997, e sua posterior oficialização em 2000 (CALAIN, 2007). A GOARN é definida pela OMS como a "rede global das redes de vigilância epidemiológica" (CASTILLO-SALGADO, 2010, p.6; HEYMANN, 2009, p.1272), pois congrega "instituições que reúnem recursos humanos e técnicos para a rápida identificação, confirmação e resposta a surtos [de DIs] de importância internacional" (WORLD HEALTH ORGANIZATION, 2002, sp).

Ademais, a rede também objetiva garantir que assistência técnica apropriada seja disponibilizada aos países afetados rapidamente e contribuir para o desenvolvimento de capacidades em longo prazo para a prevenção de epidemias. Diversos tipos de atores que fazem parte dessa rede: instituições científicas, iniciativas médicas de vigilância, redes regionais e redes de laboratórios, agencias da ONU, e organismos não-governamentais de assistência humanitária (Médicos Sem Fronteiras, International Rescue Committee, etc.). Apenas no intervalo entre julho de 1998 e agosto de 2001, a GOARN verificou 578 surtos em 132 países. As doenças mais frequentemente notificadas pela rede nesse período foram cólera, meningite e febre hemorrágica.

Em 1995, teve início a revisão do RSI 1969, reconhecendo as críticas sobre a ineficácia e limitação desse tratado (FIDLER, 1996). Na resolução aprovada pela Assembleia Mundial da Saúde que dá início a esse processo (WORLD HEALTH ORGANIZATION, 1995b), ressaltou-se que a contínua evolução dos agentes infecciosos e o surgimento de novas doenças é uma ameaça à saúde pública que deve ser observada no novo regulamento.

Nesse sentido, a decisão de revisar o regulamento consagra a percepção da comunidade internacional da necessidade de atualizá-lo a fim de abordar o risco colocado pelas DIEs. Durante o processo de revisão, a OMS apontou que o Regulamento deve ser o dispositivo legal que orienta as suas atividades de "alerta e resposta às epidemias". Por isso, a nova versão desse tratado deveria contemplar três pontos: (1) garantir que apenas os riscos à saúde pública que sejam de importância internacional sejam notificados; (2) evitar a estigmatizarão e o impacto negativo no tráfego e comércio internacional devido às notificações inválidas; e, (3) assegurar que o sistema de vigilância seja sensível o suficiente para identificar novos riscos à saúde pública, como, por exemplo, novas doenças infecciosas (WORLD HEALTH ORGANIZATION, 2001a).

A decisão de atualizar o RSI 1969, a reorganização da OMS com o tema das DIEs e o surgimento de novas formas de monitoramento epidemiológico representam avanços para 
governança das DIEs. Esses avanços respaldaram a elaboração de uma nova estratégia para lidar com uma série de riscos internacionais associados à saúde pública, dentre eles as DIEs: a "global health security". Consolidada na resolução "Global health security: epidemic alert and response" em 2001 (WORLD HEALTH ORGANIZATION, 2001b), essa estratégia contribuiu para alterar como a comunidade internacional percebia os riscos colocados pelas DIEs (YOUDE, 2011), ressaltando a necessidade de instaurar um sistema de vigilância e resposta às epidemias como forma de conter a propagação internacional de doenças e garantir a segurança sanitária.

Para tanto, a "global health security" prevê o estabelecimento de parcerias globais na estruturação de um sistema global de alerta e resposta a esses riscos. Seus objetivos são: (1) a contenção dos riscos à saúde pública já conhecidos; (2) a detecção e resposta às emergências causadas por circunstâncias inesperadas ou desconhecidas; e, (3) o fortalecimento da infraestruturas nacionais de vigilância e controle epidemiológico (HARDIMAN, 2003, p. 209). Conforme demonstra Aginam (2006), esses três objetivos estão diretamente ligados com as atividades que viriam a ser determinadas pelo RSI 2005.

Nesse sentido, a elaboração da estratégia de "global health security" pela OMS pode ser interpretada como parte de um esforço de securitização das doenças infecciosas. Segundo o prisma da abordagem securitizadora discutida anteriormente, essa estratégia procuraria destacar as DIs como um tema de segurança internacional com forma de chamar a atenção para a importância e urgência desse tema.

Por isso, a estratégia "global health security" é fundamental para compreender o desenvolvimento da governança internacional das DIEs a partir da década e 1990, pois ela responde aos problemas e limitações do RSI 1969, oferecendo o lastro para a sua revisão. A "global health security" elucida, assim, a transformação do regime de controle de poucas doenças infecciosas no RSI 1969 num regime abrangente e mais sofisticado de segurança da saúde pública - que abarca também as DIEs - estruturado pelo RSI 2005. Como será analisado na próxima sessão, a aprovação da versão revisada do regulamento consolida, institucionaliza e contempla os três objetivos da "global health security" com o dispositivo legal adequado. 


\subsection{Regulamento Sanitário Internacional (2005)}

Após 10 anos de revisão, o novo Regulamento foi aprovado pela Assembleia Mundial da Saúde em 23 de maio de 2005 (WORLD HEALTH ORGANIZATION, 2005) e entrou em vigor em 15 de junho de 2007. O novo texto estipula um novo mandato a ser desempenhado pelos Estados-parte e pela OMS na governança de uma diversidade de eventos que são riscos à saúde pública internacional, dentre os quais está incluído o surgimento de DIEs.

O objetivo do RSI 2005 é

\footnotetext{
prevenir, proteger, controlar e dar uma resposta de saúde pública contra a propagação internacional de doenças, de maneiras proporcionais e restritas aos riscos para a saúde pública, e que evitem interferências desnecessárias com o tráfego e o comércio internacionais (WORLD HEALTH ORGANIZATION, 2006, p.15).
}

Segundo Youde (2011), o novo Regulamento tem o mesmo propósito do anterior, porém seus métodos são bastante distintos. Em contraste com a edição anterior, essas diferenças são ressaltadas no escopo e nas formas de implementação desse tratado. Enquanto o RSI 1969 objetivava "garantir a máxima segurança contra a propagação de doenças infecciosas", o novo texto expande essa determinação discriminando as atividades de prevenção, proteção, controle e respostas de saúde pública como os meios apropriados de conter a propagação de internacional de doenças. Nesse sentido, esse novo objetivo ajuda a circunscrever o Regulamento na área da saúde pública. Por isso, como será analisado adiante, o RSI 2005 traz disposições sobre capacidades nacionais e procedimentos de saúde pública mais consistentes e em maior detalhamento do que sua versão anterior que se limitava à infraestrutura sanitária em pontos de entrada.

\subsubsection{Componentes substantivos no RSI 2005}

Os componentes substantivos dispostos pelo RSI 2005 na configuração do regime podem ser agrupados em duas categorias: regras sobre a) gestão de informações epidemiológicas; e, b) medidas de saúde e capacidades nacionais. 
a) Gestão de informações epidemiológicas

No âmbito das regras sobre a gestão de informações epidemiológicas, o RSI 2005 traz duas inovações em comparação com sua versão anterior. Essas inovações ampliam a cobertura e implementação do regime em dois âmbitos: quanto aos fenômenos de saúde pública que são objeto do tratado; e, quanto a permissão do uso de outras fontes de informação.

O RSI 2005 obriga todos os Estados-parte a avaliar e notificar a OMS todos os eventos de saúde pública que possam ser de importância internacional. Isso significa que, diferentemente da versão anterior, o Regulamento não se restringe a apenas três doenças. As obrigações colocadas pelo novo Regulamento não se limitam a nenhuma doença ou a modos de transmissão específicos (como, por exemplo, certos vetores), mas referem-se a "doenças ou condições médicas, independente de origem ou fonte, que representam ou poderiam causar dano a humanos" (WORLD HEALTH ORGANIZATION, 2006, p.5).

A mais evidente vulnerabilidade do RSI 1969 estava na limitação de seu escopo, fazendo com que o regime de regras estipulado por esse tratado fosse aplicado apenas para casos de cólera, febre amarela e peste (PLOTKIN; KIMBALL, 1997, p.3). Essa restrição levou à ineficácia da norma e foi um dos principais pontos de discussão durante sua revisão (FIDLER, 1997b, p.61) em que percebeu-se que o novo Regulamento deveria cobrir uma grande variedade de riscos à saúde pública de propagação internacional. Esses riscos seriam os causados pelas doenças infecciosas de ocorrência natural ou intencional, cujas causas sejam conhecidas ou não; e também pelas doenças não-comunicáveis, fruto da liberação, acidental ou intencional, de agentes químicos e radiológicos.

$\mathrm{Na}$ literatura especializada é consenso que o risco colocado pelas DIEs foi fator importante na revisão do RSI (WORLD HEALTH ORGANIZATION, 2002). Segundo Katz e Fischer (2010), na década de 1990 a comunidade internacional reconheceu a crescente risco das DIEs para a saúde das populações. O novo tratado deveria não só abordar outras doenças infecciosas, mas também ser flexível o suficiente para prevenir e responder aos riscos microbianos em constante mutação. Tigerstrom (2005) argumenta que a epidemia mundial de SARS em 2003 comprovou essa ameaça e chamou a atenção da comunidade internacional para a inadequação do RSI, ressaltando a necessidade de ampliar o escopo de aplicabilidade do tratado.

Dessa forma, ficou clara a necessidade de garantir que novo Regulamento instaurasse um regime abrangente que orientasse Estados e instituições internacionais a lidar contra uma 
ampla gama de fenômenos que ofereçam risco à saúde pública. Fidler e Gostin (2006, p.87) argumentam que o fato de o RSI 2005 abordar "todos os riscos" $" 53$ representa uma mudança na estratégia do regime. Enquanto a mínima interferência no comércio internacional orientava as normas no RSI 1969, os riscos à saúde humana definem o escopo na versão revisada.

A heterogeneidade de fenômenos que podem constituir riscos à saúde humana constituiu um desafio para a definição da cobertura do tratado. Para equacionar esse problema e definir o objeto do tratado, foi introduzido o conceito de "emergência de saúde pública de importância internacional" (ESPII). Segundo o RSI 2005, são "eventos extraordinários que [...] constituem um risco para a saúde pública de outros Estados, devido à propagação internacional de doença e [que] potencialmente exigem uma resposta internacional coordenada" (WORLD HEALTH ORGANIZATION, 2006, p.14).

Para auxiliar os Estados a identificarem eventos que podem corresponder a esse tipo, o RSI 2005 dispõe de um instrumento decisório. Essa peça será analisada adiante e sua importância será discutida na sessão que aborda os componentes processuais desse regime.

Outra inovação importante contida no RSI 2005 quanto à gestão de informações epidemiológicas é a autorização da OMS a levar em consideração fontes não oficiais (WORLD HEALTH ORGANIZATION, 2006, p.18). Segundo o artigo 9 do tratado,

a OMS pode levar em conta informes de outras fontes, além das notificações ou consultas, e avaliará tais informes de acordo com os princípios epidemiológicos estabelecidos, transmitindo a seguir informações acerca do evento ao Estado Parte em cujo território supostamente está ocorrendo o evento.

Regulamentar o uso de fontes não oficiais pela OMS é um avanço em relação a versão anterior do RSI em pelo menos dois sentidos. Primeiramente, o artigo 9 corrobora e legitima o papel das redes de monitoramento - como, por exemplo, a GOARN - oficializando a relação entre elas e a OMS para a gestão das informações epidemiológicas. Essa inovação consolida um movimento de reorganização das estruturas de governança dessa agenda, paralelo ao RSI 1969, que vinha se fortalecendo desde a década de 1990. A GOARN, por exemplo, provou ser um ator importante na governança das DIEs ao desempenhar um papel fundamental durante a epidemia de SARS, em 2003.

Foi por meio dessa rede que a OMS recebeu as primeiras informações sobre o surgimento de uma doença infecciosa, até então desconhecida, na China, em meados de novembro de 2002 - cerca de três meses antes da notificação oficial do governo chinês sobre a

\footnotetext{
${ }^{53}$ No original em inglês, "all-risk approach".
} 
epidemia (FIDLER, 2003b). Durante a epidemia de SARS, o GOARN foi o canal pelo qual a OMS conseguiu monitorar os avanços da doença em todo o mundo (KNOBLER et al., 2004). Nesse processo, a formalização da GOARN no início da década de 2000, bem como o papel desempenhado por essa rede na epidemia de SARS em 2003 (DAVIES, 2008; HEYMANN, 2009), advoga em favor da inclusão desses atores no framework legal desse regime.

Além das redes de monitoramento, o novo regulamento enseja a participação na vigilância epidemiológica de clinicas médicas locais, laboratórios, veículos da mídia, lideranças comunitárias, organizações de classe e indivíduos. Esses atores podem estar mais bem posicionados do que as autoridades sanitárias para identificar um risco à saúde pública de propagação internacional com maior celeridade. Ao reduzirem a janela temporal entre o surgimento de uma nova doença e sua detecção, eles contribuem para a eficiência do regime (YOUDE, 2011; BROWN; CETRON, 2012).

Em segundo lugar, essa nova norma também altera o papel dos Estados na governança desses riscos. A partir do RSI 2005, os países não mais controlam o fluxo das informações que chega à OMS (BROWN; CETRON, 2012). Dessa forma, essa nova disposição reduz os incentivos para que os Estados-parte não cumpram as obrigações de notificação. Ao facilitarem o intercâmbio de informações sobre infecções acontecendo em tempo real em praticamente todo o mundo, as redes de vigilância epidemiológica colocam os Estados em uma posição em que esses não podem mais ignorar ou negar declarações sobre surgimento de doenças dentro de suas fronteiras.

De posse dessas informações epidemiológicas, o RSI 2005 estipula que cabe ao Diretor-geral da OMS determinar se um evento notificado por um Estado-parte - ou via outras fontes de informação não-oficiais com sua posterior verificação - constitui uma ESPII. Essa prerrogativa será discutida na sessão sobre os componentes processuais desse regime, pois a declaração de uma ESPII decorre de um processo decisório previsto no Regulamento.

b) Medidas de saúde e capacidades nacionais

O outro grupo de regras estipuladas pelo RSI 2005 diz respeito aos procedimentos e às capacidades básicas que os Estados-parte devem implementar e manter para garantir o funcionamento do regime.

Da mesma forma que sua versão anterior, o RSI 2005 discrimina quais são as medidas de saúde que devem ser aplicadas a veículos, cargas e pessoas em trânsito internacional. O Regulamento define "medidas de saúde" como "procedimentos realizados para evitar a 
propagação de doenças ou contaminação [sendo que essas] não incluem medidas de 'law enforcement' ou de segurança" (WORLD HEALTH ORGANIZATION, 2006, p.13). Tal definição explicita a preocupação de restringir o escopo do tratado à área da saúde pública como forma de evitar o uso da força e de outras medidas extraordinárias no controle dos riscos em questão.

O RSI 2005 atualiza a versão anterior no que diz respeito às medidas aplicáveis aos veículos e suas cargas. Ambos estipulam como devem ser tratadas na chegada e partida embarcações suspeitas de contaminação, ou provenientes de uma área onde há uma infecção confirmada, tratamento de cargas, realização de inspeções sanitárias, por exemplo. Essas medidas estão descritas com detalhamento técnico nos anexos 4 e 5 do RSI 2005.

A inovação mais significativa a respeito das medidas sanitárias estipuladas no novo Regulamento refere-se ao tratamento de viajantes. No capítulo dedicado a esse assunto no RSI 2005, destaca-se que cabe aos Estados-parte tratar os viajantes respeitando a sua "dignidade, direitos humanos e liberdades fundamentais, e minimizando qualquer desconforto ou aflição" (Artigo 32). Essa colocação decorre do artigo 3 do RSI 2005 que impõe o respeito aos direitos humanos como um princípio geral para a implementação do tratado (TUCKER, 2005). Essa diretriz é observada em pelo menos quatro regras a respeito do tratamento das pessoas em trânsito internacional num contexto de ESPII: o uso das medidas menos invasivas e intrusivas disponíveis para garantir o nível apropriado de proteção à saúde pública (Artigo 23.1); a necessidade do consentimento prévio para a realização de exames médicos, vacinação e outras medidas (Artigo 25.3 e 25.4); proteção das informações de saúde dos indivíduos (Artigo 45); e, autorizações e restrições de cobranças relativas às medidas realizadas (Artigos 40) (PLOTKIN, 2007).

Ainda que essas disposições mostrem um reconhecimento mais explícito dos direitos humanos no RSI 2005, não há menções a outros tratados, declarações ou dispositivos internacionais de direitos humanos e alguns analistas têm levantado críticas sobre esse aspecto. Plotkin (2007) preocupa-se com a definição pragmática de quem estariam sujeitos à norma, visto que as definições de viajantes e viajantes internacionais abrem espaço para uma dúbia interpretação ${ }^{54}$. Ainda que estejam assegurados os direitos humanos aos viajantes na aplicação das medidas de saúde, Youde (2011, p.814) comenta sobre as possíveis violações devido às estratégias de "vigilância biopolítica" sobre as quais o regulamento se baseia.

\footnotetext{
${ }^{54}$ Essa dúbia interpretação ocorre devido ao uso inconsistente do conceito de "viajante" em alguns artigos do tratado e de "viajante internacional", em outros. Essa inconsistência complicaria, segundo Plotkin (2007), a aplicação do Regulamento sobre, por exemplo, um grupo contendo tanto viajantes internacionais e quanto nacionais, ou, num segundo caso, sobre indivíduos transitando nas redondezas dos pontos de entrada.
} 
A percepção de que as capacidades nacionais de monitoramento e resposta são fundametais para a governança das DIEs - bem como de outros eventos compreendidos na definição de ESPII - precede o próprio RSI 2005. Essa noção faz parte da estratégia "global health security" que aponta para a necessidade de se estruturar um sistema global de vigilância e resposta epidemiológica para lidar com esses riscos. Nesse sentido, o RSI 2005 consolida essa tendência ao oficializar a obrigação legal dos Estados para com essa estratégia, funcionando como um framework normativo para a implantação e manutenção de uma infraestrutura básica nacional capaz de desempenhar essas atividades (WORLD HEALTH ORGANIZATION, 2010, p.5).

Segundo Fidler (2003a), isso evidencia a "verticalização" da governança das DIs. Ao descrever de que forma os Estados devem se organizar em âmbito interno para cumprir as obrigações do regime, o RSI 2005 reconhece que as DIs são ameaças que "perpassam" Estados, em detrimento do entendimento dessas como ameaças exógenas. Nesse sentido, a estratégia vertical da governança objetiva reduzir a propagação das doenças infecciosas dentro dos Estados, ao invés de apenas dedicar-se a gerir o tráfego internacional dos micróbios pelas vias comerciais e turísticas.

Por isso, determinar como cada país deve se organizar para detectar e reagir às ESPII em seu território é um avanço nesse regime. Esse avanço fortalece a governança das DIEs na medida em que, segundo argumenta Heymann (2009), a estruturação de um sistema de vigilância e resposta altamente sensível nos Estados é a mais importante defesa contra a sua propagação internacional. Na mesma linha, Hardiman (2012) defende que sistemas nacionais de saúde efetivos são as bases para a segurança da saúde global pois reúnem as ferramentas para prevenir que muitos eventos de saúde pública se tornem riscos internacionais. Por isso, dispor de uma infraestrutura básica capaz de desempenhar funções de detecção e resposta às DIEs é uma forma preparo para emergências internacionais dessa natureza.

O fortalecimento das capacidades básicas de saúde pública é parte importante do novo Regulamento. Enquanto o RSI 1969 limitava-se a abordar a organização dos pontos de entrada, o RSI 2005 especifica a infraestrutura de saúde pública nacional necessária que os Estados-parte tem obrigação de implementar e manter. Sobre isso, o artigo 13 do tratado coloca que os "Estados-parte devem desenvolver e manter [...] a capacidade de responder prontamente e efetivamente aos riscos e emergências de saúde pública de importância

\footnotetext{
55 "threats within states", no original
} 
internacional conforme dispostas no Anexo I" (WORLD HEALTH ORGANIZATION, 2006, p.20).

Em duas sessões, o anexo I aborda como deve ser organizada a infraestrutura nos pontos de entrada e os requisitos mínimos para vigilância e resposta da saúde pública dos países para lidar com os eventos cobertos pelo RSI 2005. Nos aeroportos designados, portos e pontos de entrada terrestres, os países são obrigados a instalar capacidade de diagnóstico, viabilizar o acesso e trabalho de equipes médicas, prover pessoal qualificado para inspecionar veículos e examinar viajantes, garantir a salubridade das instalações e delimitar zonas de entrevista e avaliação de pessoas sob observação e quarentena. Tais determinações não diferem substancialmente daquelas já contidas na versão anterior do Regulamento.

No que diz respeito às capacidades necessárias, o RSI 2005 inova ao discriminar os requisitos mínimos necessários para o funcionamento da vigilância epidemiológica e resposta da saúde pública que devem ser observados pelos Estados-parte. Sobre esse aspecto, a primeira sessão do anexo I especifica quais atividades os países devem desempenhar dentro de seus territórios nos níveis nacional, intermediário e local.

No nível nacional, os Estados devem manter capacidades para realização de dois tipos de atividades: primeiro, avaliação e notificação; e, segundo, respostas de saúde pública. No primeiro deles, as autoridades nacionais dos países devem ser capazes de avaliar todos os relatórios de eventos urgentes dentro de 48 horas e, se for o caso, notificar à OMS.

Sobre as respostas de saúde pública, o RSI 2005 determina que, no nível nacional, os países devem ter condições de determinar as medidas de contenção necessárias para prevenir a propagação nacional e internacional do risco em questão; prover apoio às investigações locais e às análises laboratoriais; garantir a comunicação para a operação conjunta entre diversas autoridades sanitárias e entre hospitais, aeroportos, clínicas, laboratórios, entre outros; e, estabelecer, operar e manter um plano de emergência para a resposta em saúde pública.

No nível intermediário, as capacidades são necessárias para avaliação, confirmação e posterior notificação às autoridades nacionais de eventos relatados pelas autoridades locais, além de auxiliar na implementação de medidas adicionais.

Por fim, no nível local, os Estados devem garantir o funcionamento das capacidades para detecção de eventos envolvendo doenças ou mortes de maior ocorrência do que o esperado, bem como implementar medidas de controle preliminares para contenção do risco. Ademais, cabe a esse nível a função de repassar às autoridades superiores, todas as informações pertinentes relativas aos eventos no âmbito do Regulamento como, por exemplo, 
descrições clínicas, resultados laboratoriais, número de casos de mortes, condições que afetam a propagação e as mediadas empregadas para sua contenção.

Segundo Brown e Cetron (2012), o processo de implementação das capacidades nacionais, desde a entrada em vigor do RSI 2005, está atrasado. Muitos países em desenvolvimento carecem de recursos para investir nas atividades requeridas no tratado. $\mathrm{Ou}$ então, quando esses recursos estão disponíveis mas são escassos, governos preferem aplicálos não na infraestrutura determinada pelo RSI, mas sim em programas de combate a problemas de saúde pública mais graves ou mais imediatos que afetem suas populações, como controle à tuberculose, HIV/AIDS e malária (MCDOUGALL et al., 2008). Segundo Brown e Cetron (2012), a crise econômica global desde 2008 também é responsável pela redução dos investimentos na implementação das capacidades básicas.

A implementação das capacidades nacionais pode se tornar um obstáculo para o envolvimento dos países no regime estipulado pelo RSI 2005. Ao conferir à OMS influência direta sobre como os sistemas de vigilância e resposta epidemiológica nacionais devem ser organizados e implementados, o RSI 2005 favorece o aumento da supervisão e interferência internacional no âmbito politico doméstico (YOUDE, 2011). Países que, seja por escassez de recursos ou incapacidades técnicas, não conseguem implantar tais capacidades estão em desacordo com o Regulamento e, portanto, infringem a lei internacional.

\subsubsection{Componentes processuais no RSI 2005}

Para auxiliar os Estados a identificarem eventos que podem corresponder a esse tipo, o RSI 2005 dispõe de um instrumento decisório (ANNEX II). A ferramenta é um protocolo que reúne uma série de perguntas sobre as características do fenômeno em questão. 
Figura 4 - Instrumento de decisão para avaliação e notificação dos eventos que possam constituir emergência de saúde pública de importância internacional.

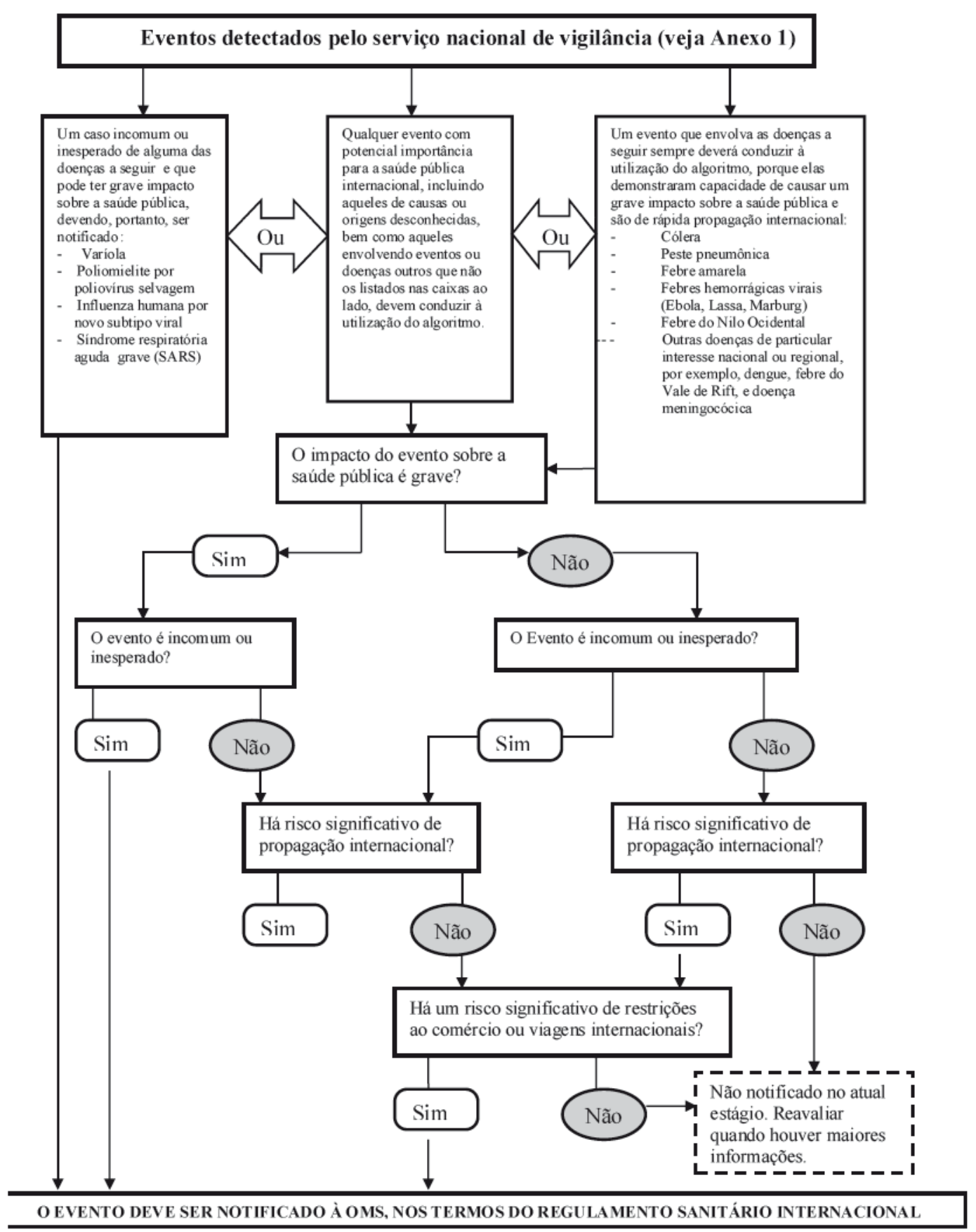

Fonte: ANVISA. Regulamento Sanitário Internacional. Brasília: Anvisa, 2007.

A adoção desse instrumento decisório é um avanço do regime instaurado pelo RSI 2005, pois contribuiu para sua eficácia e eficiência ao padronizar os procedimentos realizados pelos Estados antes de notificar. Essa padronização permite que autoridades sanitárias nacionais ajam com maior segurança ao lidar com fenômenos dessa natureza, minorando as ambiguidades no processo de avaliação do risco de propagação internacional (ANDRUS et 
al., 2010) e esclarecendo as condições necessárias para notificar à OMS. Em pesquisa realizada em 2012, Anema et al. (2012) demonstraram que, dentre as autoridades encarregadas $^{56}$ de utilizar o anexo II que foram entrevistadas, 95\% declararam que o protocolo facilita decisões sobre a "notificabilidade" de eventos à OMS; 88\% consideram ter um bom conhecimento dessa ferramenta; $77 \%$ adotam o anexo II para avaliar possíveis ESPII; e, 76\% assumiram que seus países contam com provisões legais para a sua utilização.

O instrumento ainda possibilita a expansão da cobertura do tratado, auxiliando na compreensão de quais eventos, dentre os diversos riscos à saúde pública, podem ser de importância internacional e, portanto, devem ser notificados. Segundo Fidler e Gostin (2006), esse protocolo foi desenvolvido com o objetivo específico de fazer com que as DIEs fossem cobertas pelo RSI 2005. Viabilizando a notificação de um evento incomum ou inesperado que apresente risco de propagação internacional, o instrumento abre margem para a notificação de doenças infecciosas desconhecidas.

A importância disso é que, nesse caso, dispensa-se a necessidade de um diagnóstico. A identificação de evento de saúde pública com risco de propagação internacional, mesmo que ainda se desconheça sua causa, já é suficiente para que o regime entre em operação. Ademais, o instrumento de decisão também discrimina as doenças infecciosas já conhecidas que devem ser notificadas imediatamente. Essa lista inclui varíola, SARS e novas variações de influenza.

Além do instrumento de decisão para eventos que possam constituir uma ESPII, o RSI 2005 determina novos procedimentos que auxiliam na tomada de decisões para o funcionamento do regime. Esses mecanismos são resultados da articulação entre o Diretorgeral da OMS e dois órgãos criados pelo RSI 2005: o Comitê de Emergência e o Comitê de Revisão.

O Diretor-geral da OMS pode convocar o Comitê de Emergência ${ }^{57}$ para lhe fornecer informações que lhe auxiliem na tomada de decisões em relação a três matérias: a determinação de se um evento constitui uma ESPII; a terminação de uma ESPII previamente instituída; e, a publicação, modificação, extensão ou revogação de recomendações temporárias. Dessa forma, o Comitê de Emergência atua como uma espécie de consultoria especializada, subsidiando as decisões do Diretor-geral.

\footnotetext{
${ }^{56}$ As autoridades entrevistadas nessa pesquisa são os Pontos Focais Nacionais cuja função será discutida oportunamente nesse capítulo.

${ }^{57}$ O RSI 2005 também determina que o Comitê de Emergência seja composto por especialistas convocados do “Cadastro de Peritos do RSI". Esse, por sua vez, reúne peritos em todos os campos de especialização pertinentes, nomeados pelo Diretor-geral da OMS de acordo com o Regulamento da OMS para Painéis e Comitês assessores de Peritos, além da indicação dos Estados-parte e de organismos internacionais pertinentes (WOLRD HEALTH ORGANIZATION, 2006, p.38).
} 
A partir das notificações que o secretariado da OMS recebe de suas fontes, o poder de determinar quais delas constituem uma ESPII cabe apenas ao Diretor-geral. Para tanto, o RSI 2005 estipula que ele deve considerar as informações providas pelo Estado-parte afetado, o instrumento de decisão no anexo II e a opinião do Comitê de Emergência, apreciando também princípios e evidencias científicas, avaliando o risco à saúde humana, de propagação e de interferência no comércio e tráfego internacional. Os mesmos critérios devem ser avaliados para a terminação de uma ESPII.

A primeira vez em que foi convocado um Comitê de Emergência foi em 25 de abril de 2009, para analisar o risco colocado pelo aumento dos casos de influenza no mundo. Ainda nessa mesma data, após ser aconselhado por esse órgão, o Diretor-geral da OMS declarou publicamente que a epidemia do vírus da Influenza A (H1N1) constituía uma ESPII - agindo em conformidade com os procedimentos previstos no RSI 2005.

Após declarar que determinado evento constitui uma ESPII, o Diretor-geral, também assistido pelo Comitê de Emergência, pode emitir recomendações temporárias aos Estadosparte. Essas recomendações orientam os países quanto às

\footnotetext{
medidas de saúde que devem ser implementadas pelo Estado-parte experienciando a ESPII, ou por outros Estados-parte, em relação a pessoas, bagagens, cargas, containers, veículos, bens e/ou correspondências para prevenir ou reduzir a propagação internacional de doenças e evitar interferência desnecessária com o tráfego internacional (WOLRD HEALTH ORGANIZATION, 2006, p.22)
}

Nesse sentido, as recomendações temporárias são produtos do funcionamento do regime, buscando interferir no comportamento dos atores - Estados, organizações, indivíduos, etc. - durante uma ESPII propondo medidas para conter a propagação de doenças. Visto que o RSI 1969 não dispunha de elemento semelhante, a possibilidade de emitir esse tipo de recomendação é uma novidade que aprimora o funcionamento do regime na medida em que regulariza e normatiza como a OMS se relaciona com os Estados-parte num contexto emergencial.

A inclusão do poder de emitir recomendações no novo regulamento decorre da experiência que a OMS teve durante e epidemia de SARS em 2003. Naquela ocasião, preocupada com a rápida propagação do vírus, a organização publicou diversas alertas globais e recomendações de viagens causando prejuízos econômicos aos países afetados. Segundo explica Fidler (2004), a atuação da OMS nessa questão foi radical por três motivos. Primeiramente, nem a Carta da OMS nem o RSI 1969 em vigor à época autorizavam a OMS a fazer recomendações sobre viagens às áreas afetadas. Tal autoridade nem mesmo constava nas 
sugestões encaminhadas pelo secretariado do órgão para a revisão do RSI. Em segundo lugar, a OMS agiu independentemente e contra vários de seus Estados-membros, causando desgaste político e danos econômicos. Por último, as recomendações sobre viagens foram feitas diretamente para "viajantes", e não para os seus Estados-membros como deveria ter sido feito de acordo com os anais de procedimentos da instituição.

Durante a pandemia de H1N1 em 2009, a OMS emitiu recomendações temporárias de que não fossem impostas quaisquer restrições ao comércio e tráfego internacionais. Ademais, essas recomendações também traziam as medidas que poderiam ser adotadas pelos Estadosparte para prevenir a propagação da doença, evitando consequências econômicas e sociais desnecessárias. Ainda assim observou-se que diversos países tomaram unilateralmente medidas excessivas sem o consentimento da OMS e desconsiderando, em alguns casos, princípios científicos e respeito aos direitos humanos. China e Singapura colocaram em quarentena alguns viajantes oriundos das regiões afetadas, independentemente se haviam ou não sido expostos ao vírus (KATZ, 2009). Autoridades egípcias ordenaram o sacrifício de 250.000 porcos sem que houvesse casos da doença no país ou qualquer suspeita de contaminação de suínos no mundo (ABC, 2009). Além disso, um total de 20 países baniram importação de carne de porco e derivados do México, EUA e Canadá, a despeito da declaração conjunta da OMS, FAO, Organização da Saúde Animal e da Organização Mundial do Comércio de que carne suína não era fontes de infecção da doença (LYNN, 2009).

O papel do Comitê de Revisão é o de acompanhar a implementação do tratado e avaliar o funcionamento do regime. Dessa forma, o Comitê de Revisão auxilia o Diretor-geral propondo emendas ao tratado, subsidiando-o com informações sobre recomendações permanentes e sobre outros assuntos relativos ao Regulamento (Artigo 50). Para acompanhar a implementação das capacidades de saúde pelos Estados-parte, conforme consta no anexo I do RSI 2005, o comitê assessora o Diretor-geral na emissão de recomendações permanentes que são orientações

de natureza não-vinculativa [...] com referência a riscos para a saúde pública específicos existentes, e relativa às medidas de saúde apropriadas, de aplicação rotineira ou periódica, necessárias a prevenir ou reduzir a propagação internacional de doenças e minimizar a interferência com o tráfego internacional (ANVISA, 2007, p.17).

Diferentemente das recomendações temporárias, as recomendações permanentes podem ser emitidas independentemente da declaração de uma ESPII. Ao orientarem os Estados-parte na aplicação de medidas e implantação de infraestrutura para conter os riscos 
em questão, as recomendações permanentes funcionam como incentivos para que os atores observem as normas do regime ${ }^{58}$, adequando capacidades de saúde em seus territórios às obrigações trazidas pelo RSI 2005.

\subsubsection{Componentes de implementação no RSI 2005}

Os componentes de implementação desse regime correspondem aos atores que aplicam as normas, garantem a sua operação, e/ou criam incentivos para seu funcionamento adequado. A partir do RSI 2005, é possível identificar os atores que se enquadram nessa definição, conforme disposto no seguinte quadro:

\footnotetext{
${ }^{58}$ Em relação ao trâmite de avaliação e emissão das recomendações permanentes, considera-se que o Comitê de Revisão e o Diretor-geral são considerados mecanismos de tomada de decisões - e, portanto, se enquadram na definição de componentes processuais do regime. Por outro lado, esses atores também podem ser considerados componentes de implementação, visto que as recomendações permanentes colaboram e coagem os atores com a observância às normas do regime.
} 
Quadro 2 - Componentes de implementação: principais atores e suas atribuições no regime

Avaliar os eventos ocorrendo no território com base no Anexo II (art.6);

Verificar, a pedido da OMS, a ocorrência de casos que possam constituir uma ESPII a partir de casos oriundos de outras fontes (art.10);

Implantar e manter as capacidades básicas para o funcionamento das

Geral atividades de detecção, monitoramento, controle, prevenção e resposta aos riscos à saúde pública em seus territórios (art.13);

Aplicar as medidas de saúde requeridas aos veículos, cargas e pessoas em tréfego internacional (Parte V);

Tratar viajantes com respeito aos direitos humanos (art.32).
Auxiliar os Estados na implementação das medidas e capacidades básicas, publicando diretrizes e recomendações (art.5);

Enviar aos Estados e as organizações internacionais pertinentes as informações recebidas sobre eventos que podem constituir ESPII (art.12);

Geral Colaborar, a pedido dos Estados, nas respostas aos riscos à saúde

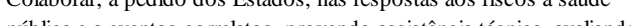
pública e a eventos correlatos, provendo assistência técnica, avaliando

Cooperar e coordenar atividades com outras organizações internacion para a implementação do RSI (art. 14).

\author{
Redes de Reunir e disponibilizar informações sobre \\ monitoramento, a ocorrência de casos que podem \\ plataformas de constituir uma ESPII: \\ informaç̃o em \\ saúde, hospitais, Compartihar com Estados, organismos \\ veículos de internacionais e outros atores \\ comunicação, informaç̃es sobre ESPII; \\ laboratórios, \\ mobilização de recursos
}

internacionais, etc. monitoramento das resposta às ESPII.

Comunicação com a OMS, em especial com respeito notificação de

Ponto Focal possíveis ESPII (art.4);

Pron Focal p

Disseminação de informações no país para estruturas de vigialância e

o RSI (PFN) notificação, pontos de fronteira, serviços de saúde pública, clínicas e hospitais e outros departamentos governamentais.

Determinar se um evento consitui uma ESPII (art.12);

Diretor-geral Emitir recomendações temporárias e permantes, com consultoria dos Comitês de Emergência e Revisão do RSI.

$$
\text { Autoridades sanitárias }
$$

\begin{tabular}{|c|c|c|c|}
\hline & Autoridades sanitárias & & \\
\hline Nível nacional & $\begin{array}{l}\text { Avaliar e notificar a ocorrêcnia de caos que possam constituir uma ESPII; } \\
\text { Notificar à OMS via PFN; }\end{array}$ & $\begin{array}{l}\text { Ponto de } \\
\text { Contato } \\
\text { para o RSI }\end{array}$ & $\begin{array}{l}\text { Comunicação com o Estado-parte, em especial com respeito notificação } \\
\text { de possíveis ESPII (art.4). }\end{array}$ \\
\hline & Responder às ESPII: contenção e controle. & & \\
\hline $\begin{array}{c}\text { Nível } \\
\text { intermediário }\end{array}$ & $\begin{array}{l}\text { Investigar os eventos e confirmar as informações reportadas pelo nível } \\
\text { local; } \\
\text { Avaliar eventos notificccados e reportar todas as informações necessárias } \\
\text { ao nível nacional. }\end{array}$ & $\begin{array}{l}\text { Comitê de } \\
\text { Emergência }\end{array}$ & $\begin{array}{l}\text { Aconselhar o Diretor-geral acerca de (art.48): } \\
\text {-Determinação ou término de uma ESPII; } \\
\text {-Emissão de recomendaçôes temporárias. }\end{array}$ \\
\hline $\begin{array}{l}\text { Nível } \\
\text { local }\end{array}$ & $\begin{array}{l}\text { Medidas de controle preliminares; } \\
\text { Reportar todas as informações pertinentes às autoridades de saúde } \\
\text { apropriadas. }\end{array}$ & $\begin{array}{c}\text { Comitê de } \\
\text { Revisão }\end{array}$ & $\begin{array}{l}\text { Aconselhar o Diretor-geral acerca de (art.50): } \\
\text {-Incluãão de emendas ao tratado; } \\
\text {-Avaliar o andamento da implementação do regime; } \\
\text {-Emissão de recomendaçôes permanentes. }\end{array}$ \\
\hline
\end{tabular}

Fontes: ANVISA. Regulamento Sanitário Internacional. Brasília: Anvisa, 2007.; BAKER, Michael G.; FIDLER, David. Global public health surveillance under the new International Health Regulations. Emerging Infectious Diseases, v.12, n.7, 2006. 
A identificação componentes de implementação do RSI 2005 deixa claro que a OMS e os Estados continuam sendo os principais atores desse regime. Essa constatação evidencia que as DIEs são sujeitas a um padrão de governança internacional - mais do que de governança global -, de acordo com a definição de Fidler (2002) discutida no capítulo anterior. Nesse âmbito, a OMS permanece como o ator central no regime instituído pelo RSI 2005. A organização atua estabelecendo padrões internacionais para a segurança da saúde pública global, coordenando os esforços para a contenção dos riscos, mobilizando recursos técnicos, e avaliando o desempenho do regime.

Em relação à vigilância epidemiológica, o tratado transfere poder à organização, ao fazer dessa uma espécie de repositório internacional desse tipo de informação (YOUDE, 2011). Ao seu lado, os Estados-parte também desempenham papel fundamental no regime. Estão sob sua responsabilidade as atividades de monitoramento, compartilhamento de informações e de toda a organização sanitária em seus territórios. A centralidade desses dois tipos de atores configura a governança internacional das DIEs. Ainda que o novo regulamento reconheça a participação de outros atores nesse regime, como, por exemplo, as redes de monitoramento global, sua atuação depende da articulação com os Estados ou com a OMS.

Ainda que os Estados-parte e a OMS ainda sejam os atores centrais na implementação do regime, quando comparado com o RSI 1969, o novo regulamento aprofunda a distribuição de responsabilidades na organização doméstica dos Estados-parte e também institui novas figuras. Desses implementadores, merecem atenção especial os "pontos focais nacionais" (PFNs), autoridades sanitárias nos três níveis domésticos da administração pública e outros atores.

Durante a vigência do RSI 1969, a ausência de um protocolo oficial de comunicação acarretou problemas no relacionamento entre a OMS e os países. Essas dificuldades foram ressaltadas durante o processo de revisão do tratado em que se percebeu a necessidade de reorganizar o fluxo de informações entre a organização e os países, elencando uma nova figura de autoridade com essas funções (WORLD HEALTH ORGANIZATION, 2002).

Dessa forma, o RSI 2005 padroniza e aprimora os protocolos de comunicação entre a OMS e os Estados-parte, centralizando o intercâmbio de informações oficiais na figura do "Ponto Focal Nacional" (PFN). Os PFNs são centros nacionais que se encarregam de todas as comunicações relativas à implementação do RSI, em âmbito doméstico e internacional (HARDIMAN, 2012; TUCKER, 2005). Importantes especialmente nos contextos emergenciais, o PFN deve estar acessível ao "Ponto de Contato da OMS" para contato todos os dias do ano, 24 horas por dia. 
A instauração dessa autoridade foi bem aceita pela comunidade internacional, visto que um ano após a entrada em vigor do RSI 2005, 188 Estados-parte já haviam designado seus PFNs. Nesse sentido, Hardiman (2012) considera que o sucesso no estabelecimento dos PFNs é uma demonstração do compromisso global com a implementação do RSI $2005^{59}$.

No contexto específico da governança das DIEs, a atribuição central dos PFN é a de notificar à OMS o surgimento de uma nova doença, procedimento o qual deve ser realizado de acordo com o Anexo II do RSI 2005. Anema et al. (2012) demonstraram que os PFNs tem um bom conhecimento dessa ferramenta decisória e contam com apoio legal e institucional para essa atividade. A relevância dessas figuras na implementação do regime a partir do RSI 2005 foi posta a prova em 2009 durante a pandemia de H1N1. Hardiman (2012) afirma que o contato entre os PFN e os "Pontos de Contato da OMS" foram peças fundamentais na circulação de informações oficiais sobre a propagação e contenção da doença, conforme o vírus era identificado em todo o mundo, especialmente nos primeiros meses.

Katz e Fischer (2010) afirmam que, durante a pandemia de H1N1 em 2009, as autoridades atuaram rigorosamente conforme o que o RSI 2005 estipulava. Após a primeira notificação feita pelo México, a Organização Pan-americana da Saúde (braço regional da OMS) iniciou consultas com o país. Posteriormente, os PFNs do México e dos EUA continuaram provendo informações sobre casos da doença em seus territórios. Conforme estipulado pelo RSI 2005, o Diretor-geral da OMS consultou ambos os países e declarou a emergência do H1N1 como uma ESPII. Isso aponta para a importância das primeiras notificações de potenciais ESPII feitas pelos PFNs dos EUA e México que posteriormente seriam confirmados como casos da doença (KATZ, 2009). No mais, durante toda a pandemia, os países de todo o mundo relataram diariamente os números de casos suspeitos e confirmados à OMS (KATZ, 2009, p.1167) - o que denota a validade e eficácia dos protocolos de comunicação entre a OMS e os Estados-parte implementados pelos PFNs.

Diferentemente da versão anterior, o RSI 2005 não só detalha quais as capacidades e medidas mínimas que devem ser garantidas e desempenhadas pelos Estados, mas também distribui essas responsabilidades nos três níveis domésticos: nacional, intermediário e local. Dessa forma, conforme disposto no Anexo I, autoridades sanitárias nos três âmbitos da administração pública tem obrigações a cumprir perante o tratado.

\footnotetext{
${ }^{59}$ Segundo Hardiman (2012), apenas um dos Estados-parte do RSI 2005 não estabeleceu um PFN.
} 
Figura 5 - Autoridades implementadoras do RSI 2005 nos âmbitos doméstico e internacional

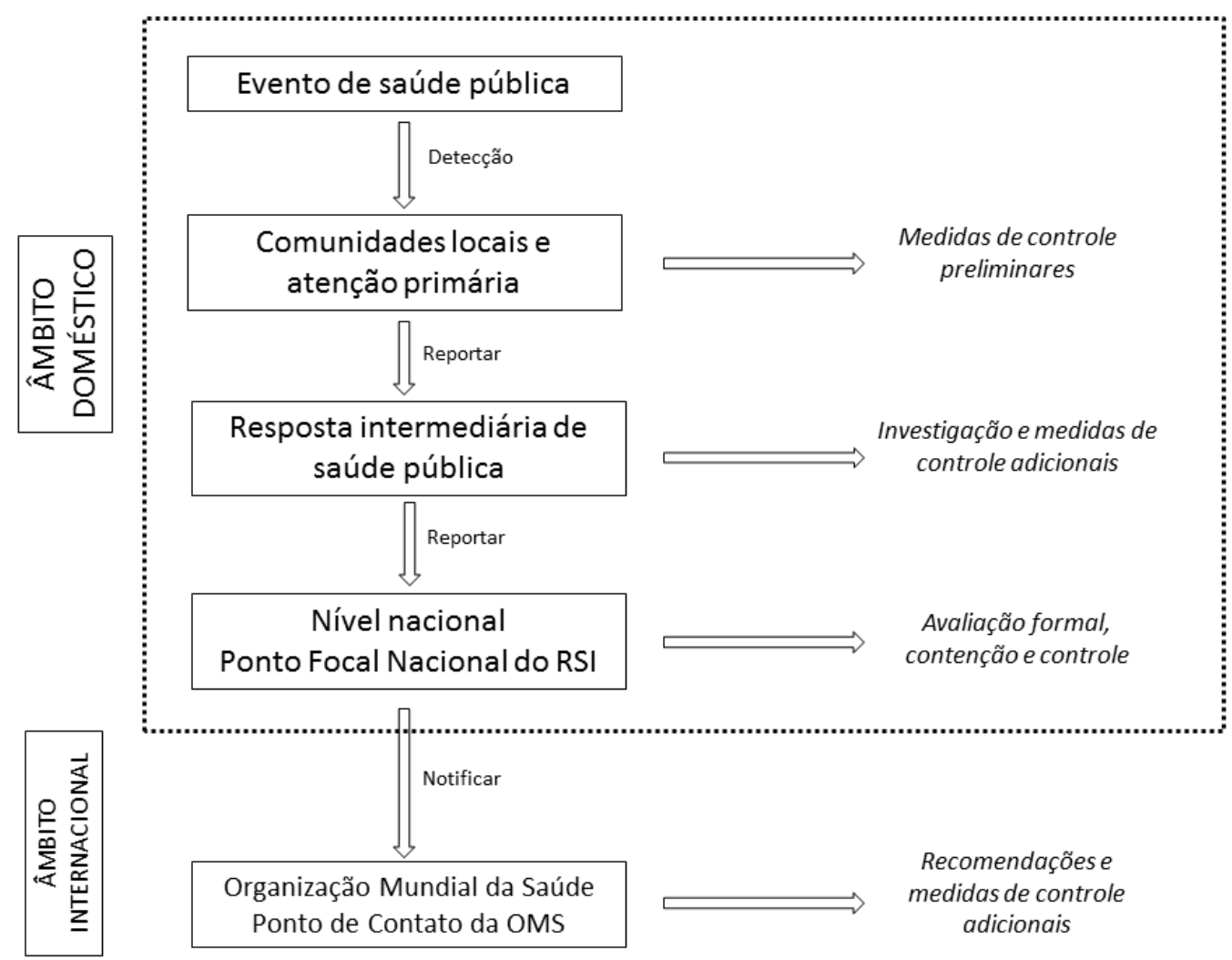

Fonte: BAKER, Michael G.; FIDLER, David. Global public health surveillance under the new International Health Regulations. Emerging Infectious Diseases, v.12, n.7, 2006.

Essa descentralização no contexto político doméstico dessas atribuições ensejadas no RSI 2005 pode constituir um desafio para alguns Estados. Wilson et al. (2008) alertam que diversos países de sistema político federativo podem encontrar dificuldades ao implementar o novo regulamento. Por exemplo, em vários deles a vigilância epidemiológica é uma atribuição exclusiva das administrações intermediárias, e não dos governos nacionais. Ou então, em outros casos, governos regionais podem não compartilhar informações com o governo federal por medo de prejuízos econômicos, ou para evitar intromissões em suas jurisdições. Essas nuances podem dificultar as respostas às emergências de saúde pública, comprometendo a governança das DIEs. Além disso, federações podem ter mais dificuldades em implementar de maneira padronizada em todo seu território as capacidades e medidas de saúde determinadas pelo regulamento. Durante a epidemia de SARS em 2003, por exemplo, o governo do Canadá teve muitas dificuldades em obter informações sobre casos da doença das suas províncias - o que comprometeu, em parte, a resposta à epidemia e, em especial, o repasse dessas informações à OMS (WILSON et al., 2006). 
Ao permitir que a OMS utilize informações provenientes de fontes não-oficiais para verificar a ocorrência de ESPII, o novo regulamento reconhece as contribuições de uma variedade de outros atores nas atividades de vigilância epidemiológica e na gestão de informações. Segundo o disposto no RSI 2005, redes de monitoramento, plataformas de informação de saúde pública, hospitais, veículos de comunicação, laboratórios, clínicas e organismos internacionais participam na implementação do regime.

A importância dessa miríade de atores foi verificada durante a pandemia de H1N1. Segundo Zhang et al. (2013), os investimentos nos sistemas de vigilância e notificação globais - especialmente em redes de laboratórios - foram importantes para a detecção precoce da propagação do vírus. Dessa forma, essas redes tem se tornado as principais fontes de notificações de doenças à OMS, ultrapassando as notificações de fontes oficiais. Conforme aponta Heymann (2006), entre janeiro de 2001 e outubro de 2004, 61\% dos casos de doenças infecciosas foram relatados por instituições não-oficiais por meio dessas redes. Visto que a implementação bem-sucedida do Regulamento depende das atividades de vigilância epidemiológica (YOUDE, 2011), essa inovação favorece a governança das DIEs.

\subsection{Conclusões}

Esse capítulo procurou demonstrar de que forma se desenvolveu a governança internacional das DIEs a partir da análise do principal dispositivo normativo em questão: o Regulamento Sanitário Internacional. Foi discutida a forma com que, apesar da sua inaplicabilidade às DIEs, a ineficácia e limitação do RSI 1969 abriram margem para a ascensão da estratégia de global health security. Essa, por sua vez, serviu de fundamento e orientou a reestruturação do regime com a aprovação do RSI 2005. Com isso, o RSI 2005 consolida uma série de novas estratégias que vinham sendo discutidas e desenvolvidas no bojo da OMS desde a década de 1990 e que compõem o paradigma de global health security.

Para traçar o desenvolvimento da governança das DIEs de maneira detalhada, foi realizada uma comparação sistemática entre os RSI de 1969 e 2005. Os critérios de essa análise foram os componentes dos regimes internacionais: substantivos, processuais e de implementação. Os resultados seguem sintetizados no quadro a seguir: 
Quadro 3 - Síntese da análise dos regimes internacionais por componentes

REGULAMENTO SANITÁRIO INTERNACIONAL (1969)

\section{REGULAMENTO SANITÁRIO} INTERNACIONAL (2005)

\begin{tabular}{|c|c|c|}
\hline & $\begin{array}{l}\text { Escopo limitado a três doenças infecciosas } \\
\text { específicas (febre amarela, peste e cólera). }\end{array}$ & $\begin{array}{l}\text { Agrega diversos tipos de riscos, inclusive as DIEs, } \\
\text { na concepção de "emergências de saúde pública de } \\
\text { importância internacional" (ESPII). }\end{array}$ \\
\hline \multirow{7}{*}{$\begin{array}{l}\text { COMPONENTES } \\
\text { SUBSTANTIVOS }\end{array}$} & & $\begin{array}{l}\text { Estados são obrigados a informar a OMS sobre } \\
\text { casos que possam constituir uma ESPII. }\end{array}$ \\
\hline & $\begin{array}{l}\text { Estados são obrigados a informar a OMS sobre } \\
\text { casos das doenças objeto do tratado. }\end{array}$ & $\begin{array}{l}\text { OMS pode considerar notificações de possíveis } \\
\text { ESPII provenientes de fontes não-oficiais como, por } \\
\text { exemplo, mídia, redes de monitoramento e } \\
\text { organismos não-governamentais. }\end{array}$ \\
\hline & $\begin{array}{l}\text { Estipula "medidas máximas" aplicáveis para evitar } \\
\text { interferências desnecessárias com o comércio e } \\
\text { tráfego internacionais. }\end{array}$ & $\begin{array}{l}\text { Estipula "medidas minímas" aplicáveis para redução } \\
\text { dos riscos à saúde humana evitando interferência } \\
\text { desnecessária no comércio e tráfego internacionais. }\end{array}$ \\
\hline & $\begin{array}{l}\text { Medidas e capacidades de saúde estipuladas são } \\
\text { limitadas às atividades nos pontos de fronteira. }\end{array}$ & $\begin{array}{l}\text { Medidas e capacidades de saúde estipuladas dizem } \\
\text { respeito à organização nacional para conter riscos. }\end{array}$ \\
\hline & $\begin{array}{l}\text { Medidas de saúde devem ser aplicadas a veículos, } \\
\text { cargas e pessoas em trânsito internacional para } \\
\text { conter riscos. }\end{array}$ & $\begin{array}{l}\text { Medidas de saúde devem ser aplicadas a veículos, } \\
\text { cargas e pessoas em trânsito internacional para } \\
\text { conter riscos. }\end{array}$ \\
\hline & $\begin{array}{l}\text { Estados devem implentar e manter capacidades para } \\
\text { detectar, inspecionar e responder às doençãso } \\
\text { infecciosas objeto do tratado nos pontos de } \\
\text { fronteira. }\end{array}$ & $\begin{array}{l}\text { Estados devem implantar e manter capacidades de } \\
\text { saúde pra detectar, avaliar, relatar e responder às } \\
\text { ameaças à saúde pública nos níveis nacional, } \\
\text { intermediário e local. }\end{array}$ \\
\hline & Não faz refererência aos direitos humanos. & $\begin{array}{l}\text { Considera direitos humanos no tratamento dos } \\
\text { indivíduos no contexto de uma ESPII. }\end{array}$ \\
\hline \multirow{3}{*}{$\begin{array}{l}\text { COMPONETES } \\
\text { PROCESSUAIS }\end{array}$} & \multirow{3}{*}{ Não há. } & $\begin{array}{l}\text { Dispõe de protocolo decisório (anexo II) que } \\
\text { padroniza a ação das autoridades nacionais na } \\
\text { identificação de uma possível ESPII. }\end{array}$ \\
\hline & & $\begin{array}{l}\text { Recomendações temporárias emitidas pelo Diretor- } \\
\text { geral e Comitê de Emergência para inferir nas nas } \\
\text { respostas dos países a uma determinada ESPII. }\end{array}$ \\
\hline & & $\begin{array}{l}\text { Recomendações permanentes emitidas pelo Diretor- } \\
\text { geral e Comitê de Revisão para auxiliar países na } \\
\text { implementação das capacidades básicas de saúde } \\
\text { pública. }\end{array}$ \\
\hline
\end{tabular}

Agrega diversos tipos de riscos, inclusive as DIEs, na concepção de "emergências de saúde pública de importância internacional" (ESPII).

Estados são obrigados a informar a OMS sobre

oficiais como, po exemplo, mídia, redes de monitoramento e organismos não-governamentais.
Estipula "medidas máximas" aplicáveis para evita interferências desnecessárias com o comércio e os riscos à saúde humana evitando interferêncin desnecessária no comércio e tráfego internacionais.

Medidas e capacidades de saúde estipuladas são

Medidas e capacidades de saúde estipuladas dizem cha a orgizaco nacional para conter iscos.

Medidas de saúde devem ser aplicadas a veículo cargas e pessoas em trânsito internacional para conter riscos.
Estados devem implentar e manter capacidades para Estados devem implantar e manter capacidades d detectar, inspecionar e responder às doençãso saúde pra detectar, avaliar, relatar e responder à infecciosas objeto do tratado nos pontos de ameaças à saúde pública nos níveis nacional, rmediário e local.

Considera direitos humanos no tratamento do indivíduos no contexto de uma ESPII

Déco de protocolório (anexo II) que padroniza a ação das autoridades nacionais $n$ dentificação de uma possível ESPII.

Recomendações temporárias emitidas pelo Diretorgeral e Comitê de Emergência para inferir nas nas

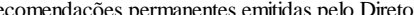
pública. com as ESPII nos níveis nacional, intermediário e local. 
A governança internacional das DIEs se desenvolveu com o surgimento de um regime especificamente voltado para essa matéria. Esse regime nasceu da revisão de um componente substantivo do RSI 1969: a ampliação do seu escopo. Nesse sentido, a adoção do conceito de "emergências de saúde pública de importância internacional” para resolver a limitação às doenças específicas foi a mudança fundamental nesse regime, pois ampliou a diversidade de riscos à saúde pública aos quais o tratado se refere. Dessa forma, o regime de alerta, controle e resposta às DIEs surge da transformação de um regime anterior sobre um número reduzido de doenças infecciosas (cólera, peste e febre amarela) em um regime abrangente sobre ESPII - conceito que incorpora as DIEs.

A versão mais recente desse tratado denota, então, uma mudança da percepção da comunidade internacional acerca dos riscos que as doenças infecciosas representam (YOUDE, 2011). Essa evolução está alinhada com a ideia da terceira transição epidemiológica (BARRETT et al., 1998), tendência evidenciada pelo reaparecimento de doenças infecciosas anteriormente controladas, a resistência microbiana aos antibióticos e o surgimento de novas doenças. Esses fatores apontam para a gravidade dos riscos associados às DIs, e, em especial às DIEs. Na análise realizada, observou-se que o RSI 2005 procura contemplar esses riscos, estruturando um regime que abarca as DIEs.

Ademais, o RSI 2005 atualiza e aprimora diversas normas de sua versão anterior. Observou-se o aprofundamento nos três componentes investigados. Em relação ao componente substantivo, os principais avanços referem-se à definição de medidas mínimas de saúde pública necessárias para lidar com os riscos; o reconhecimento da importância de outros atores no sistema de vigilância epidemiológica; a sistematização dos protocolos de comunicação entre a OMS e os Estados-parte com a figura do Ponto Focal Nacional; e, a determinação de como os Estados devem se organizar domesticamente para combater as ESPII na sua origem, com foco especial para a implantação de capacidades básicas nacionais.

O novo regulamento inova ao estabelecer componentes processuais para o funcionamento do regime com a adoção de regras sobre o trabalho do Diretor-geral com os comitês de emergência e de revisão e com a adoção do instrumento de decisão para avaliação e notificação dos eventos que possam constituir ESPII. Essas mudanças identificadas na comparação dos componentes das duas edições do tratado apontam para o aprofundamento da governança não só das DIEs, mas também dos riscos à saúde pública de outras naturezas.

Em suma, os avanços identificados no RSI 2005 apontam para o aprimoramento e qualificação do regime internacional das DIE. A partir do modelo analítico de Young (1999), 
o fortalecimento desse regime, por sua vez, explica o desenvolvimento da governança para essa mesma matéria.

Por fim, é importante esclarecer que a pesquisa apresentada nesse capítulo não tem intuito de ser uma análise exaustiva sobre a governança das DIEs. Uma possibilidade de desenvolvimento futuro dessa agenda de pesquisa poderia se dar abordando iniciativas recentes como, por exemplo, o "Pandemic Influenza Preparedness" - que estabelece um protocolo para a resposta internacional à gripe pandêmica, firmando normas para o compartilhamento de cepas de vírus e distribuição de vacinas (WORLD HEALTH ORGANIZATION, 2011) - e o "Emergency Response Framework" - que organiza o envolvimento da OMS e dos Estados-parte em emergências internacionais de natureza diversa, como, catástrofes naturais, acidentes em larga escala, conflitos e epidemias (WORLD HEALTH ORGANIZATION, 2013c).

Além disso, acredita-se que a investigação acerca do papel dos atores e dispositivos mediatos na governança das DIEs, conforme discutido na introdução, possa ajudar a caracterizar melhor de que forma a comunidade internacional se organiza para lidar com a ameaça que o surgimento de novas doenças representa. 


\section{CONCLUSÃO}

Essa dissertação procurou compreender de que maneira se estrutura a governança de uma nova dimensão de segurança internacional: as doenças infecciosas emergentes.

O primeiro capítulo ocupou-se em discutir de que forma o tema das doenças infecciosas é interpretado como uma das novas dimensões de segurança internacional. Foi ressaltado que essa compreensão do fenômeno não quer dizer que as DIs sejam um desafio moderno para a comunidade internacional. Ao contrário, caracterizar as doenças infecciosas como novas dimensões de segurança serve para ressaltar que só recentemente esse tema tem sido analisado sob esse prisma - especialmente no campo acadêmico das Relações Internacionais. Com isso, essa dissertação propôs cinco abordagens, encontradas na literatura especializada, para essa relação. Cada uma dessas abordagens caracteriza um entendimento particular de como as DIs representam riscos aos Estados, sociedades, grupos e indivíduos na atualidade. Essas vertentes explicativas variam quanto à ontologia e aos níveis de análise adotados. A abordagem que enfatiza o impacto direto das DIs sobre a segurança nacional e defesa dos Estados - seja afetando continentes militares ou por meio do uso de armas biológicas, por exemplo - é a que mais se aproxima dos entendimentos neorrealistas na teoria das relações internacionais. A identificação de outras quatro abordagens aponta para a incapacidade da abordagem tradicional de abarcar o problema das DIs em sua completude. A diversidade dessas cinco abordagens tomadas em conjunto permite supor que as doenças infecciosas são uma dimensão de segurança internacional.

A partir dessas considerações, foi necessário investigar qual a forma adequada de compreender a governança das doenças infecciosas emergentes. O objetivo específico nessa parte do estudo foi definir se as DIEs eram objeto de governança internacional ou global, segundo nomenclatura adotada por Fidler (2002). Para tanto, num primeiro momento, procurou-se apresentar os desenvolvimentos teóricos sobre governança provenientes tanto do campo das Relações Internacionais quando dos estudos da saúde global. Notou-se a proximidade dessa discussão em ambos os campos, especialmente acerca da inclusão de novos atores (além de Estados e organizações internacionais) como participantes da governança, traduzida na diferenciação entre governança global e internacional.

Foi necessário caracterizar a agenda da saúde global como uma coleção de diferentes temas que, quando agrupados sob esse conceito, dão forma a um emaranhado complexo de áreas de trabalho que compartilham entre si o fato de estarem diretamente relacionados com a 
saúde das populações a nível internacional. A partir dessa definição, e após descrever os atores, programas políticos e principais normas internacionais relacionadas ao controle e resposta às doenças infecciosas, defende que essa "sub-agenda" da saúde global é objeto de governança global - pois envolve uma pluralidade de atores, para além do Estado e OIs. Percebeu-se, contudo, que a agenda das DIEs, se tomada à parte, é mais bem caracterizada como sujeita à governança internacional. Três são as razoes encontradas para essa definição: (1) a dimensão de emergência que o surgimento de novas doenças envolve; (2) a ausência de atores não-estatais engajados no seu tratamento; e, (3) o fato de as normas internacionais que constituem o regime de controle das DIEs são consistentemente resultado da atuação dos Estados e dos OIs.

Com isso, o último capítulo foi dedicado à análise da governança internacional das DIEs. Isso foi realizado abordando um regime internacional específico materializado no Regulamento Sanitário Internacional - o principal dispositivo normativo imediato sobre essa matéria. Foi discutida a forma com que, apesar da sua inaplicabilidade às DIEs, a ineficácia e limitação do RSI 1969 abriram margem para a ascensão da estratégia de "global health security" na década de 1990. Essa estratégia, por sua vez, lançou as bases e serviu de fundamento para a reestruturação do regime com a aprovação do RSI 2005. Com isso, o RSI 2005 consolida uma série de novas estratégias que vinham sendo discutidas e desenvolvidas no bojo da OMS desde a década de 1990 e que compõem o paradigma de global health security. Dentre essas estratégias, destaca-se a relevância de reestruturação das atividades de alerta, controle, prevenção e resposta às DIEs - o que aponta para uma ressignificação de como a comunidade internacional percebe os riscos colocados por esse fenômeno.

Isso aponta que a ressignificação do risco que as DIEs representam à comunidade internacional é uma força motriz que levou à revisão do RSI (YOUDE, 2011). O processo de revisão desse tratado, por sua vez, denota a transformação do regime. Segundo tipologia proposta por Young $(1989$, p.352) acerca da dinâmica dos regimes internacionais, essa é uma transformação do terceiro tipo, que se dá com o intuito de "simplificar ou tornar racional um regime que tenha se tornado ambíguo ou contraditório no curso de sua evolução".

A partir dos resultados apresentados ao longo dos três capítulos dessa dissertação, é possível identificar diversas possibilidades do aprofundamento dessa agenda de pesquisa. Em primeiro lugar, seria interessante compreender de que forma as cinco abordagens da relação entre doenças infecciosas e segurança internacional subsidiam políticas internacionais. Para tanto, caberia uma análise sistemática da apropriação dessas diferentes abordagens pelas organizações internacionais na elaboração em programas e projetos de cooperação, nas 
doutrinas de atuação de atores não-estatais, e também como elementos na condução da política externa de determinados países.

Ressalta-se também a importância de compreender melhor o papel e o impacto das redes de vigilância epidemiológica nessa agenda. Como é demonstrado ao longo dessa pesquisa, a partir dos anos 1990 uma miríade de novos atores tem se organizado - algumas vezes até mesmo paralelamente às políticas públicas internacionais - para monitorar casos de doenças infecciosas pelo mundo. Sobre esse fenômeno, é importante compreender melhor qual o real impacto dessas redes na governança política dos riscos colocados pelas doenças infecciosas, especialmente daquelas com potencial epidêmico e pandêmico. Caberia analisar, por exemplo, a atuação das redes de vigilância epidemiológica a partir do modelo analítico da teoria de redes, buscando caracterizar esses atores como frutos da "information revolution" (ARQUILLA; RONFELDT, 2001).

Com base na análise do RSI oferecida nessa dissertação, seria importante procurar compreender a fundo a atuação de determinados Estados na implementação de tais normas. Nesse sentido, caberia investigar o estado atual da adequação nacional aos requisitos estipulado pela norma e a observância dos países a determinadas regras do Regulamento. Também seria interessante procurar entender a participação desses Estados no processo de elaboração das referidas normas componentes do RSI 2005 - investigação essa que poderia facilitar um mapeamento mais geral sobre a política externa dos países na área da saúde.

Ademais, valeria a pena realizar uma análise abrangente e sistemática sobre os diversos programas e iniciativas da OMS que contribuem para a governança das DIEs - para além do RSI. Para expandir essa linha de investigação, caberia ainda abordar a atuação dos vários organismos internacionais que, direta ou indiretamente, influenciam para a governança dessa agenda.

Essa pesquisa corrobora a importância da aproximação dos campos de Relações Internacionais, especialmente da área de estudo de segurança internacional, e da saúde pública. Tradicionalmente tratados à parte pelas suas comunidades científicas e profissionais, ambos os campos poderiam se beneficiar de uma aproximação que propiciasse o intercâmbio de experiências, o compartilhamento de informações e auxiliasse na elaboração conjunta de políticas e programas. Acredita-se que isso possa ser extremamente valioso especialmente para os temas interdisciplinares e suas agendas sobrepostas - como é o caso do impacto internacional das doenças infecciosas, por exemplo. É nesse âmbito que essa pesquisa procurou contribuir avaliando como desafios consolidados e persistentes da saúde pública são, 
hoje, entendidos como problemas de segurança internacional quando tratados no campo das Relações Internacionais.

Em suma, fica claro que a atual versão do Regulamento Sanitário Internacional é um produto da governança internacional das doenças infecciosas emergentes. Essa peça é um bom exemplo dos resultados da dinâmica da governança conforme caracterizada por Fidler (2002). A ocorrência de um "problema global" (no caso, o risco colocado pelas DIEs) força os Estados a internacionalizarem suas políticas - em outras palavras, os Estados buscam uma solução comum e coordenada para o problema. Essa internacionalização foi atentamente observada nesta pesquisa quando analisada a atuação da OMS nessa agenda, organização que detém a prerrogativa internacional para orquestrar a cooperação internacional no tocante aos temas da saúde pública. O tratamento desse problema no bojo da OMS se intensificou especialmente a partir dos anos 1990, com o início do processo de revisão do Regulamento e com o surgimento da estratégia global health security. A disseminação dessa estratégia no âmbito da OMS pode ser vista como um exemplo de processo de securitização das doenças infecciosas, referido pela abordagem securitizadora. Dessa forma, o produto dos esforços de securitização e internacionalização desse problema comum colocado pelas DIEs é o próprio RSI, norma internacional que, ao demandar incorporação jurídica doméstica, culmina na alteração do comportamento dos Estados frente à ameaça das DIEs.

Conclui-se, então, que, nas últimas décadas, ocorreu o desenvolvimento da governança internacional das DIEs com o surgimento de um regime especificamente voltado para essa matéria. Esse regime nasceu a partir da transformação um regime anterior de controle da propagação internacional de uma limitada lista de doenças (peste, cólera e febre amarela), em um regime abrangente sobre "emergências de saúde pública de importância internacional”. 


\section{REFERENCIAS}

ANVISA. Regulamento Sanitário Internacional. Brasília: Anvisa, 2007.

ARQUILLA, J.; RONFELDT, D. The Advent of Netwar. In: Networks and Netwars: the future of terror, crime and militancy. Santa Monica: RAND, 2001.

BIRMINGHAM MAIL. Birmingham Mail feature: When Birmingham was gripped by deadly smallpox virus. 2011. Disponível em: <http://www.birminghammail.co.uk/news/local-news/birmingham-mail-feature-whenbirmingham-was-gripped-155391>. Acesso em: 24 out. 2014.

BUNCOMBE, Andrew. Pakistan: Bombs kill 12 in attacks on police officers guarding polio vaccination teams. 2014. Disponível em: <http://www.independent.co.uk/news/world/asia/bombs-kill-12-in-atta...ani-police-officersguarding-polio-vaccination-teams-9162268.html>. Acesso em: 23 out. 2014.

ABC. Egypt starts pig slaughter to ward off flu. 2009. Disponível em: <http://www.ph.ucla.edu/epi/faculty/detels/ph150/chap9-17_otph5.pdf >. Acesso em: 30 out. 2014.

ACKERMAN, Gary; MORAN, Kevin. Bioterrorism and Threat Assessment. Stockholm: Weapons of Mass Destruction Commission, n.22, 2006.

AGINAM, O. Between isolationism and mutual vulnerability a south-north perspective on global governance of epidemics in an age of globalization. Temple Law Review, v.77, 2004.

AGINAM, O. Globalization of Health Insecurity: The World Health Organization and the New International Health Regulations. Medicine and Law, v.25, 2006.

AGINAM, O. International law and communicable diseases. Bulletin of the World Health Organization, v.80, n.12, 2002.

AKEN, Jan; HAMMOND, Edward. Genetic engineering and biological weapons. EMBO reports, v.4, 2003.

ALLIN, Nancy. The AIDS Pandemic: International Travel and Immigration Restrictions and the World Health Organization's Response. Va J. Int'I Law, v.28, 1988.

ANDRUS, J. K. et al. Global health security and the International Health Regulations. BMC Public Health, v.10, 2010.

ANEMA, Aranka et al. Descriptive review and evaluation of the functioning of the International Health Regulations (IHR) Annex 2. Globalization and Health, v.8, n.1, 2012.

ANVISA. Regulamento sanitário internacional. Brasília: Anvisa, 2007. 
ASSOCIATED PRESS. Polio's return due to vaccine fears in Nigeria. 2006. Disponível em: <http://www.nbcnews.com/id/15005238/ns/health-infectious_diseases/t/rumors-causeresistance-vaccines-nigeria/\#.UyRLy9xI1w0>. Acesso em: 23 out. 2014.

ATLAS, Ronald M. The threat of bioterrorism returns the fear of smallpox. Current Opinion in Microbiology, v.1, 1998.

BAKER, Michael G.; FIDLER, David P. Global public health surveillance under new international health regulations. Emerging Infectious Diseases, v.12, n.7, 2006.

BAKHSHI, Surinder. 1978 Accidental Birmingham laboratory Release of smallpox virus Are lessons learnt relevant today? BMJ, v.325, 2003.

BALDWIN, David A. The concept of security. Review of International Studies, v.23, 1997.

BAN, Jonathan. Health as a Global Security Challenge. Seton Hall Journal of Diplomacy and International Relations, v.4, 2003.

BARNETT, Michael; FINNEMORE, Martha. Rules for the World: International Organizations in Global Politics. Ithaca: Cornwell University Press, 2004.

BARRETT, R. et al. Emerging and re-emerging infectious diseases: the third epidemiologic transition. Annu. Ver. Anthropol., v.27, 1998.

BERCHE, Patrick. The threat of smallpox and bioterrorism. Trends in microbiology, v.9, n.1, 2001.

BOCCACCIO, Giovanni. The Decameron or ten days entertainement of Boccaccio. Londres: Chatto \& Windus, 1872.

BREULH, J. Epidemiología crítica: ciencia emancipadora e interculturalida. Buenos Aires: Lugar Editorial, 2003.

BROWN, C. M.; CETRON, M. S. Crossing Borders: One World, Global Health. Clinical Infectious Diseases, v.54, n.11, 2012.

BROWN, G.W. Distributing who gets what and Why: four normative approaches to global health. Global Policy, v.3, 2012.

BRUNDTLAND, Gro Harlem. Global Health and International Security. Global Governance, v.9, n.4, out/dez, 2003.

BUZAN, Barry, et al. Security: a new framework for analysis. London: Lynne Rienner Publishers, 1998.

BUZAN, Barry. Rethinking Security after the Cold War. Cooperation and Conflict, v.32, n.1, p.5-28, 1997.

BUZAN, Barry. Rethinking Security after the Cold War. Cooperation and Conflict, v.32, n.1, p.5-28, 1997. 
BUZAN, Barry; WAEVER, Ole. Regions and Powers: The Structure of International Security. Cambridge: Cambridge University Press, 2003.

CAINES, Karen. Assessing the impact of global health partnerships. 2004. Disponível em: <http://www2.ohchr.org/english/issues/development/docs/WHO_synthesis.pdf >. Acesso em: 30 out. 2014.

CALAIN, Philippe. Exploring the international arena of global public health surveillance. Health Policy and Planning, v.22, 2007.

CAMUS, Albert. The Plague. Vintage International, Nova Iorque, 1991.

CASH, Richard; NARASIMHAN, Vasant. Impediments to global surveillance of infectious diseases: consequences of open reporting in a global economy. Bulletin of the World Health Organization, v.78, n.11, 2000.

CASTILlO-SAlGADO, Carlos. Trends and Directions of Global Public Health Surveillance. Epidemiol Ver, v.32, n.1, 2010.

CENTERS FOR DISEASE CONTROL AND PREVENTION. Preventing Emerging Infectious Diseases: A Strategy for the 21st Century: Overview of the Updated CDC Plan. $1998 . \quad$ Disponível em: <http://www.cdc.gov/mmwr/preview/mmwrhtml/00054779.htm>. Acesso em: 30 out. 2014.

CHECK, E. Global health agency split over potential anti-terrorist duties. Nature, v.434, 2005.

CHOW, J.C. Health and International Security: U.S. Policy on World Health. The Washington Quarterly, v.19, n.2, 1996.

CHRETIEN, J.P. US Military Global Health Engagement since 9/11: Seeking Stability through Health. Global Health Governance, v.4, n.2, 2011.

CNN. China hid SARS patients - report. 2003. Disponível em: <http://edition.cnn.com/2003/WORLD/asiapcf/east/04/18/sars.china/>. Acesso em: 31 out. 2014.

COMMISSION ON GLOBAL GOVERNANCE. Our Global Neighbourhood. The Report of the Commission on Global Governance. Oxford: Oxford University Press, 1995.

DASILVA, E.; IACCARINO, M. Emerging diseases: a global threat. Biotechnology Advances, v.19, 1999.

DAVIES, S. E. Secutirizing infectious diseases. International Security, v.84, n.2, 2008.

DAVIES, S. What contribution can International Relations make to the evolving global health agenda?. International Affairs, v.86, n.5, 2010. 
DAWOOD et al. Estimated global mortality associated with the first 12 months of 2009 influenza A H1N1 pandemic: virus circulation: a modeling study. The Lancet, v.12, set.2012.

DIAMOND, Jared M. Guns, Germs, and Steel: The Fates of Human Societies. New York: Norton, 1999.

DICKERSON, C.; GRILLS, N. The world health organization engaging with civil society networks to promote primary health care. Global Health Governance, v.6, n.1, 2012.

DODGSON et al. Global Health Governance: A Conceptual Review. Discussion paper n.1. Genebra: World Health Organization, 2002. Disponível em: $<$ http://www.bvsde.paho.org/texcom/cd050853/dodgson.pdf > Acesso em: 15 de novembro de 2013.

DOYLE, Cathal; PATEL, Preeti. Civil society organisations and global health initiatives: Problems of legitimacy. Social Science \& Medicine, v.66, 2008.

ELBE, Stefan. Should HIV/AIDS Be Securitized? The Ethical Dilemmas of Linking HIV/AIDS and Security. International Studies Quarterly, v.50, n.1, 2006.

ENEMARK, Christian. Health Security Challenges Biological Weapons and Pandemic Influenza. Security Challenges, v.3, n.3, 2007.

ENEMARK, Christian. The role of the Biological Weapons Convention in disease surveillance and response. Health Policy and Planning, v.25, 2010.

FAMRER, Paul. Social Inequalities and Emerging Infectious Diseases. Emerging Infectious Diseases, v.2, n.4, 1996.

FAUCI, A. MORENS, D. M. The Perpetual Challenge of Infectious Diseases. The New England journal of medicine, v.366, n.5, 2012.

FIDLER, David. Emerging trends in international law concerning global infectious disease control. Emerging Infectious Diseases, v.9, n.3, 2003a.

FIDLER, David. Germs, governance, and global public health in the wake of SARS. Journal of Clinical Investigation, v.113, n.6, 2004.

FIDLER, David. Globalization, international law, and emerging infectious diseases. Emerging Infectious Diseases, v.2, n.2, 1996.

FIDLER, David. Microbialpolitik: Infectious Diseases and International Relations. American University International Law Review, v.14, n.1, 1998.

FIDLER, David. SARS: political pathology of the first post-Westphalian pathogen. Journal of Law, Medicine and Ethics, v.31, n.4, 2003b.

FIDLER, David. The Challenges of Global Health Governance. In: COUNCIL ON FOREIGN RELATIONS. Working Paper. Maio, 2010. Disponível em: 
<http://www.cfr.org/global-governance/challenges-global-health-governance/p22202>.

Acesso em: 31 out. 2014.

FIDLER, David. The Globalization of public health: emerging infectious diseases and international relations. Indiana Journal of Global Legal Studies, v.5, n.1, 1997a.

FIDLER, David. The role of international law in the control of emerging infectious diseases. Bull. Inst. Pasteur, v.95, 1997 b.

FIDLER, David. From International Sanitary Conventions to Global Health Security: The New International Health Regulations. Chinese Journal of International Law, v.4, n.2, 2005 .

FIDLER, David. Global health governance: overview of the role of international law in protecting and promoting global public health. 2002. Disponível em: <http://apps.who.int/iris/handle/10665/68936>. Acesso em: 31 out. 2014.

FIDLER, David. Return of the Fourth Horseman: Emerging Infectious Diseases and International Law. 1997c. Disponível em: <http://www.repository.law.indiana.edu/facpub/746>. Acesso em: 31 out. 2014.

FIDLER, D.; GOSTIN, L. The New International Health Regulations: An Historic Development for International Law and Public Health. Journal of Law Medicine and Ethics, v.34, n.1, 2006.

FINKELSTEIN, Lawrence. What Is Global Governance? Global Governance, v.1, n. 3, 1995.

FOOD AND AGRICULTURE ORGANIZATION. FAO Regional Strategy for highly pathogenic avian influenza and other emerging infectious diseases of animals in Asia and the Pacific. Bangkok: Food and Agriculture Organization, 2010.

FOOD AND AGRICULTURE ORGANIZATION. The Global Satrategy for prevention and control of H5N1 highly pathogenic avian influenza. Roma: FAO, 2008.

FRANZEN, Carl. Killer cure: why is the US creating new viruses and stockpiling the vaccines? 2013a. Disponível em: <http://www.theverge.com/2013/4/17/4227570/projectbioshield-vaccine-stockpiling-bird-flu-avian-influenza>. Acesso em: 24 out. 2014.

FRANZEN, Carl. Scientists to begin making super strains of H7N9 bird flu, funded in part by US government. 2013b. Disponível em: <http://www.theverge.com/2013/8/7/4598298/super-strains-of-h7n9-bird-flu-experimentscoming >. Acesso em: 24 out. 2014.

FRASER, Claire; DANDO, Malcolm. Genomics and future biological weapons: the need for preventive action by the biomedical community. Nature genetics, v.29, 2001.

GABLE, L. The proliferation of human rights in global health governance. J Law Med Ethics, v.35, n.4, 2007. 
GAVI ALLIANCE. GAVI Alliance Progress Report 2010. 2010. Disponível em: <http://www.gavi.org/Library/Publications/GAVI-Progress-reports/GAVI-Alliance-ProgressReport-2010/>. Acesso em: 30 out. 2014.

GIORGETTI, Chiara. International health emergencies in failed and failing states. Georgetown Journal of International Law, v.44, 2013.

GOFFMAN, Erving. Frame Analysis: An Essay on the Organization of Experience. Harvard University Press, 1974.

GOSTIN, Lawrence O. International Infectious Disease Law Revision of the World Health Organization's International Health Regulations. Health Law and Ethics, v.291, n.21, 2004.

GOTTRON, Frank. Project BioShield: Purposes and Authorities. Washington: Congressional Research Service, 2009.

GUBLER, Duane; CLARK, Gary. Dengue/Dengue Hemorrhagic Fever: The Emergence of a Global Health Problem. Emerging Infectious Diseases, v.1, n.2, 1995.

GUERNIER, V. et al. Ecology drives the worldwide fistribution of human diseases. Plos Biology, v.2, n.6, 2004.

HAAS, Peter. Introduction: epistemic communities and international policy coordination. International organization, v.46, n.1, 1992.

HANSEN, Lene. A Case for Seduction? Evaluating the Poststructuralist Conceptualization of Security. Cooperation and Conflict, v.32, n.4, p.369-397, 1997.

HARDIMAN, M. The revised International Health Regulations: a framework for global health security. International Journal of Antimicrobial Agents, v.21, 2003.

HARDIMAN, M. World Health Organization perspective on implementation of International Health Organization. Emerging Infectious Diseases, v.18, n.7, 2012.

HARMAN, S. Global Health Governance. London: Routledge; 2012.

HENDERSON, D.A. Bioterrorism as a Public Health Threat. Emerging Infectious Diseases, v. 4, n. 3, 1998.

HENDERSON, D.A. Smallpox Virus Destruction and the Implications of a New Vaccine. Biosecurity and Bioterrorism, v.9, n.2, 2011.

HEWLETT, B.; HEWLETT, B. Ebola, culture and politics: the anthropology of an emerging disease. Wadsworth Books, 2008.

HEYMANN, David L. Emerging and re-emerging infections. In: DETELS, R.; BEAGLEHOLE, R. Oxford Textbook of Public Health. Oxford: Oxford Univesity Press, 2009. 
HEYMANN, David L. SARS and Emerging Infectious Diseases: A Challenge to Place Global Solidarity above National Sovereignty. Ann Acad Med Singapore, v.35, 2006.

HOTEZ, Peter J. Vaccine diplomacy. Foreign Policy. 2001. Disponível em: http://www.foreignpolicy.com/articles/2001/05/01/vaccine_diplomacy. Acessado em: 23 out. 2014.

HOTEZ, Peter J. Combating diseases of poverty requires joint US-Middle East effort. 2012. Disponível em: <http://www.globalpost.com/dispatches/globalpostblogs/commentary/joint-poverty-combat-mid-east>. Acesso em: 23 out. 2014.

HOTEZ, Peter J. Peace Through Vaccine Diplomacy. 2010. Disponível em: $<$ http://www.sciencemag.org/content/327/5971/1301.full?ijkey=2u50HpUDPEZZU\&keytype $=$ ref\&siteid=sci $>$. Acesso em: 23 out. 2014.

HOTEZ, Peter J. Polio and vaccine diplomacy in Pakistan. 2012. Disponível em: <http://blog.chron.com/bakerblog/2012/12/polio-and-vaccine-diplomacy-in-pakistan-2/>. Acesso em: 23 out. 2014.

HOYT, Kendall; BROOKS, Stephen G. A Double-Edged Sword: Globalization and Biosecurity. International Security, v.28, n.3, 2003.

IGNATIUS, David. The threat to global health from the hunt for bin Laden. 2012. Disponível em: <http://www.washingtonpost.com/opinions/a-cia-gambit-in-pakistan...s-aglobal-vaccination-program/2012/05/29/gJQAW6W1zU_story.html>. Acesso em: 23 out. 2014.

JEZEK, Z. Tasks in the wake of smallpox erradication. World Health Forum, v.8, 1987.

JYIN, Jiyong; KARACKATTU, Joe Thomas. Infectious diseases and securitization: WHO's dilemma. Biosecurity and Bioterrorism: Biodefense Strategy, Practice and Science, v.9, n.2, 2011.

KADLEC, Robert. Renewing the Project BioShield Act. Washington: Center for a New American Security, 2013.

KASPERSON, Roger E. et al. The Social Amplification of Risk: a conceptual framework. Worcester, Clark University, 1989.

KATZ, R. Use of Revised International Health Regulations during Influenza A (H1N1) Epidemic, 2009. Emerging Infectious Diseases, v.15, n.8, 2009.

KATZ, R.; FISCHER, J. The Revised International Health Regulations: A Framework for Global Pandemic Response. Global Health Governance, v.3, n.2, 2010.

KELLE, Alexander. Securitization of International Public Health: Implications for Global Health Governance and the Biological Weapons Prohibition Regime. Global Governance, v.13, 2007. 
KELLEY, Patrick. Global health governance and policy development. Infect Dis Clin N Am, n. 25, 2011.

KEOHANE, Robert O. After Hegemony: Cooperation and Discord in the World Political Economy. Princeton: Princeton University Press, 1984.

KEOHANE, Robert; NYE, Joseph. Power and Interdependence: world politics in transition. Boston: Brown, 1977.

KICKBUSCH, Ilona. The need for a European strategy on global health. Scandinavian Journal of Public Health, v.34, n.6, 2006.

KING, Gary; MURRAY, Christopher. Rethinking Human Security. Political Science Quarterly, v. 116, n.4, p.585-611, 2001.

KNOBLER, Stacey et al. Learning from SARS: Preparing for the Next Disease Outbreak -- Workshop Summary. 2004. Disponível em: <http://www.nap.edu/catalog/10915.html>. Acesso em: 30 out. 2014.

KOPLAN, J.P. et al. Towards a common definition of global health. Lancet, v.373, n. 9679, 2009.

KRASNER, S.D. Structural causes and regime consequences: regimes as intervening variables. In: International Regimes. Cornwell University Press, 1983.

KRAUSE, Keith. The Research Program of "Critical Security Studies". Cooperation and Conflict, v.33, n.3, p.-298-333, 1998.

KRAUSE, Keith; WILLIAMS, Michael C. Broadening the Agenda of Security Studies: Politics and Methods. Mershon International Studies Review, v. 40, n. 2, 1996.

LABONTE, R.; SCHRECKER, T. Globalization and social determinants of health: Promoting health equity in global governance (part 3 of 3). Global Health, v.3, n.7, 2007.

LAXMINARAYAN, R. et al. Incentives for Reporting Disease Outbreaks. PLOS One, v.9, n.3, 2014.

LEACH, Melissa et al. Governing epidemics in na age of complexity: narratives, politics and pathways to sustainability. Global Environmental Change, v.20, 2010.

LEE, K.; DODGSON, R. Globalisation and cholera: Implications for global governance. Global Governance, v.6, n.2, 2000.

LEE, K.; KAMRADT-SCOTT, A. The multiple meanings of global health governance: a call for conceptual clarity. Globalization and Health, v.10, n.28, 2014.

LEVINE, Orin; GARRETT, Laurie. The fallout from the CIA's vaccination ploy in Pakistan. 2011. Disponível em: <http://www.washingtonpost.com/opinions/the-fallout-fromthe-cias-vaccination-ploy-in-pakistan/2011/07/15/gIQASu12GI_story.html>. Acesso em: 23 out. 2014. 
LIGON, L. Smallpox: its history and reemergence as a weapon of biological warfare. Journal of Pediatric Infectious Diseases, v.12, n.1, 2001.

LOB-LEVYT, Julian. Contribution of the GAVI Alliance to improving health and reducing poverty. Phil. Trans. R. Soc. B, v.366, 2011.

LOPPACHER, Laura; KERR, William. The Efficacy of World Trade Organization Rules on Sanitary Barriers: Bovine Spongiform Encephalopathy in North America. Journal of World Trade, v.39, 2005.

LOUGHLIN, Kelly; BERRIDGE, Virginia. Global Health Governance - historical dimensions of global governance. In: WORLD HEALTH GORGANIZATION, Discussion paper n.2, março, 2002.

LYNN, Jonathan. Swine flu alert prompts pork import bans. 2009. Disponível em: < http://www.reuters.com/article/2009/04/27/idUSN27533817>. Acesso em: 30 out. 2014.

MACFARLANE, S.B. et al. In the name of global health: trends in academic institutions. Public Health Policy, v.29, n.4, 2008.

MACKENZIE, John S. et al. Emerging flaviruses the spread and resurgence of japanese ancephalitis west nile and dengue viruses. Nature Medicine, v.10, n.12, 2004.

MACLEAN, George. The Changing Perception of Human Security: Coordinating National and Multilateral Responses, The United Nations and the New Security Agenda. 1998. Disponível em: <www.unac.org/canada/securitv/maclean.html>. Acesso em: 29 de out. de 2014.

MACLEAN, Sandra. Microbes, Mad Cows and Militaries: Exploring the Links Between Health and Security. Security Dialogue, v.39, n.5, 2008.

MATHEWS, Jessica Tuchman. Redefining Security. Foreign Affairs, v.68, n. 2, p.162-177, Spring 1989.

MCDOUGALL, Christopher et al. Protecting global health security through the International Health Regulations: requirements and challenges. Canadian Medical Association Journal, v.179, n.1, 2008.

MCINNES, C.; LEE, K. Health and Security. Politik, v.8, n.1, 2005.

MCINNES, Colin; LEE, Kelley. Health, security and foreign policy. Review of International Studies, v.32, n.1, 2006.

MCNEIL, Donald. C.I.A. Pakistan Battles Polio, and Its People's Mistrust. 2013b. Disponível em: <http://www.nytimes.com/2013/07/22/health/pakistan-fights-for-ground-inwar-on-polio.html?pagewanted=all\&_r=0>. Acesso em: 23 out. 2014. 
MCNEIL, Donald. C.I.A. Vaccine Ruse May Have Harmed the War on Polio. 2012. Disponível em: <http://www.nytimes.com/2012/07/10/health/cia-vaccine-ruse-in-pakistanmay-have-harmed-polio-fight.html?pagewanted=all\&_r=4\&>. Acesso em: 23 out. 2014.

MCNEIL, Donald. Gunmen Kill Nigerian Polio Vaccine Workers in Echo of Pakistan Attacks. 2013a. Disponível em: <http://www.nytimes.com/2013/02/09/world/africa/innigeria-polio-vaccine-workers-are-killed-by-gunmen.html>. Acesso em: 23 out. 2014.

MCNEIL, William. Plagues and Peoples. Garden City: Anchor Press, 1976.

MEIER, B.M.; ONZIVU, W. The evolution of human rights in WHO policy and the future of human rights through global health governance. Public Health, v.128, n.2, 2014.

MORAN, Michael. Philanthropic foundations and the governance of global health: The Rockefeller Foundation and Product Development Partnerships. 2007. Disponível em: $<$ http://www.eisa-net.org/be-bruga/eisa/files/events/turin/Moran-

TheRockefellerFoundationandPDPs.pdf>. Acesso em: 29 out. 2014.

MORSE, Stephen. Factors in the Emergence of Infectious Diseases. Emerging Infectious Diseases, v.1, n.1, 1995.

MURRAY, C. Social, economic and operational research on tuberculosis: recent studies and some priority questions. Bull International Union Tuberc Lung Dis, v.66, 1991.

NG, Nora; RUGER, Jennifer. Global Health Governance at Crossroads. Global Health Governance, v.3, n.2, 2011.

NUZZO, Jennifer B.; GRONVALL, Gigi K. Global health security closing the gaps in responding to infectious disease emergencies. Global Health Governance, v.IV, n.2, 2011.

O'MANIQUE, Colleen. The "Securitisation" of HIV/AIDS in Sub-Saharan Africa: A Critical Feminist Lens. In: MACLEAN, Sandra J.; BLACK, David R.; SHAW, Timothy M. (orgs.). A Decade of Human Security: Global Governance and the New Multilateralisms. Ashgate Publishing, 2006.

OTTERSEN et al. The political origins of health inequity. Lancet, 2014. Disponível em: <http://dx.doi.org/10.1016/S0140-6736(13)62407-1>. Acesso em: junho 2014.

PANG et al. The new age of global health governance holds promise. Nature Medicine, v.16, n.11, 2010.

PATTBERG, Phillip. Global Governance: Reconstructing a Contested Social Science Concept. GARNET Working Paper, n.04/06, marco, 2006.

PBS. Interview - $\quad$ Kanatjan Alibekov. 2014. Disponível em: <http://www.pbs.org/wgbh/pages/frontline/shows/plague/interviews/alibekov.html>. Acesso em: 24 out. 2014. 
PEREIRA, Ricardo. Processes of Securitization of Infectious Diseases and Western Hegemonic Power: A Historical-Political Analysis. Global Health Governance, v.II, n.1, 2008.

PERTERSON, Susan. Epidemic disease and national security. Security Studies, v.12, n.2, 2002.

PIERRE, Jon. Introduction: Understanding Governance. In: PIERRE, Jon (org.). Debating Governance. Oxford: Oxford University Press, 2000.

PLOTKIN, B. Human rights and other provisions in the revised International Health Regulations (2005). Journal of the Royal Institute of Public Health, v.121, 2007.

PLOTKIN, B. KIMBALL, A. Designing an International Policy and Legal Framework for the Control of Emerging Infectious Diseases: First Steps. Emerging Infectious Diseases, v.3, n.1, 1997.

PRESCOTT, E. M. The Politics of Disease: Governance and Emerging Infections. Global health governance, v.1, n.1, 2007.

PRICE-SMITH, Andrew T. Contagion and Chaos: disease, ecology, and national security in the era of globalization. MIT Press, 2009.

PRICE-SMITH, Andrew T. Ghosts of Kigali: Infectious Disease and Global Stability at the Turn of the Century. International Journal, v. 54, n. 3, 1999.

PRICE-SMITH, Andrew T. The Health of Nations: infectious disease, environmental change and their effects on national security and development. MIT Press, 2002.

RADKE, E. et al. Dengue outbreak in Key West, Florida, USA, 2009. Emerging Infectious Diseases, v.18, n.1, 2012.

RAVISHANKAR, Nirmala et al. Financing of global health: tracking development assistance for health from 1990 to 2007. Lancet, v.373, 2009.

REITER, Dan. Preventive attacks against nuclear, biological and chemical weapons programs. In: KELLER, W.W.; MITCHELL, Gordon R (eds.). Hitting First: Preventive Force in U.S. Security Strategy. Pittsburgh: University of Pittsburgh Press, 2006.

RHODES, R. A. W. The New Governance: Governing without Government. Political Studies, v.XLIV, 1996.

RICCI, James. Global Health Governance and the State: Premature Claims of A PostInternational Framework. Global health governance, v.3, n.1, 2009.

RICHTER, Judith. Public-private partnerships and health for all how can who safeguard public interests. 2004. Disponível em: 〈http://www.ibfan.org/art/538-5.pdf>. Acesso em: 30 out. 2014. 
ROSEBURY, Theodor. Peace or Pestilence: biological warfare and how to avoid it. Nova Iorque: Whittlesey, 1946.

ROSENAU, James. Governance in a New Global Order. In: HELD, David; MCGREW, Anthony. The global Transformations Reader: An Introduction to the Globalization Debate. Cambridge: Polity Press, 2000.

ROSENAU, James. Governance in the Twenty-first Century. Global Governance, v. 1, n. 1, 1995.

ROSENAU, James. Governance, order and change in world politics. In: ROSENAU, James; CZEMPIEL, Ernst-Otto (org.) Governance without government: order and change in world politics. Cambridge: Cambridge University Press, 1992.

ROWDEN, R. The Deadly Ideas of Neoliberalism: How the IMF has Undermined Public Health and the Fight against AIDS. London: Zed Books; 2009.

RUCKERT A.; LABONTE, R. The financial crisis and global health: the International Monetary Fund's policy response. Health Promot Int, v.28, n.3, 2013.

RUGER, J. The changing role of the World Bank in global health. Am J Public Health, v.95, n.1, 2005.

RUGER, Jennifer P. Global heatlh governance as shared health governance. J Epidemiol Community Health, v.66, 2012.

RYAN, F. The forgotten plague: how the battle against tuberculosis was won - and lost. Boston, Little, Brown, 1993.

SANDBERG, K. I. et al. A new approach to global institutions a case study of new vaccine introduction and the formation of the GAVI alliance. Social Science and Medicine, v.71, 2010.

SATCHER, David. Emerging Infections: Getting Ahead of the Curve. Emerging Infectious Diseases, v.1, n.1, 1995.

SAXENIAN, Helen et al. An Analysis Of How The GAVI Alliance And Low- And MiddleIncome Countries Can Share Costs Of New Vaccines. Health Affairs, v.30, n.6, 2011.

SCUTTI, Susan. The Only Thing Scarier Than Bio-Warfare is the Antidote. 2014. Disponível em: <http://www.newsweek.com/2014/03/21/only-thing-scarier-bio-warfareantidote-247993.html>. Acesso em: 24 out. 2014.

SEN, Amartya. Why Human Security? In: International Symposium on Human Security, Tokyo, 2000.

SHAH, Saeed. CIA organised fake vaccination drive to get Osama bin Laden's family DNA. 2011. Disponível em: <http://www.theguardian.com/world/2011/jul/11/cia-fakevaccinations-osama-bin-ladens-dna>. Acesso em: 23 out. 2014. 
SHANE, Scott. Bioshield Effort Is Inadequate, a Study Says. 2004. Disponível em: <http://www.nytimes.com/2004/10/15/politics/15biosheild.html?_r=0>. Acesso em: 24 out. 2014.

SHIFFMAN, J. Donor funding priorities for communicable disease control in the developing world. In: GLOBAL FORUM FOR HEALTH RESEARCH. Monitoring Financial Flows for Health Research 2007. Geneva: Global Forum for Health Research, 2007.

SIMPSON, Ericka. The poor man's nuclear bomb. QMI Agency, 2014.

SINGER, Peter W. AIDS and international security. Survival, v.44, n.1, 2002.

SMITH, Kimberly. Statistical reporting by the Bill \& Melinda Gates Foundation to the OECD DAC. 2011. Disponível em: <http://www.oecd.org/dac/47539494.pdf>. Acesso em: 29 out. 2014.

SMOUTS, Marie-Claude. The proper use of governance in international relations. International Social Science Journal, v.50, n.155, março, 1998.

SPARKE, Matthew; ANGUELOV, Dimitar. H1N1, globalization and the epidemiology of inequality. Health \& Place, v.18, 2012.

SPENCER, Robert. Pakistan: More polio cases if resistance continues; Islamic clerics say those who die of polio are 'martyrs'.2007. Disponível em: <http://www.jihadwatch.org/2007/02/pakistan-more-polio-cases-if-re...nce-continuesislamic-clerics-say-those-who-die-of-polio-are-mar/>. Acesso em: 23 out. 2014.

STEWART, K. et al. Values in Global Health Governance. In BENATAR, S.; BROCK, G. Global Health and Global Health Ethics. Cambridge: Cambridge University Press; 2011.

STOKER, Gerry. Governance as theory: five propositions. International Social Science Journal, v.50, n.155, março, 1998.

STOP TB PARTNERSHIP. About Us. 2014b. Disponível em: <http://www.stoptb. org/about/>. Acesso em: 30 out. 2014.

STOP TB PARTNERSHIP. Partners. 2014a. Disponível em: <http://www.stoptb .org/about/partners_landing.asp>. Acesso em: 29 out. 2014.

STRUCKLER, D. et al. Global Health Philanthropy and Institutional Relationships: How Should Conflicts of Interest Be Addressed? Plos Medicine, v.8. n.4, 2011.

TAUBENBERGER, Jeffery; MORENS, David. 1918 Influenza: the Mother of all Pandemics. Emerging Infectious Diseases, v.12, n.1, jan.2006.

THE GLOBAL FUND. Government Donors. 2014. Disponível em: <http://www.theglobalfund.org/en/partners/governments/>. Acesso em: 29 out. 2014.

THE GLOBAL POLIO ERRADICATION INITIATIVE. About us. 2010. Disponível em: <http://www.polioeradication.org/AboutUs.aspx>. Acesso em: 30 out. 2014. 
THUCYDIDES. The Peloponnesian War. New York: Oxford, 2009.

TIGERSTROM, B. The Revised International Health Regulations and Restraint of National Health Measures. Health Law Journal, v.13, 2005.

TUCKER, Jonathan B. Breaking the deadlock over destruction of the smallpox virus stocks. Biosecurity and Bioterrorism: Biodefense Strategy, Practice, and Science, v.9, n.1, 2011.

TUCKER, Jonathan B. Breaking the Deadlock Over Destruction of the Smallpox Virus Stocks. Biosecurity and Bioterrorism: biodefense strategy, practice and science, v.9, n.1, 2011.

TUCKER, Jonathan B. Updating the International Health Regulations. Biosecurity and bioterrorism: biodefense, strategy, practice and science, v.3, n.4, 2005.

ULLMAN, Richard H. Redefining Security. International Security, v.8, n1, p.129-153, Summer 1983.

UNICEF. Kabul agrees to cease-fire for polio vaccination. 2000. Disponível em: <http://www.unicef.org/newsline/00pr33.htm>. Acesso em: 23 out. 2014.

UNITED NATIONS DEVELOPMENT PROGRAMME. Human development report. New York: Oxford University Press, 1994.

UNITED NATIONS NEWS CENTER. UN Security Council weighing how to enable Sudan's polio campaign, says president. 2013. Disponível em: <http://www.un.org/apps/news/story.asp/html/story.asp?NewsID=46469\&Cr=polio\&Cr1;=\#. UyM9kT9dUus>. Acesso em: 23 out. 2014.

UNITED NATIONS OFFICE AT GENEVA. What Are Biological and Toxin Weapons? 2014. Disponível em: <http://www.unog.ch/80256EE600585943 /(httpPages)/29B727532FECBE96C12571860035A6DB?OpenDocument>. Acesso em: 24 out. 2014.

UNITED STATES GOVERNMENT ACCOUNTABILITY OFFICE. High-Containment Laboratories: Assessment of the Nation's Need Is Missing. Washington, 2013.

UNITES NATIONS SECURITY COUNCIL. Resolution 1983. 2011. Disponível em: <http://www.unaids.org/en/media/unaids/contentassets/documents/document/2011/unsc/2011 0607_unsc-resolution1983.pdf> Acesso em: 15 de novembro de 2013.

US DEPARTMENT OF HEALTH AND HUMAN SERVICES. Assistant Secretary Nicole Lurie statement on the Pandemic and All Hazards Preparedness Reauthorization Act. 2013. Disponível em: <http://www.hhs.gov/news/press/ 2013pres/03/20130313a.html>. Acesso em: 24 out. 2014.

VALLAT, Bernard. A World United Against Infectious Diseases: Cross-Sectoral Solutions. 2013. Disponível em: <http://www.oie.int/fileadmin/Home/eng/Media 
Center/docs/pdf/Key_Documents/Speech_BV_PMAC_V2_Final_1_.pdf>. Acesso em: 29 out.2014.

WAEVER, Ole. Securitization and Desecuritization. In: LIPSCHULTZ, Ronnie D. (org.). On Security. New York: Columbia University Press, 1995.

WAEVER, Ole. The EU as a Security Actor: Reflections from a Pessimistic Constructivist on Post-Sovereign Security Orders. In: KELSTRUP, M.; WILLIAMS, M.C. International Relations Theory and the Politics of European Integration. Londres: Routledge, 2000.

WALD, P. Contagious: cultures, carriers, and the outbreak narrative. Durham: Duke University Press, 2007

WALSH, Declan. Taliban Block Vaccinations in Pakistan. 2012. Disponível em: <http://www.nytimes.com/2012/06/19/world/asia/taliban-block-vaccinations-inpakistan.html>. Acesso em: 23 out. 2014.

WALT, Stephen M. The Renaissance of Security Studies. International Studies Quarterly, v. 35, n. 2, 1991.

WALTZ, Kenneth N. Theory of International Politics. New York: McGraw Hill, 1979.

WENDT, Alexander. Social theory of international politics. Cambridge University Press, 1999.

WHITE HOUSE. Fact sheet: Global War on Terror. 2014. Disponível em: < http://georgewbush-whitehouse.archives.gov/infocus/bushrecord/factsheets/9-11.html >. Acessado em: marco de 2014

WHITE HOUSE. President Bush Signs Project Bioshield Act of 2004. 2004. Disponível em: <http://georgewbush-whitehouse.archives.gov/news/releases/2004/07/20040721-2.html>.

Acesso em: 24 out. 2014.

WHITE HOUSE. The National Security Strategy of the United States of America. 2002.

WILSON, K. et al. Strategies for implementing the new International Health Regulations in federal countries. Bulletin of the World Health Organization, v.86, 2008.

WILSON, K. et al. The New International Health Regulations and the Federalism Dilemma. Plos Medicine, v.3, n.1, 2006.

WOOLHOUSE, Mark; GAUNT, Eleanor. Ecological Origins of novel human pathogens. Critical Reviews in Microbiology, v.33, n.231, 2007.

WORLD HEALTH ORGANIZATION. Action to stop polio now in Nigeria, Pakistan and Afghanistan. Genebra: World Health Organization, 2012a.

WORLD HEALTH ORGANIZATION. Alert, response, and capacity building under the International Health Regulations (IHR). 2014e. Disponível em: <http://www.who.int/ihr/about/en/>. Acesso em: 29 out. 2014. 
WORLD HEALTH ORGANIZATION. Bioterrorism and Military Health Risks. 2003d. Disponível em: <http://www.who.int/dg/brundtland/speeches/2003/DAVOS/en/>. Acesso em: 24 out. 2014.

WORLD HEALTH ORGANIZATION. Cholera outbreak - assessing the outbreak response and improving preparedness. Genebra: WHO, 2004b.

WORLD HEALTH ORGANIZATION. Cholera - The Global Task Force on Cholera Control. 2014f. Disponível em: <http://www.who.int/cholera/introduction/en/>. Acesso em: 31 out. 2014.

WORLD HEALTH ORGANIZATION. Communicable diseases prevention and control: new, emerging, and re-emerging infectious diseases. WHA48.13. 1995a.

WORLD HEALTH ORGANIZATION. Constitution of the World Health Organization. 1946. Disponível em: <http://apps.who.int/gb/bd/PDF/bd47/EN/constitution-en.pdf?ua=1>. Acesso em: 31 out. 2014.

WORLD HEALTH ORGANIZATION. Dengue: guidelines for diagnosis, treatment, prevention and control. Genebra: WHO, 2009b.

WORLD HEALTH ORGANIZATION. Ebola virus disease - Fact sheet n.103. 2014b. Disponível em: <http://www.who.int/mediacentre/factsheets/fs103/en/>. Acesso em: 03 nov. 2014.

WORLD HEALTH ORGANIZATION. Emergency response framework (ERF). Genebra: WHO, 2013c.

WORLD HEALTH ORGANIZATION. Emerging and re-emerging infectious diseases Fact sheet n.97. 1998. Disponível em: <www.who.int/inf-fs/en/fact097.html>. Acesso em: 31 out. 2014.

WORLD HEALTH ORGANIZATION. Frequently asked questions about the International Health Regulations (2005). 2009a. Disponível em: <http://www.who.int/ihr/about/FAQ2009.pdf>. Acesso em: 31 out. 2014.

WORLD HEALTH ORGANIZATION. Global Crises - Global Solutions Managing public health emergencies of international concern through the revised International Health Regulations. WHO/CDS/CSR/GAR/2002.4. 2002. Disponível em: <http://www.who.int/csr/resources/publications/ihr/WHO_CDS_CSR _GAR_2002_4_EN/en/>. Acesso em: 31 out. 2014.

WORLD HEALTH ORGANIZATION. Global defense against the infectious disease threat. Genebra: WHO, 2003c.

WORLD HEALTH ORGANIZATION. Global health security: epidemic alert and response. WHA54.14. $2001 \mathrm{~b}$. 
WORLD HEALTH ORGANIZATION. Global health security - epidemic alert and response. A54/9. 2001a. Disponível em: <http://apps.who.int/medicinedocs/documents /s16357e/s16357e.pdf>. Acesso em: 31 out. 2014.

WORLD HEALTH ORGANIZATION. Global pandemic influenza action plan to increase vaccine supply. Genebra: WHO, 2006.

WORLD HEALTH ORGANIZATION. Global tuberculosis report 2013. Genebra: WHO, $2013 b$.

WORLD HEALTH ORGANIZATION. Ground zero in Guinea: the outbreak smoulders undetected - for more than 3 months. 2014a. Disponível em: <http://www.who.int/csr/disease/ebola/ebola-6-months/guinea/en/>. Acesso em: 03 nov. 2014.

WORLD HEALTH ORGANIZATION. International Health Regulations (1969). Genebra: WHO, 1983.

WORLD HEALTH ORGANIZATION. International Health Regulations (2005). Genebra: WHO, 2006.

WORLD HEALTH ORGANIZATION. Pandemic influenza preparedness framework for the sharing of influenza viruses and access to vaccines and other benefits. Genebra: WHO, 2011. Disponível em: <http://apps.who.int/gb/pip/>. Acesso em: 31 out. 2014.

WORLD HEALTH ORGANIZATION. Pandemic (H1N1) 2009 guidance documents. 2014d. Disponível em: <http://www.who.int/csr/resources/publications/ swineflu/en/>. Acesso em: 03 nov. 2014.

WORLD HEALTH ORGANIZATION. Poliomyelitis - Fact sheet n.114. 2013a. Disponível em: <http://www.who.int/mediacentre/factsheets/fs114/en/>. Acesso em: 31 out. 2014.

WORLD HEALTH ORGANIZATION. Protocol for Assessing National Surveillance and Response Capacities for the International Health Regulations (2005). WHO/HSE/IHR/2010.7. Genebra: WHO, 2010. Disponível em: <http://www.who.int/ihr/publications/who_hse_ihr_201007/en/>. Acesso em: 31 out. 2014.

WORLD HEALTH ORGANIZATION. Revision and updating of the International Health Regulations. WHA48.7. 1995b.

WORLD HEALTH ORGANIZATION. Revision of the International Health Regulations. WHA58.3. 2005.

WORLD HEALTH ORGANIZATION. Severe Acute Respiratory Syndrome (SARS) multi-country outbreak - Update 16.2003b. Disponível em: <http://www.who.int /csr/don/2003_04_01/en/>. Acesso em: 31 out. 2014.

WORLD HEALTH ORGANIZATION. Severe acute respiratory syndrome (SARS). WHA56.29. 2003e. Disponível em: <http://www.who.int/csr/sars/en/ea56r29.pdf>. Acesso em: 24 out. 2014. 
WORLD HEALTH ORGANIZATION. Social determinants of health - What are social determinants of health? 2014g. Disponível em: <http://www.who.int/social _determinants/sdh_definition/en/>. Acesso em: 31 out. 2014.

WORLD HEALTH ORGANIZATION. Summary of probable SARS cases with onset of illness from 1 November 2002 to 31 July 2003. 2014c. Disponível em: <http://www.who.int/csr/sars/country/table2004_04_21/en/>. Acesso em: 03 nov. 2014.

WORLD HEALTH ORGANIZATION. WHO SARS Risk Assessment and Preparedness Framework - WHO/CDS/CSR/ARO/2004.2. 2004c. Disponível em: <http://www.who.int/csr/resources/publications/CDS_CSR_ARO_2004_2.pdf >. Acesso em: 31 out. 2014.

WORLD TRADE ORGANIZATION. The WTO Agreement on the Application of Sanitary and Phytosanitary Measures (SPS Agreement). 2014. Disponível em: <http://www.wto.org/english/tratop_e/sps_e/spsagr_e.htm>. Acesso em: 29 out. 2014.

WORLD TRADE ORGANIZATION. WTO Agreements and Public Health. 2002. Disponível em: <http://www.wto.org/english/res_e/booksp_e/who_wto_e.pdf>. Acesso em: 29 out. 2014.

YANG, J.; MCDANIEL, P.'A question of balance': Addressing the public health impacts of multinational enterprises in the OECD Guidelines for Multinational Enterprises. Glob Public Health, v.7, n.10, 2012.

YOUDE, Jeremy. Enter the Fourth Horseman: Health Security and International Relations Theory. Whitehead J. Dipl. \& Int'l Rel, v.193, n.6, 2005.

YOUDE, Jeremy. Mediating Risk through the International Health Regulations and Biopolitical Surveillance. Political Studies, v.59, 2011.

YOUNG, Oran R. Governance in World Affairs. Ithaca: Cornell University Press, 1999.

YOUNG, Oran. International Regimes: problems of concept formation. World Politics, v.32, n.3, 1980 .

ZACHER, Mark. The decaying pillars of the Westphalian temple: implications for international order and governance. In: ROSENAU, James; CZEMPIEL, Ernst-Otto (org.) Governance without government: order and change in world politics. Cambridge: Cambridge University Press, 1992.

ZACHER, Mark. The transformation in globalhealth collaboration since the 1990s. In: COOPER, A. et al. (eds.) Governing global health: challenge, response, innovation. Aldershot: Ashgate, 2007.

ZHANG, Ying et al. Did Advances in Global Surveillance and Notification Systems Make a Difference in the 2009 H1N1 Pandemic? - a retrospective analysis. Plos One, v.8, n.4, 2013. 
